Portland State University

PDXScholar

5-10-1996

\title{
An Analysis of Japanese Learners' Comprehension of Intonation in English
}

Misako Okubo

Portland State University

Follow this and additional works at: https://pdxscholar.library.pdx.edu/open_access_etds

Part of the Bilingual, Multilingual, and Multicultural Education Commons Let us know how access to this document benefits you.

\section{Recommended Citation}

Okubo, Misako, "An Analysis of Japanese Learners' Comprehension of Intonation in English" (1996). Dissertations and Theses. Paper 5172.

https://doi.org/10.15760/etd.7048

This Thesis is brought to you for free and open access. It has been accepted for inclusion in Dissertations and Theses by an authorized administrator of PDXScholar. Please contact us if we can make this document more accessible: pdxscholar@pdx.edu. 


\section{THESIS APPROVAL}

The abstract and thesis of Misako Okubo for the Master of Arts in TESOL were presented May 10, 1996, and accepted by the thesis committee and the department.

COMMITTEE APPROVALS:

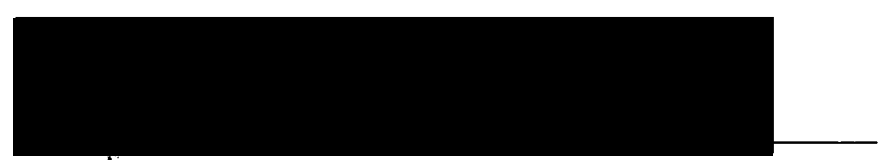

Jeanjette DeCarrico, Chair

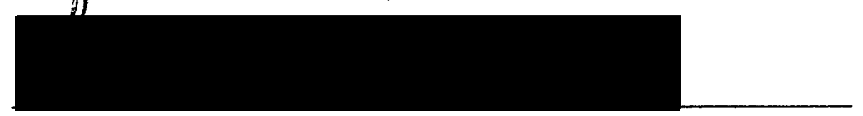

Beatrice Oshika

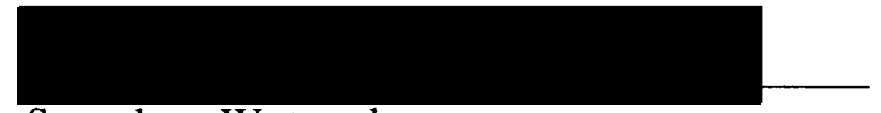

Suwako Watanabe

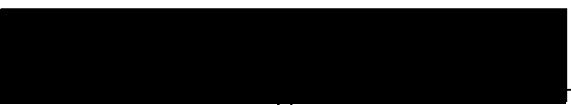

Patricia Wetzel

Representative of the Office of Graduate Studies

DEPARTMENT APPROVAL:

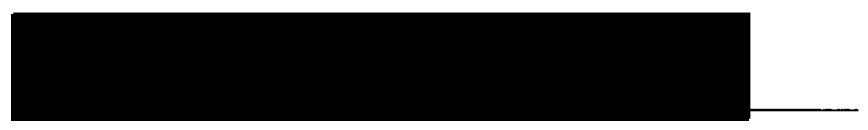

Beatrice Oshika

Department of Applied Linguistics

$* * * * * * * * * * * * * * * * * * * * * * * * * * * * * * * * * * * * * * * * * * * * * * * * * * * * * * * * * * * * * * * * * * * * * * * * *$

ACCEPTED FOR PORTLAND STATE UNIVERSITY BY THE LIBRARY b y

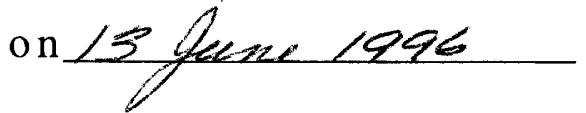




\section{ABSTRACT}

An abstract of the thesis of Misako Okubo for the Master of Arts of TESOL presented May 10, 1996.

Title: An Analysis of Japanese Learners' Comprehension of Intonation in English.

Typically, most native speakers of Japanese, who have been taught English in Japan, have had limited exposure to prosodic features of English. Consequently, their ability to understand the meaning of different intonation patterns is limited as well. Though it is generally accepted that intonation plays a crucial role in English communication, comprehensive pedagogical materials for teaching English intonation to native speakers of Japanese are not widely available or used in Japan. This is, in part, due to the complexity of English prosodic features and their abstractness. A better understanding of these barriers requires that the extent and the nature of native speakers of Japanese' understanding of English intonation be explored.

The scope of this study is restricted to the examination of the following questions: (1) How well, compared with native speakers of English, can Japanese adult learners comprehend intonation patterns of English? (2) Are there any patterns in their misinterpretations of 
test sentences, according to three types of errors: paraphrase, categorization, or attitudinal judgments? (3) Can Japanese learners who comprehend one variation of intonation also interpret correctly the same sentence with the contrastive variation of intonation?

Seventy-four native speakers of Japanese and thirty-one native speakers of English (control group) listened to twenty pairs of sentences presented with contrastive intonation. For each sentence they were asked to choose one of three different interpretations. Their responses were evaluated, at a 0.05 level of significance, using statistical tests of hypothesis ( $\mathrm{t}$ and chi-square), and measures of correlation (r, phi and Cramers's V).

Major findings of this study are (1) the Japanese students had more difficulty with comprehending English intonation than the American students; (2) the Japanese students seemed to lack knowledge of grammar-intonation relationships; (3) they were able to understand attitudinal judgment intonation as well as native speakers. 


\section{AN ANALYSIS OF JAPANESE LEARNERS' COMPREHENSION OF INTONATION IN ENGLISH}

b y

MISAKO OKUBO

A thesis submitted in partial fulfillment of the requirements for the degree of

\section{MASTER OF ARTS}

in

TESOL

Portland State University

1996 


\section{ACKNOWLEDGMENTS}

I would like to thank all the students who participated in this research project. I am most grateful to Jeanette DeCarrico, who was involved in every step of this study. I would particularly like to note my appreciation to Beatrice Oshika and Suwako Watanabe for their support and guidance, and especially to Wes Brenner for his time and patience in helping me with my statistical analysis. I owe an enormous debt of gratitude to David Hansen for all his help and encouragement. Finally, I wish to thank my parents and Jun Komatsu for their support and patience. 


\section{TABLE OF CONTENTS}

\section{PAGE}

ACKNOWLEDGEMENTS ii

LIST OF TABLES vii

LIST OF FIGURES . viii

\section{CHAPTER}

Background

Key Definitions.

Statement of Research Questions............................... 9

I I REVIEW OF RELATED LITERATURE..................................... 11

What is Intonation?................................................... 11

Supersegmental Aspect of Phonetics

Function of Intonation

Theoretical Background

Sources of Difficulties in English Prosody........... 16

Evidence That the Meaning of

Supersegmentals are Not Universal

Teaching English in Japan

Analysis of English and Japanese Intonation Systems

Similarities Between English and Japanese Intonational Systems

Differences Between English and Japanese Intonational Systems 
Pedagogical Views for Acquisition of Intonation

Teaching Techniques for Supersegmentals

Learner's Self-involvement and Teacher

Involvement

Integrated Approaches to Teaching Oral

Communication Skills

Summary

I I I METHOD AND PROCEDURE ............................................... 33

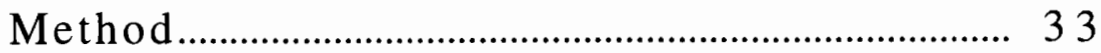

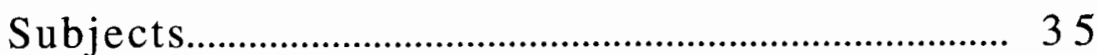

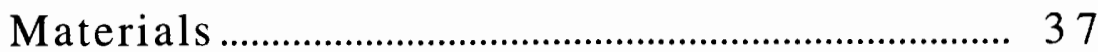

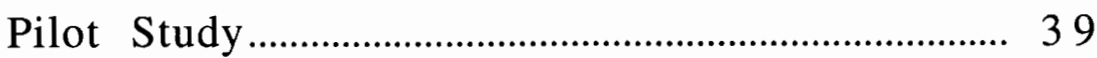

Procedures............................................................. 40

Data Collection

Test Explanation and Instruction

Data Analysis............................................................... 42

Questions to be Analyzed

Analysis by Different Proficiencies

in English

Types of Intonation

Evaluating Contrastive Variations of

Intonation

Summary

46

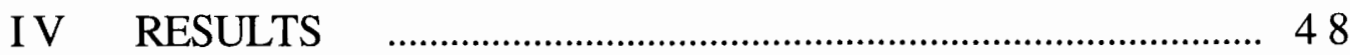

Procedure

Results .......................................................................... 49

Overall Performance of the Intonation

Test by Japanese Subjects

Analysis of $70 \%$ Validity Threshold

Subset 
Analysis of $80 \%$ Validity Threshold Subset

Types of Intonation

Contrastive Variations of Intonation

Analysis of Other Potential Variables

on Japanese Subjects

Summary of Results

Validity of the Test

Potential Test Variables

Specific Examples of Americans' Poor

Performance

Japanese Learners' Ability of

Comprehending Intonation

How Well Do Japanese Understand

English Intonation?

Performance on Contrastive

Variations

Difficulties Due to Insufficient

Grammatical Knowledge

Strengths and Weaknesses of Japanese

Students

Performance Relative to Intonation

Pattern

The Transfer Strategy

The Pitch Height Strategy

The Lexico-syntactic Strategy

Exceptions

The Effect of Different ESL Levels.......................... 102

More Advanced, More Competent?

Influence of Different ESL

Levels on Attitudinal Judgments

Causes of Difficulty 
Descriptions of Intonation in Japanese

Workbooks and Dictionaries

The Importance of Comprehensible

Input

Summary

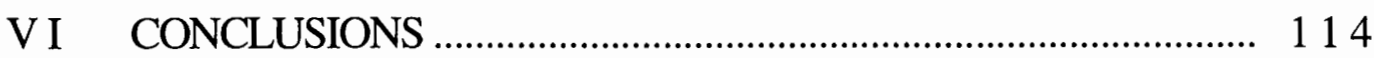

Research Implications .............................................. 114

Conclusions

Limitations of the Study

Suggestions for Further Research

Pedagogical Implications.

Need for Comprehensible Input

Conscious Attention to

Supersegmentals

Self-correct and Self-monitor

REFERENCES

126

APPENDICES

A COMPREHENSION TEST OF INTONATION

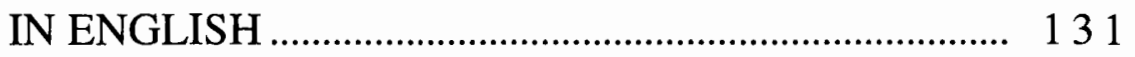

B RESPONSES TO COMPREHENSION TEST IN

JAPANESE............................................................. 139

C SURVEY SHEET ……............................................... 145

D LIST OF JAPANESE SUBJECTS................................... 147

E CORRECT, APPROPRIATELY WRONG AND

WRONG RESPONSES BY SUBJECT GROUP 


\section{LIST OF TABLES}

TABLE

PAGE

I Percentages of Correct Answers for Each

Question by American Subjects.......................................... 41

I I Descriptive Statistical Summary ……….............................. 50

II I Descriptive Statitical Summary by Type of

Intonation (Paraphrase)....................................................... 56

IV Propotion of Correct Responses by Each

Contrastive Variation Pair (Paraphrase)......................... 64

V Propotion of Correct Responses by Each

Contrastive Variation Pair (Categorization) ..................... 66

VI Propotion of Correct Responses by Each

Contrastive Variation Pair

(Attitudinal Judgments) ........................................................ 67

VII Descriptive Statistical Summary

Percent Correct or Approriately Wrong ........................... 70 


\section{LIST OF FIGURES}

1. Score Distribution of Correct Answers by

Each Group

2. Score Distribution in the $70 \%$ Threshold by

Each Group.

3. Score Distribution in the $80 \%$ Threshold by

Each Group.

4. Score Distribution by Intonation Type

(Paraphrase) of Each Group

5. Score Distribution by Intonation Type

(Paraphrase) in the $70 \%$ Validity Threshold.

6. Score Distribution by Intonation Type

(Paraphrase) in the 80\% Validity Threshold.................. 58

7. Score Distribution by Intonation Type

(Categorization)

8. Score Distribution by Intonation Type

(Categorization) in the $70 \%$ and $80 \%$

Thresholds

9. Score Distribution by Intonation Type

(Attitudinal Judgements).

10. Score Distribution of Correct and Appropriately Wrong Asnwers. 


\section{CHAPTER I}

\section{INTRODUCTION}

The present study attempts to deal with Japanese learners' comprehension of intonational meaning in utterances. The main purpose of the study is (1) to determine the Japanese learners' difficulties in comprehending English intonation, and (2) to understand where the problems lie. A comprehension test of intonation is used for Japanese learners of English and its results are analyzed to see whether or not they have systematic error patterns. Based on the findings of this analysis, pedagogical implications are discussed.

\section{BACKGROUND}

Generally speaking, the utterances of non-native speakers almost always reveal some traits of the native language. Although it is still difficult to understand how native language and target language interact with each other in the process of interlanguage (IL), a better understanding is required in teaching pronunciation. More specifically, the importance of intonation in English should not be underestimated. Some researchers suggest that appropriate intonation is more essential for intelligibility than correct individual 
sound units (see for example, Pike, 1945; Fries, 1945). Despite this concern, traditional pronunciation teaching which focuses on sound discrimination is still a substantial component of modern classrooms (see for example, Morley, 1991). As a result, teaching prosodic features of English tends to be ignored. Even advanced students have difficulty in comprehending and employing proper intonation. Thus, a lack of pedagogical aid makes it difficult for learners of English to attain native-like prosody.

Intonation plays a crucial role for communication in English since two sentences identical on the surface level may have two different meanings depending on intonation, whereas generally vocabulary or particles play such a role in Japanese. Despite the fact that Japanese students need to know the roles of English intonation, there is reluctance to teach it is because of the difficulty of its instruction. Unlike articulation for phonemes, the features of intonation, due to their abstractness, are difficult to explain and establish in one concrete theory. Crystal (1969) claims that the unclear descriptions of prosodic patterns in a number of teaching materials stem from the fact that a well-defined theory for intonation does not exist. Some researchers, such as Liberman and Sag (1974), Sag and Liberman (1975), Ladd (1977), and Liberman (1978) have attempted to describe theories of intonation which imply intonational meanings do not necessarily link with syntax. Furthermore, Goldsmith (1990) claims that autosegemental and metrical phonology are more powerful than classical generative phonology. Even so, one cannot avoid facing problems in the formal 
description since the range of each pitch-phoneme is approximately depicted. It is inevitable that such a range varies from speaker to speaker, or even with one speaker in different circumstances (see Cruttenden, 1980; Crystal, 1969).

One of the major problems in discussion of intonation is the somewhat interchangeable use of the terms pitch, tone, and stress. For the purposes of this thesis, these are the terms to be used and their acoustic definition:

- pitch is fundamental frequency (i.e., frequency of vibration of the vocal folds)

- loudness is amplitude (i.e., energy)

- duration is time.

The use of other terms such as tone, stress, and intonation will be used only to describe linguistic patterns of pitch, loudness, and duration as they might be used in Japanese or English. Japanese stress and intonation manipulate primarily pitch and duration. English stress and intonation represent the complex interaction of all three features of pitch, loudness and duration. Therefore, Japanese learners of English require intonation instruction that illuminates the difference between the two systems.

More generally, English education in Japan should introduce pronunciation-focused instruction since a new subject, "oral communication" in English, has been practiced since April, 1994. Due to this shift, the Center of University Entrance Examinations is planning to adopt a listening comprehension test in 1997 (Homma, 1994). As the emphasis on oral skills is rising year by year, the 
pedagogical approach to intonation instruction should be revised. Therefore, it is necessary to examine both Japanese and English intonation pattern so as to understand what hinders Japanese students from correctly learning English prosody in the second language acquisition.

Because of the inadequacy of existing theoretical frameworks, the intonational aspect of communication tends to be forgotten in terms of pedagogy. Consequently, recent studies investigating intonation reveal that even advanced language learners have trouble with supersegmentals in both perception and production.

With regard to perception, Cruz-Ferreira (1987) and Luthy (1983) support the evidence that non-native speakers have difficulty interpreting the intonation patterns of the second language. Likewise, a number of researchers (for example, Teaman, 1992; Lepetit, 1989; Okumura, 1979) argue that intonation is a significant indicator of a foreign accent in production. Researchers, such as CruzFerreira (1987), Lepetit (1989), and Okumura (1979), claim that learners' first language (L1) influences their intonation in the second language (L2). Furthermore, they imply that it is possible to predict typical non-native judgments on intonational meaning or production for each native language. If so, in order to devise the most effective teaching methods for each native language group, it is necessary to understand both L1 and L2 intonational systems. In the present study, English and Japanese intonational systems will be examined. To analyze Japanese students' problematic intonation pattern in English, a comprehension test developed by Cruz-Ferreira (1989) will 
be used in this study. Based on her study of native speakers of both Portuguese and English (1987), she developed a test for non-native comprehension of intonation in English. Although the present study is not a replication of her study, this test will be used and her suggestions for test procedure will be taken into consideration. As Cruz-Ferreira points out, the reason for focusing on comprehension is that the first difficulty with L2 intonation encountered by non-native speakers presumably exists in comprehension, not in production. With regard to phonemes, some researchers (see for example, Sheldon and Strange, 1982; Brière, 1966) claim that speech production can precede speech perception. However, this conclusion is inapplicable to the argument that correct production of intonation precedes the perception. This is because in intonation only one articulatory basis, vocal cord vibration, is employed while phonemes are involved with a number of variables acting as articulatory bases. Faulty intonation patterns might be also due to lack of knowledge of appropriate intonation usage. Comprehension thus seems to account for learner's real difficulties in L2 intonation.

Another reason for examining comprehension in intonation is that little research has been focused on this issue for Japanese learners of English (Watanabe, 1994). Only recently has intonation started to draw attention in second language acquisition, and there is not much previous experimental data available in this field. Although some studies considering the intonational production of Japanese speakers of English were conducted by several researchers (Teaman, 1992, Okumura, 1979), comprehension abilities are still 
largely unexplored. Hence, in order to determine the intonational competence of Japanese speakers of English, it is essential to examine it in comprehension.

\section{KEY DEFINITIONS}

In the present study, what is meant by English is "Standard American English", which is a variety of spoken American English used in school language instruction, network radio, and television newscasts.

The symbols used to represent intonation in the test sentences are adopted from O'Connor and Arnold (1973) as follows:

a falling tone
$\checkmark \quad$ a rising tone
$\wedge \quad$ a fall-rise tone
$/ \quad$ intonation group boundary

High variants are located at the top of the sentence and low variants at the bottom.

In the test, three types of intonational choice (see Halliday, 1967) are taken into consideration:

Tonality the division of an utterance into intonation groups

Tonicity the placement of the nucleus, or main accent, in each intonation group 
Tone the melodic shape of the nucleus, e.g., rising or falling

As Cruz-Ferreira (1989) cited examples, there can be two kinds of intonational uses, general and local, depending on each of the three choices:

General conveying differences of meaning occurring in other languages

Local conveying differences of meaning which are specific to English

The following examples are excerpted from Cruz-Ferreira's (1989) test samples:

I. Tonality

A different interpretation of a relative clause, that is, a restrictive versus non-restrictive, also exists in some other languages. Sentence (18) implies that there are other children who were not playing whereas (38) does not.

general - the differences between

(38) the ,children/ who were playing/ looked unhappy and

(18) the children who were playing looked unhappy

The interpretation of the verb dress as an intransitive versus transitive verb is because of the ambiguity of the verb in English. Sentence (4) means that it is she who dressed while (24) means that it is the baby who dressed. 
local - the difference between

(4) she dressed/ and fed the 'baby

and

(24) she dressed and fed the 'baby

II. Tonicity

Modifying the scope of the adverb also is a characteristic of some other languages too. Sentence (3) implies that there are some other people who translated the book whereas (23) implies that he did something else in addition to translating.

general - the difference between

(3) he also translated the book

and

(23) he also translated the book

Because of the ambiguity of might in English, the modal may be interpreted as either an unfulfilled duty on the part of "he" or as a possibility.

local - the difference between

(17) he might have told me

and

(37) he 'might have told me

III. Tone

Implying a surprised sentence (19) versus a neutral statement (39) also exists in some other languages. 
general - the difference between

(19) John passed his êxams

and

(39) John passed his èxams

Restricting or generalizing the scope of the negator ["only some types of coffee" (13) versus "no coffee at all"(33)] is unique to the interaction of negator and quantifier in these kinds of sentence in English.

local - the difference between

(13) she won't drinkªny coffee

and

(33) she won't drink àny coffee

\section{STATEMENT OF RESEARCH QUESTIONS}

There are many features that make English pronunciation difficult for Japanese speakers. Above all, intonation seems to be the last strong barrier of a foreign accent for learners of English. Intonation in pedagogy, however, has not been emphasized until lately. This is partly because of a lack of well-defined theoretical frameworks and partly because of the difficulty in teaching intonation. Rather, the focus of pronunciation teaching has been on phonemes. Since English education in Japan has held to the grammar translation method, Japanese students have great difficulty with English pronunciation, as well as intonation. In the researcher's own 
experience, intonation patterns have almost never been taught in Japan, although English has more complex patterns to highlight stressed words in context than Japanese. As a result, it is questionable whether or not they understand, as natives do, a subtle difference which changes the meaning of the utterance.

Thus, the scope of this study is to analyze identify errors in the case that the learners do not have a native like manipulation for intonation, to determine whether their misinterpretations are systematically conducted, and if so, what the characteristics are. This goal is expressed in the following research questions:

I. a. How well, compared with native speakers of English, can Japanese adult learners comprehend intonation patterns of English?

b. How do the different ESL levels in English affect their comprehension of intonation patterns?

II. Are there any patterns in their misinterpretations of test sentences, according to three types of errors: paraphrase, categorization, or attitudinal judgments (see Chapter III)?

III. Can Japanese learners who comprehend one variation of intonation also interpret correctly the same sentence with the contrastive variation of intonation? 


\section{CHAPTER II}

\section{REVIEW OF RELATED LITERATURE}

Related literature is reviewed to establish a premise for this study. First, what intonation means in the field of phonology is overviewed and its function and theoretical background are described. Second, what makes English prosody difficult for Japanese learners of English is discussed. A variety of studies which support the position that nonnative speakers have difficulty with intonation, and a discussion of methods of teaching English in Japan to Japanese students are presented. Third, English and Japanese intonational systems are analyzed, from the perspective of similarities and differences. Finally, pedagogical views for acquisition of intonation are discussed.

\section{WHAT IS INTONATION?}

\section{Supersegmental Aspect of Phonetics}

With respect to phonology, there are two necessary aspects of speech: segmentals and supersegmentals. The segmental system includes individual consonants and vowels, whereas the supersegmental system involves the consideration of more than single consonants, specifically, rhythm, stress, and intonation. Given the integral relationship of these characteristics, proper description 
of intonation requires that rhythm and stress be described first.

The rhythmic structure of language is classified into two categories: stress-timed languages and syllable-timed languages (see Pike, 1945). English belongs to the former, while other languages like French or Japanese, the latter. More precisely, in a stress-timed language, each group of phrases and sentences has the same basic kind of rhythm and moreover, the number of stressed syllables is normally the same, but each line adds at least one unstressed syllable. In other words, the syllables in a word or sentence are not equal in length or strength. On the other hand, in a syllable-timed language, each syllable is equally stressed and syllables follow each other at regular intervals.

Stress is manifested by pitch, duration, and loudness. The stressed syllable is usually pronounced longer, louder, and with higher pitch than the unstressed syllable. Furthermore, stress plays a crucial role in forming an intonation pattern.

Intonation is viewed as the melody of language (see for example, O'Connor, 1967, and Bolinger, 1986). The vibration of the vocal cords produce pitch which is the musical tone and a sequence of pitch movements during speech is usually called an intonation pattern. However, intonation is more complex interaction among pitch, rhythm and stress.

\section{Function of Intonation}

The traditional view of the function of intonation is that it conveys the speaker's emotions and attitudes toward his/her utterance. As Crystal (1969) points out, no linguists would disagree 
that this is indeed part of the role that intonation plays. However, many linguists have recently started to think that this function of intonation is not a primary concern of linguistic analysis. While recognizing its importance, the linguists suggest that the function of signaling the speaker's attitudes should be classified into paralinguistic features. Liberman (1967), for example, supports this view, proposing that "the effects of emotion" be "independent of the linguistic aspects of the speech signal" (1967:121). The reason for this is that one can recognize whether the utterance is a question or not regardless of the speaker's emotion. According to Crystal (1969), in order to reach the most accurate analysis of intonation, the following variables should be considered: other prosodic systems, paralinguistic systems, grammar and lexis, style of utterance, personal features, especially voice quality, kinetic features, other relevant situational features. Since any one of these variables can affect intonation contour, development of semantic description of prosodic features has been slow.

Linguists such as Bolinger (1951) and Uldall (1960) have drawn the conclusion that the basic molds for ordinary English utterances can be varied, depending on the individual. "There may be 'regular' intonation by the measure of statistical preponderance, but not in the sense of neutrality or absence of emotion" (Bolinger, 1951:205). "All of the supposed intellectual meanings assigned to intonation carry some kind of emotional tone" (Bolinger,1951:204). Uldall (1960) suggests that degrees of strength of attitude can be ranked although there exists no evidence for a "conventional neutral" 
contour for major sentence-types. Thus, it is difficult to differentiate a grammatical from a non-grammatical function.

As Gleason (1965) points out, "no adequate analysis will be possible until this discrimination can be made satisfactorily" (1965:79). Though recent work by Goldsmith (1990) and others has established a theoretical basis for such discrimination, well defined pedagogical applications are still lacking. Since the primary goal of the English learner should be to convey a message with applicable intonation patterns rather than to express emotions or attitudes through intonation, a concern over the equivalence of patterns and descriptive labels should be of elementary importance in the development of pedagogical applications consistent with current theory.

\section{Theoretical Background}

Before turning to the discussion of intonation in second language acquisition, a more general theoretical framework in this field should be provided in order to reach a better understanding. It is Bolinger (1989) who has brought the most powerful and specific arguments against the analysis of pitch-levels organized into phonemes or morphemes, or the analysis concerning functional units within pitch-contours. The main point of his argument is that prosodic features are so different from phonemes that the same methodology can not be applied to both. Many factors support this statement. Prosodic features are not as formally discontinuous as phonemic segments and the former overlap more than the latter. The range of an intonational articulation quite frequently varies in 
proportion to the degree of an emotional intensity, whereas segmental phonemes rarely do. In intonation only one articulatory basis, vocal cord vibration, is employed with duration and loudness, while phonemes are involved with a number of variables acting as articulatory bases.

Arguments also expand to the systems of pitch-level analysis. Due to the fact that none of the pitch-levels is clearly defined, one can expect inconsistency in their description. Since the range of each pitch-phoneme is approximate, it is inevitable that such a range varies from speaker to speaker, or even within one speaker on different circumstances (see Crystal, 1969). For this reason, one cannot rely on a four-level intonational system such as Pike (1945) proposed. Supporting Bolinger's criticism, Crystal (1969) notes that such earlier analyses are due to "the lack of empirical study of pitch contrasts from an adequate corpus of data to test the theory, and the similar lack of experimental investigation" (1969:199). As far as semantics is concerned, despite its importance, this pitch-phoneme theory simply excludes the formal description. Consequently, many linguists started exploring a new theory.

Liberman and Sag (1974) argue that intonation performs discourse functions. They also claim that semantics and the pragmatics of discourse function are other matters. Sag and Liberman (1975) explain one tune which they named surprise redundancy contour. The meaning of this tune is generally defined as interaction with the local pragmatics. Such a contour can be observed in a WH rhetorical question, which often implies a negative connotation. Ladd (1977) discusses the basic meaning of fall-rise, 
which will force certain syntactic judgments. For example, in the sentence "All the men didn't go" with the fall-rise intonation, "the logical relation of the negative and the focus is not part of the deep structure and is the result only of such lines of reasoning as 'all can't be a subset so it must mean not all"' (Ladd, 1977: 24). These researchers imply that intonational meanings are sometimes separate from syntax. Most recently, Goldsmith (1990) has introduced autosegmental and metrical phonology which focus on supersegmental aspects unlike classical generative phonology. Carr (1993) also includes autosegmental phonology as one of the current theories in his generative phonology book.

In spite of recent theoretical developments, the lack of wellformed pedagogical applications severely limit the benefit to second language learners. In the next section, a number of studies supporting the language students' need for help in learning intonation are discussed.

\section{SOURCES OF DIFFICULTIES IN ENGLISH PROSODY}

\section{Evidence that the Meanings of Supersegmentals are Not Universal}

As previously mentioned, without well-formed theory, effective textbooks for learning prosody cannot be easily developed. As a consequence, this aspect of communication tends to be neglected in terms of pedagogy. However, recent studies investigating intonation reveal that even advanced language learners have trouble with supersegmentals in both perception and production. 
With respect to perception, one interesting study was conducted by Luthy (1983) which examined how well nonnative English speakers understand English nonlexical intonation signals, [əhə], [?ou], and so on. Fourteen signals were recorded free of any verbal context, and played first to twenty-five native English speakers to decide whether they understood them without any visual or verbal clues. In the next phase, forty-two foreign students were tested in the same procedure to determine if there was a significant difference between them and native speakers. The findings indicate that the nonnative subjects seem to be lacking much of the understandings that native speakers automatically employ concerning nonlexical signals in communication.

Another study which provides evidence in support of the hypothesis that language learners have difficulty with comprehending the intonational patterns of a target language is CruzFerreira's (1987) research investigating nonnative comprehension of intonation in Portuguese and in English by speakers of English and Portuguese, respectively. A group of thirty native speakers of Portuguese and a group of thirty native speakers of English participated in this experiment and chose the correct answer from double binary alternatives. The results were statistically analyzed with the chi-square test for two independent subjects. Overall, it was clearly shown that the nonnative speakers had difficulty interpreting the intonation patterns of the second language. Furthermore, the researcher concluded that despite the fact that the interpretive strategy is dependent on the relationship between intonation patterns and lexico-grammatical features, it is possible to 
predict typical nonnative judgments on intonational meaning for each native language.

Not only the perception of intonation but also the production has been lately studied. Teaman (1992) investigated IL prosody. He focuses on the stress patterns of Japanese learners of English from native perceptual judgments. The aims of the study were the following: inquire how well the native English speakers can identify stress placement in the utterances, probe the notable characteristics of problems in Japanese learners' stress production, and examine what causes the problems based on the contrastive analysis. This experimental study included two steps: a data-collection phase and a judgments phase. In the data-collection phase, the task of generating natural speech with different types of normal and contrastive stress was given to four native Japanese speakers and four native English speakers. The judgment phase involved the data from the first step, extracting six native speakers' judgments of the English stress-accent. These judgments were used as a diagnostic tool to specify conspicuous characteristics of problems in nonnative stress productions.

The result illustrates that there was a much higher tendency for agreement on the native English speakers' tokens than the native Japanese tokens. Teaman therefore concludes that Japanese learners of English have the ability to produce stress forms that are categorically perceived by native listeners and moreover, developmental effects can be observed regarding the Japanese speakers in this study since the advanced learners' production was more satisfactory to the native judges. 
Another study examining Japanese subjects in IL prosody is Okumura's (1979) error analyses of the intonation patterns of their spontaneous utterances in English. She investigated thirty-four Japanese students, giving them a speaking test which included a set of questions and situations on a tape and a handout. While they were listening to the tape, the students responded to each question. Their utterances were recorded during the test. The result of the test was analyzed based on the Pearson Product-Moment Correlation. The findings indicate the general characteristics of intonational errors by the Japanese subjects as the following error types ordered from the most frequent error type to the least: prominence on additional words, errors in the end-utterance pattern, non prominence on required words, misplacement of sentence stress, and no variation in pitch. Using the contrastive analysis, the researcher drew the conclusion that the sources of the students' errors most likely stem from the interference of their native language.

Unlike the studies dealing with English described so far, Lepetit (1989) investigated the acquisition of French intonation by native speakers of Canadian English and Japanese. This study was composed of two experiments. The first experiment involved fortyfive Canadian Anglophone students who studied French. They were divided into three groups: first-year, second-year, and third-year French students. They were given a set of twenty five French sentences and asked to read them aloud. These utterances were recorded and analyzed with a pitch meter. In the second experiment, thirty Japanese students enrolled in the French Language Department in a Japanese university participated. A set of 
twenty two sentences were given to them. The same procedure was used as described above. What the researcher found was that crosslinguistic influence in intonation is essential in the learner's acquisition of the target system and also that the degree of complexity of the influence should not be underestimated. These two outcomes indicate that probing the correlation between L1 and L2 may be more effective than simply looking at direct L1 transfer in order to assess the L1 influence in the learner.

As can be seen from these studies, the first language has a great influence on acquisition of a second language. Specifically, Japanese learners of English have a tendency to apply Japanese phonology to English.

\section{Teaching English in Japan}

Although early awareness of English prosody should be an important component of English language teaching, current methods used to teach English in Japan are not appropriate in this regard. The first formal education in English starts in junior high school for most students and it is particularly important, given the significant loss of neuroplasticity with the onset of puberty, that they make a good beginning. However, there are some obstacles in reality. First, class size is so large, with forty students on average, that it is difficult for teachers to deal with individual students effectively. Second, classes emphasize memorization and learning English grammar, rather than using English for communication, so many students quickly lose interest. Moreover, due to the restrictions of the Ministry of Education's Course of Study, teachers are only allowed to choose 
certain textbooks regarding grammar. As a result, individual teachers are forced to perform with severe limitations. Third, in general, junior high school teachers are not as well qualified as senior high school teachers (see for example, Kitao et. al, 1985). For these reasons, the teaching methods are not designed to develop perceptual abilities in both pronunciation and communication.

Not only the methods used in Japan, but also the quality of English teachers should be considered. Japanese teachers of English are trained in universities of education or universities with teacher training courses (see Kitao et. al, 1985). Although teachers in both junior and senior high schools are required to have teaching certificates, the requirements do not stress teaching methods, practice teaching or performance in English. As the final step in becoming a teacher in a public school, a graduate who has a teaching certificate must pass a prefectural or municipal examination. This examination also focuses on theoretical knowledge rather than performance.

Therefore, it is not surprising that teachers who have successfully gone through this process still have difficulties in English oral skills. Despite the fact that team-teaching with native English speakers is becoming popular, many Japanese teachers of English are unable to communicate with English speakers. Even so, the Japanese teachers still have to take the initiative in the class (Homma, 1994). These Japanese teachers' English performance causes students' confusion and, even worse, retards their perceptual development (Zimmermann et al, 1984). Likewise, with regard to productive abilities, the teachers usually use audio-tapes including a native 
English speaker's pronunciation in order to cover their poor production. However, no particular techniques for teaching pronunciation are used, so students rarely learn correct pronunciation.

Despite these limitations, it is useful to examine Japanese learners' comprehension of English intonation, and to focus on the considerable improvements that can be made in teaching intonation. Specifically, it is useful to compare the Japanese intonation system which manipulates primarily duration and pitch, with the more elaborated English system of inter-related patterns of pitch, amplitude and duration.

\section{ANALYSIS OF ENGLISH AND JAPANESE INTONATION SYSTEMS}

One cannot deny the existence of L1 influence as discussed so far; therefore in order to devise the most effective teaching methods for each native language group, it is necessary to understand both L1 and L2 intonational systems.

\section{Japanese Intonation}

The two most important aspects of the Japanese intonational system are based on patterns of duration and fundamental frequency, and are characterized by syllable-timed rhythm and pitch. Bloch (1950) describes that "( $\mathrm{t}$ )he auditory impression of any phrase is of a rapid patterning succession of more-or less sharply defined fractions, all of about the same length" (1950: 90-1). For example, the phrase 'ka-o' (face) includes two fractions and the 
phrase 'ko-ko-ro' (heart) includes three fractions. The duration of phrases containing two fractions are approximately equal to 'ka-o' and the duration of phrases containing three fractions are equal to 'ko-ko-ro'. The duration can be carried by not only vowels but also by consonants. Vowel length is the basis for contrast between the phrase 'o-ku' (to place) to 'o-o-ku' (many, much). Consonant length is used such that 'ho-n' (book) is considered to be two fractions.

With respect to pitch, Bloch establishes four pitch phonemes of Japanese as follows: /1/ highest pitch, /2/ higher mid pitch, /3/ lower mid pitch, and /4/ lowest pitch (1950: 95). Bloch further describes that "each of the four pitch phonemes includes as members (allophones) all the sequences of vowels or consonants or both--from one to a dozen or more--that are heard as having a particular pitch" (1950: 95). The pitch phonemes of the phrase 'hi-ku-i' (short), for instance, are described as [hi] to $/ 4 /$, [ku] to $/ 2 /$, [i] to $/ 4 /$. The phrase 'ka-mi', for instance, has two meanings depending on pitch: [kàmi] (God) and [kamì] (paper). These syllable-timed rhythm and pitch play essential roles for the intonational system in Japanese.

\section{English Intonation}

In contrast to Japanese intonation, which seems to rely primarily on duration and pitch, English intonation involves a complex inter-relationship among duration, pitch, and loudness, all of which interact (see for example, Beckman and Pierrehumbert, 1986). In phrase and sentence contexts, whereas English involves a complex phonetic realization of accent, Japanese relies primarily on pitch. As Lea's (1977) study indicates, native English speakers manipulate 
pitch, loudness, and length in complex ways to highlight stressed words in context. Consequently, this complexity makes it extremely difficult for Japanese learners of English to learn English pitch accent since the intonational phrase is made by applying a pitch contour to a metrically marked phrase, unlike Japanese.

This is a crucial aspect because the prominence of phrase/sentence stress affects word stress and changes its intonation pattern. This study therefore focuses on the sentence stress level. It is clear that these differences possess potential sources of difficulties in learning English prosody.

Similarities Between English and Japanese Intonational Systems

While Beckman (1986) distinguishes English as a prototypical stress-accent language and Japanese as a prototypical non-stressaccent language, quite a few similarities between the two prosody systems should be noted. According to Beckman and Pierrehumbert (1986), two of the substantial similarities are that both have tonal phenomena and pitch accents and that accentual phrase tones are restricted to being one or two-tone units. In Japanese the place of the accent is lexically contrastive, such as in $a^{\prime} m e$ 'rain' vs. $a m e^{\prime}$ 'candy'. Likewise, in English the contrast, as in 'próject' vs. 'projéct', is specified in lexicon. Although the form differs for both languages, accent functions for distinguishing a lexical category, which means that accent is unpredictable, are similar.

Another similarity is that the two-tone accents cause a phenomenon of tonal implementation called 'downstep' or 'catathesis' in both languages. Catathesis, which "compresses and lowers the 
pitch range in certain circumstances" (Beckman and Pierrehumbert, 1986:273), explains 'mid' tones in contours. The most accentually prominent point, a stressed point, can be used to connect one of a selected number of intonation contours.

Furthermore, both English and Japanese share more intonational features in detailed levels. Beckman and Pierrehumbert's (1986) offer several examples. For instance, in both languages catathesis appears to occur only within some intermediate level of phrasing. This occurrence is closely linked to "organizational effects" including the facts that the intermediate phrase is the domain of the catathesis and that an intermediate phrase break can occur. In addition, larger prosodic units are marked by boundary tones which play a role of filling the space after the last pitch in a phrase. These tones are not phonologically related to any particular tone unit in either language. The boundary tone at some level can be $\mathrm{H}$ (high), and the choice of a $\mathrm{H}$ tone at this level has resembling pragmatic effects in both English and Japanese. Thus, the two language have a general similarity in terms of the intonational systems in that both organize the tone features into a hierarchy of prosodic structures, "from the grouping of tone into pitch accents at a local level to the choice of phrase-terminal tones and the manipulation of pitch range over larger domains" (Beckman and Pierrehumbert, 1986:305).

Similarities are observed even in a speaker's attitudinal meaning in both Japanese and English. Abe (1955) describes similar intonational expressions in the two languages. First, the falling intonation is employed at the end of an utterance in the case that the 
speaker makes a statement in a matter-of-fact way. Second, a rising or a raised pitch is used if "the speaker is appealing (strongly) to the hearer or calling for the latter's 'participation' in or sympathy with his view or statement" (Abe, 1955:392). Third, the question particle $k a$ is usually employed for interrogation and special questions with a rising or falling intonation, but once in a while used differently in Japanese as follows:

('I can't tell a flatfish from a sole. Tell me ...')

Korega hirame desuka? (rise or sustained pitch)/ Is this a flatfish?

('Now I see the difference between a flatfish and a sole')

Korega hirame desuka! (fall)/ This is a flatfish, isn't it?

Such a phenomena is also observed in English as below:

Is that 'so? (ordinary question)

Is 'that `so? (astonishment but willingness to agree) adopted from Abe

$(1955: 393)$

Fifth, if a question is an 'information-seeking' type, the speaker gradually lowers the intonation at the end of utterance in the two languages. Furthermore, if the speaker adds a slight rise, instead of a fall, to the utterance, s/he implies curiosity or sincerity. Sixth, if the interrogative word appears with a high pitch and stress and the sentence-final is pronounced with the falling intonation, the utterance connotes accusation, Finally, if a 'convex intonation' is added to the utterance like Nanio yattêruno, it would then become a sarcastic comment as can be seen in 'what are you do'ing? in English (Abe, 1955:398). 
Differences Between English and Japanese Intonational Systems

There are also differences between these two systems. First of all, Japanese has lexically unaccented words whereas English does not (see for example, Beckman, 1986). Japanese therefore can have well-formed words without any underlying pitch accents, which would not happen in the English intonation system.

Second, Japanese uses only pitch to indicate lexical stress, while English involves pitch, loudness and length (see for example, Beckman and Pierrehumbert, 1986). In Japanese, pitch accents have a fixed tonal shape, and their possible loci in lexical items are not differentiated by having longer duration or a different set of vowel types as are English accent loci. Precisely speaking, as Bloch (1950) points out, variations in loudness can be observed in Japanese, though, such utterances are predictable by pitch phonemes. This difference seems to be seriously problematic for Japanese learners of English since English relates any one of a number of intonational contours to the same metrically marked string.

\section{PEDAGOGICAL VIEWS FOR ACQUISITION OF INTONATION}

\section{Teaching Techniques for Supersegmentals}

In considering the problems for Japanese learners of English, the following classroom activities seem to be useful: music, poetry, jazz chants, dialogs, and role-plays. One of the popular techniques is using music. Since most Japanese students enjoy listening to music, it can be a good introduction for listening practice. A teacher chooses music that will help students focus on particular aspects. The 
students listen to the song a couple of times and do fill-in-the-blanks to the song. It would be efficient to combine pronunciation practice with some other skills such as listening and grammar. At the end of class, the teacher has students sing the song together.

Using poetry is a good exercise for English pitch stress. Since poetry provides some of the clearest examples of the rhythm of English, it is of particular help to Japanese students because Japanese is a syllable-timed language. One of the techniques is that students listen to the beat of the strongly stressed syllables in lines and tap their finger on their desk at each strong syllable (see Sheeler and Markley, 1991).

Jazz chants can be used as practice for a variety of aspects in English pronunciation. A teacher decides on his/her focus, such as particular intonation, rhythm, stress and so on. At the next step, s/he brainstorms a set of words and sentences followed by question response and response patterns. Finally, the teacher puts them together using repetition (see Graham, 1992,1978). In classroom, students chorus the chant, responding to the teacher. This repetition, as well as the exaggeration of jazz chants, can help Japanese students to learn what are the characteristics of English supersegmentals.

Dialogs and role-plays can be also effective practice for stress and intonation, if they are specifically designed by the instructor for that purpose. Contrasting and ambiguous statements, depending on intonation, should be emphasized because Japanese does not use stress and intonation in the same way as English. The instructor should help students to understand how intonation influences the meaning of utterance (see for example, Kenworthy,1987). 
Learner's Self-involvement and Teacher Involvement

Not only teaching techniques, but also teacher involvement plays an important role for overall pronunciation instructions. Many researchers such as Borden and Milsark (1983), O'Malley and Chamot (1989), Oxford (1990), and Morley (1991) emphasize the importance of a learner's awareness and attitudes in the learning process. According to Morley (1991), the most effective way to become intelligible, communicative, confident speakers of English seems to be getting consciously involved in the speech modification process.

In addition, Morley (1991) suggests that a teacher should get involved in helping the learners. Especially in pronunciation work of second language instruction, the teacher should be a facilitator in a special learner-centered way. From her point of view, the teacher should be much more like a "coach" to assist the learners. The coach has to play the very important role of monitoring and guiding modifications of spoken English at two levels: speech production and speech performance. Although articulatory phonetics are critical, the larger communicative picture of getting the message across should be also considered.

Despite the fact that adult learners of English need a long time to master new phonological systems, with effort they can overcome many of the difficulties. As a result, research into devising new methods of training should be done. Such research might be able to bring a dramatic change to the prevailing pronunciation teaching.

Integrated Approaches to Teaching Oral Communication Skills

Traditional pronunciation teaching focuses on sound 
discrimination and recognition exercises. This practice still remains in modern classrooms. However, there has been a trend toward more integrated approaches to teaching oral communication skills as a whole. Gilbert (1987) claims that pronunciation practice should be closely linked to listening activities. Murphy (1991) also states that microlevel phonological information brings needed keys that help target language listeners to comprehend what they hear.

Furthermore, practice with identification and use of these keys is one of the ways to establish a stable foundation for oral production activities. This is because microlistening involves the aural discrimination of sound features within streams of speech.

Bohlden and Macias (1992) also say that a listening skill can enhance overall skills in learning English. They address stages toward which nonnative speakers of English should move. First, they listen to the phonemes and observe the instructor producing the sounds in isolation. In the next step, they reflect the sounds simultaneously to the speaker without substitution or distortion of the phonemes presented. Third, they discriminate the appropriate sound within the word's initial, medial, and final positions. Once the learner is able to correctly pronounce the problematic sounds he/she can go to the next step. In the final stage, accurate pronunciation and correct use of intonation are emphasized.

This new trend of pronunciation teaching can be observed in recent text books for pronunciation. A textbook compiled by Hogan and Grogan (1992) which contains listening and production exercises as well as a clear-cut explanation of every aspect of pronunciation, especially supersegmentals, are well done. Sheeler and Markley 
(1991) equally did a very good job on their pronunciation course book focusing on basic rhythm, stress, and intonation in English.

These integrated approaches are very beneficial. However, a teacher should keep in mind, depending on students' needs, what the objectives and goals are. In light of the requirement of oral skills in English by Japanese Ministry of Education, the present method should be reconsidered and gradually changed in the integrated approach. This is necessary to reach the goals, namely, to be able to communicate with native English speakers, and to express feelings or opinions in English and to discuss various topics (Homma, 1994). Regardless of segmentals or supersegmentals, these approaches provide diverse opportunities for the development of oral proficiency for second language learners of English.

\section{SUMMARY}

Despite the difficulty of acquiring intonation for second language learners, very few of them experience being exposed to intonation teaching methods in class. This fact is due to the absence of appropriate pedagogical applications of theories. Fortunately, however, intonation has caught the attention of many applied linguistic researchers in recent years.

Japanese speakers of English, nevertheless, are no exception to having the difficulty. Some researchers claim that L1 has great influence on learning intonation in L2. In this sense, it is essential to investigate both English and Japanese and figure out whether L1 truly affects learners' acquiring intonation. Previous studies that 
examined Japanese speakers were limited only to their production. The present study, however, focuses on Japanese speakers' comprehension of English intonation in order to identify the problems they have on acquiring intonation. The results will help teachers to devise specific pedagogical methods which would work for Japanese students most effectively. 
CHAPTER III

\section{METHOD AND PROCEDURE}

In this chapter, the procedure and method of the present study will be explained. Both Japanese and American students took a comprehension test of intonation in English and their results were statistically analyzed.

\section{METHOD}

The research presented was an experimental design employing a comprehension test for English intonation developed by CruzFerreira (1989). T-tests and chi-square tests were used to evaluate the collected data. Based on her suggestions for test procedure, the following experiment was conducted.

A set of 40 sentences (Appendix A) was presented by audio tape to examine Japanese speakers' perception of English intonation. The subjects listened to each utterance and chose one of three interpertations. The collected data were analyzed primarily from two perspectives: types of errors and ESL levels of the subject. With respect to types of errors, the meaning of each sentence was categorized into three groups established by Cruz-Ferreira: 
(i) paraphrase, in which the meaning conveyed by intonation in each sentence is reproduced by lexical or syntactical means. Example:

(2) I know Bill's son John/ and 'Harry (Bill's son = John)

(22) I know Bill's son/ John/ and 'Harry (Bill's son $\neq$ John)

(ii) categorization, referring to the sentence type/illocutionary function of each sentence. Example:

(1) they've bought a new car (statement)

(21) they've bought a'new car (question)

(iii) attitudinal judgments, giving the underlying attitude of the speaker by means of descriptive labels. Example:

(11) what are you doing here (in a rude way)

(31) what are you'doing here (in a neutral way)

Errors on these pairs of contrastive intonation patterns were also investigated to judge how well subjects could truly comprehend the difference between the two variations. Furthermore, general versus local intonation was taken into consideration in order to see whether there is any relationship between the patterns of their errors and this view. In any case, differences in each level were investigated. 


\section{SUBJECTS}

The 74 Japanese subjects were ESL, undergraduate, postbaccalaureate, and graduate students in the Portland area who volunteered to participate in this study. Of them, 30 (two male and 28 female) were ESL students at an intermediate or advanced level of the ESL program, ranging from 18 to 49 in age. The rest of them (17 male and 27 female) were undergraduate, postbaccalaureate, or graduate students who have a high ESL level and at least one year of experience in English speaking countries or at least a 550 TOEFL score. Their ages ranged from 20 to 47 . The 31 American subjects (20 male and 11 female) were native speakers of American English enrolled at Portland State University, whose ages ranged from 18 to 46.

The ESL subjects were enrolled in three different ESL programs. Fourteen were in the ESL program at Portland State University designed for Otemae College students in Japan, seven were in the level four grammar class and three were in the level three writing class at Portland State University, and six were in the ESL program in another college. Their length of stay in the USA ranged from one month to three years. Of the 30 ESL subjects, 22 had some experience of staying in an English-speaking country, such as the USA and Canada with the length of stay ranging from three days to two years. Their purpose of visiting such English-speaking countries was either to study English or travel. In addition, half of 
them had TOEFL scores from 400 to 523, and the other half did not report their TOEFL scores.

The non-ESL subjects were categorized into the following: 23 undergraduate, 12 graduate, eight postbaccalaureate students, and one other. The majority of the students were enrolled at Portland State University. Their length of residence in the USA ranged from one month to nine years. Their visit to English-speaking countries included not only the USA and Canada, but also Great Britain and Australia. The shortest length of stay in such countries was four days and the longest, five years and two weeks. As far as their experience of living in English-speaking countries, only two of the non-ESL subjects' (\#37, \#53) length of stay did not reach a year. However, these two subjects are appropriate for this study since they had TOEFL scores equal to or greater than 550. Of the non-ESL subjects, 38 provided their TOEFL scores, which ranged from 460 to 620. One has to bear in mind that these TOEFL scores do not necessarily reflect their actual English level at the time the test was conducted since it, is not clear when they received the score. Judging from these two given conditions, the length of stay in English speaking countries, TOEFL score, as discussed before, it was assumed that the non-ESL group had a higher level of understanding of English than the ESL group. Accordingly, the former are defined to be advanced level subjects and the latter, as lower level.

The American subjects were grouped into 21 undergraduate, four graduate, four postbaccalaureate students, and two others. All 
of the American subjects spent a majority of time in the USA, speaking American English.

\section{MATERIALS}

Materials used in this study are as below:

1. Test questions

2. Test audio tape (questions)

3. Answer sheets

4. Multiple choice Scantron form

5. Survey sheets.

The test sentences were adopted chiefly from the intonational comprehension test for nonnative speakers of English as presented by Cruz-Ferreira (1989). However, due to the limited number of the test sentences, supplementary test sentences were added to the test. Consequently, 48 test sentences (24 pairs of contrastive variations of intonation) were originally used, but only 40 sentences were selected after the pilot study, as discussed in the following section.

The test sentences were tape recorded by a phonetically trained native speaker who spoke each sentence once. This tape was produced using an Andro Technica ATM31a condenser microphone, a Tascam 202MKII recorder, and a Philips FA950 Amplifier. Each utterance was digitized and duplicated three times by computer, instead of repeated readings, so as to avoid variation in the speaker's utterance. A five-second interval between each reading and a threesecond interval between a question number and a test sentence were 
provided. Consequently, subjects were to have eighteen seconds to answer each question. The tape was played through headphones in a language laboratory.

The interpretations $a ., b$. , and $c$. and each variation of the pairs were randomized and translated into Japanese. The reason for this was to minimize the impact of the variation of English reading comprehension of L2 on the data. Cruz-Ferreira (1989) notes that ambiguous interpretations of learners might possibly produce misleading final results, although translation of each interpretation may cause other problems to affect the outcomes. For example, the translation could be ambiguous in Japanese, or it could become wordy to describe the precise English expression. Yet this seemed to be the best way to collect the most accurate data.

In addition to the main test sentences, four pretest sentences were provided. The pretest helped the subjects to get a clear picture of the main test and understand exactly what they were supposed to do.

The Japanese subjects were given multiple choice answer sheets translated into Japanese (see Appendix B) and a scantron form for marking down each response. Additionally, a survey sheet (Appendix C) was given to each subject to collect information concerning their age, gender, TOEFL score (if applicable), length of time that $\mathrm{s} / \mathrm{he}$ had been in the US, and experience of learning English. 


\section{PILOT STUDY}

In order to find out if there were any problems with the test materials, a pilot study was conducted. Five native speakers of American English, two Japanese ESL students, and three Japanese non-ESL advanced students volunteered to participate in this pilot study.

Before the testing of Japanese subjects, American subjects were examined to see whether the recorded test sentences and their written interpretation would be appropriate. The results showed that all the American subjects interpreted correctly for about half of the test sentences. On the other hand, they did not all agree with the correct answers on the rest of the questions. What is more, the majority of them misinterpreted the same sentences. Considering the personal advice by Cruz-Ferreira that $100 \%$ native agreement in the tests seems to be rare, but the overwhelming statistical significance exists between native and nonnative speakers, the researcher decided to omit only sentences where the majority of the American subjects disagreed with the correct answers. To be consistent, the associated sentences were also eliminated. As a result, the number of the questions was reduced to forty. One interpretation written in English was also changed, according to the subjects' opinions. That is, one of the interpretations for question 10 "I went out, but not because I wanted to see you" was changed to "I stayed home, but not because I wanted to see you". 
Japanese subjects took the same test as the American subjects. The only difference was that the question and answer packet was translated into Japanese. Though not conclusive, the results from the pilot study indicate little if any significant difference between the lower level and advanced level Japanese students. Finally, the critical comments by the American pilot test subjects as above led to the omission or the modification of some of the pilot test question. These changes were reflected in the questions presented to both the American and Japanese subjects in the main study.

\section{PROCEDURES}

\section{Data Collection}

Due to the large number of subjects in this study, test schedules were divided into numerous sessions, depending on each subject's availability. In most of the sessions, a group of fewer than ten subjects took the test at the same time. On two occasions more than 15 Japanese subjects were tested.

In addition, American and Japanese subjects were separately examined in order to avoid any misunderstanding that using the second language might cause, especially with the Japanese native speakers. Accordingly, the researcher explained a test procedure to Japanese subjects in Japanese, and to American subjects in English.

\section{Test Explanation and Instruction}

Before the subjects actually listened to a tape, they were given 
detailed instructions. The test was explained to the Japanese subjects in Japanese. A cover letter, which provided a general description of the study and explained their rights as human subjects, was given to all test subjects. All the subjects were informed that the purpose of the test was to examine how well they comprehend the intonation of English. They were then given a survey sheet and asked to fill it out.

After the subjects filled out the form, the researcher briefly explained to them the test procedure. They were informed that all they had to do was listen to each intonation, choose an interpertation, and mark it down in their Scantron from. It was also explained that the 40 questions were composed of 20 pairs of contrastive variation and after the first 20 questions, 20 questions of the other variation would come in the same order. The set of answers for the last twenty questions, therefore, was the same as the first. For the Japanese subjects, a Japanese example was presented to demonstrate how different intonation patterns convey different meanings.

An answer sheet and a Scantron form were then distributed to each subject. All the subjects were asked to write down only their subject number on their Scantron form. For practice, a pretest was given before the main test. When the pretest was over, the researcher stopped the tape and asked the test subjects if they had any questions regarding the test. Explanations that might provide some kind of hint, however, were carefully avoided. The main test was then administered without interruption. The subjects were, 
therefore, not allowed to ask any questions during the main test. It took approximately 20 minutes to complete the test.

\section{DATA ANALYSIS}

\section{Questions to be Analyzed}

The performance of the American subjects played a crucial role as a control group in the assessment of the performance of the Japanese subjects in this analysis. Table I shows the percentages of correct answers for each question by the American subjects. On some question pairs the American students performed poorly or inconsistently. In order to identify question pairs to be considered for certain statistical analyses, $70 \%$ correct and $80 \%$ correct thresholds were established. In Table I the cross-shaded cells indicate question pairs for which the American subjects scored $80 \%$ or greater on each question. The stripe and cross-shaded cells represent pairs for which their responses were $70 \%$ or greater for each question. These standards established a basis for determining which question pairs are sufficiently valid for analysis.

\section{Analysis by Different ESL Levels}

In addition to the American group, two groups of Japanese subjects, lower and advanced levels, were analyzed separately, according to their ESL levels. As described earlier, the tested Japanese subjects were either ESL students or regular students who enrolled in a junior college, a university, or a graduate school with 
TABLE I

PERCENTAGES OF CORRECT ANSWERS FOR EACH QUESTION BY AMERICAN SUBJECTS

\begin{tabular}{|c|c|c|c|c|c|}
\hline Question & $\begin{array}{l}\text { Percent } \\
\text { Correct }\end{array}$ & Question & $\begin{array}{l}\text { Percent } \\
\text { Correct }\end{array}$ & $\begin{array}{c}\text { Both } \\
\text { Questions }\end{array}$ & $\begin{array}{c}\text { Question } \\
\text { Type }\end{array}$ \\
\hline 1 & $96.8 \%$ & 21 & $83.9 \%$ & $80.6 \%$ & $\mathrm{C}$ \\
\hline 2 & $80.6 \%$ & 22 & $64.5 \%$ & $54.8 \%$ & $P$ \\
\hline 3 & $87.1 \%$ & 23 & $90.3 \%$ & $77.4 \%$ & $P$ \\
\hline 4 & $61.3 \%$ & 24 & $93.5 \%$ & $61.3 \%$ & $\mathrm{P}$ \\
\hline 5 & $96.8 \%$ & 25 & $93.5 \%$ & $90.3 \%$ & $P$ \\
\hline 6 & $96.8 \%$ & 26 & $96.8 \%$ & $93.5 \%$ & $\mathrm{C}$ \\
\hline 7 & $87.1 \%$ & 27 & $100.0 \%$ & $871 \%$ & $\mathrm{P}$ \\
\hline 8 & $96.8 \%$ & 28 & $83.9 \%$ & $83.9 \%$ & $P$ \\
\hline 9 & $96.8 \%$ & 29 & $96.8 \%$ & $93.5 \%$ & $P$ \\
\hline 10 & $61.3 \%$ & 30 & $100.0 \%$ & $61.3 \%$ & $P$ \\
\hline 11 & $100.0 \%$ & 31 & $93.5 \%$ & $93.5 \%$ & $A$ \\
\hline 12 & $74.2 \%$ & 32 & $90.3 \%$ & $71.0 \%$ & $\mathrm{P}$ \\
\hline 13 & $71.0 \%$ & 33 & $90.3 \%$ & $67.7 \%$ & $P$ \\
\hline 14 & $61.3 \%$ & 34 & $100.0 \%$ & $61.3 \%$ & $P$ \\
\hline 15 & $54.8 \%$ & 35 & $93.5 \%$ & $51.6 \%$ & $\mathrm{C}$ \\
\hline 16 & $77.4 \%$ & 36 & $87.1 \%$ & $71.0 \%$ & $\mathrm{P}$ \\
\hline 17 & $74.2 \%$ & 37 & $100.0 \%$ & $74.2 \%$ & $P$ \\
\hline 18 & $58.1 \%$ & 38 & $51.6 \%$ & $38.7 \%$ & $P$ \\
\hline 19 & $93.5 \%$ & 39 & $100.0 \%$ & $93.5 \%$ & $A$ \\
\hline 20 & $96.8 \%$ & 40 & $93.5 \%$ & $90.3 \%$ & $P$ \\
\hline
\end{tabular}

NOTE: Cross-shaded areas indicate $80 \%$ or more of correct answers and the cross and stripe-shaded areas show $70 \%$ or more of correct answers. As to the question type, C stands for categorization, $\mathrm{P}$, paraphrase, and $\mathrm{A}$, attitudinal judgments. 
the following conditions: either a length of stay in an English speaking country of at least a year, or a TOEFL score of 550 or greater (see Appendix D). These factors separated the Japanese subjects into two groups according to ESL levels, for the purpose of determining whether or not there was any difference in their abilities to understand English intonation.

However, when probing other potential variables that might influence to their intonation test scores, these two groups were consolidated. In the collected personal information (see Appendix C), age, TOEFL scores, the length of stay in English speaking countries, and the length of studying English were analyzed using correlation coefficients and multiple regression tests.

\section{Types of Intonation}

As can be seen from Table I, there are three types of intonation to be analyzed: paraphrase, categorization, and attitudinal judgments. 15 pairs (30 sentences) belong to paraphrase, three pairs (six sentences), categorization, and two pairs (four sentences), attitudinal judgments. nine paraphrase pairs (18 sentences), two categorization pairs (four sentences), and two attitudinal judgment pairs (four sentences) met or exceeded the $70 \%$ validity threshold. At the $80 \%$ validity threshold, only five paraphrase pairs (10 sentences) qualified. The rest of the intonation types remained unchanged. In order to determine whether Japanese subjects' errors are systematic or not, these types of intonation errors were analyzed separately. 
Evaluating Contrastive Variations of Intonation

If the Japanese subjects indeed understand intonation, they should answer a pair of both contrastive variations correctly. Due to the shortcoming of multiple choice tests, the so-called 'intelligent guess' might often be observed. Although completely eliminating this problem was impossible, its magnitude was evaluated by scoring and examining their pair variations.

Two kinds of analyses were conducted. The first analysis is to find out whether subjects who answered one question correctly also correctly answered the other question of the pair. A chi-square test was used to determine if the Japanese subjects' performance in answering contrastive pairs were consistent.

Second, three interpretations for each question were classified into three groups so as to find how different or close the American and two Japanese groups' error patterns were. The groups were correct, appropriately wrong, and absolutely wrong answers. Incorrect answers, in other words, were divided into two categories as the above. Appropriately incorrect were those answers which were the correct response for the contrastive variation. In this case, the subjects might misinterpret intonation itself for the other variation or they might guess and choose it from its lexical item or syntactic structure.

The absolutely wrong answers, on the other hand, imply a complete misunderstanding of the variations of an intonation pair. Such answers were either grammatically incorrect or completely out of context. However, two native speakers pointed out that three 
question pairs (11-31,15-35, and 19-39) were not clearly out of context. Questions 11 and 31, for example, the test utterance "What are you doing here?" can be interpreted to mean that the speaker is asking it in a polite way as well as a neutral or rude way, depending on the hearers' standard of politeness. For questions 15 and 35, the utterance "Would you like tea or coffee?" is possible to be understood as the speaker wants to offer coffee instead of tea, for instance, if he/she is holding a coffee pot, or says the word 'coffee' extremely loud. Questions 19 and 39 appeared to be most troublesome because the utterance "John passed his exams" with a surprised intonation like question 19 could be misinterpreted for a question sentence. Although these three should not be considered absolutely wrong answers, the number of the American subjects who chose the absolutely wrong answer for these questions was very small with either one or two; thus, they were not eliminated from the analysis. Proportional scores, a t-test, and a chi-square test were employed in this analysis.

\section{SUMMARY}

The results of a comprehension test for English intonation taken by 74 Japanese subjects studying in the United States and 31 American subjects enrolled in Portland State University were examined in this study. The Japanese subjects were divided into two groups, advanced and lower levels, according to their school status, length of stay in English speaking countries, and TOEFL score. As a 
result, these three groups were compared and analyzed in order to find how well Japanese learners of English understand intonation in English.

The test which was modified from the original version developed by Cruz-Ferreira (1989) included 40 questions of 20 pairs of intonational variations. Based on her suggestion of the test procedure, the experiment was conducted and all the questions were classified into three types of intonation to see if there was any evidence of error patterns.

After having collected all the data, the scores of American subjects indicated that it was necessary to eliminate some of the test questions in some analysis. Hence, when necessary, only question pairs which met the $70 \%$ or $80 \%$ validity thresholds were used to analyze the performance of the Japanese subjects.

Furthermore, for each question pair, contrastive variations of intonation were closely examined. First, subjects who got one question right were investigated to see how many of them answered the other variation correctly for each question pair. Second, incorrect answers were classified into two groups: appropriately wrong and absolutely wrong answers. These subgroups were analyzed in order to determine the specific type of intonation difficulty experienced by Japanese learners of English. 


\section{CHAPTER IV}

\section{RESULTS}

The findings of this study, as to the Japanese subjects' understanding of English intonation, are presented in this chapter. Their performance is evaluated mainly from the aspects of different ESL levels, types of intonation, contrastive variations of intonation, and error patterns. All statistical assessments were at an $\alpha=0.05$ significance level assuming unequal variances.

\section{PROCEDURE}

One hundred and five answer sheets were divided into these subject classifications: American students (31), advanced level Japanese students (44), and lower level Japanese students (30). The overall performances of each of these groups were evaluated and compared for the entire question set and for each of the twoquestion-pair subsets described in Chapter III (the $70 \%$ or $80 \%$ validity subsets). In addition to evaluating each group's overall performance, their performances were examined from the perspective of intonation type (paraphrase, categorization, and attitudinal judgments). Finally, the performances of each group with respect to contrastive sentence pairs were evaluated. Specifically, 
assessments were made of correct, appropriately wrong, or absolutely wrong responses to the second question of a contrastive pair, in association with a correct response to the first question of the pair.

\section{RESULTS}

\section{Overall Performance of the Intonation Test by Japanese Subjects}

The outcomes indicate that Japanese subjects have more difficulty understanding English intonation than American subjects. Figure 1 shows the distributions of each of the three groups' (Americans, advanced level Japanese, and lower level Japanese students) percentage scores of correct answers for all 40 questions. Additionally, corresponding descriptive statistics are summarized in Table II. As can be seen from the score distributions of correct answers, both of the Japanese groups demonstrated much lower scores than the American group. Out of 40 questions, the mean score of the American subjects was 34.3 (85.6\%), the advanced level Japanese students was $25.7(64.1 \%)$, and the lower level Japanese students was $25.2(63.0 \%)$. The standard deviations of these groups were $4.2,3.5$, and 3.9 , respectively.

This information indicates that, while the differences between

the American group and each Japanese group was sizable, there appears to be no salient difference between the two Japanese groups. The significance of these differences were evaluated using t-tests. At 

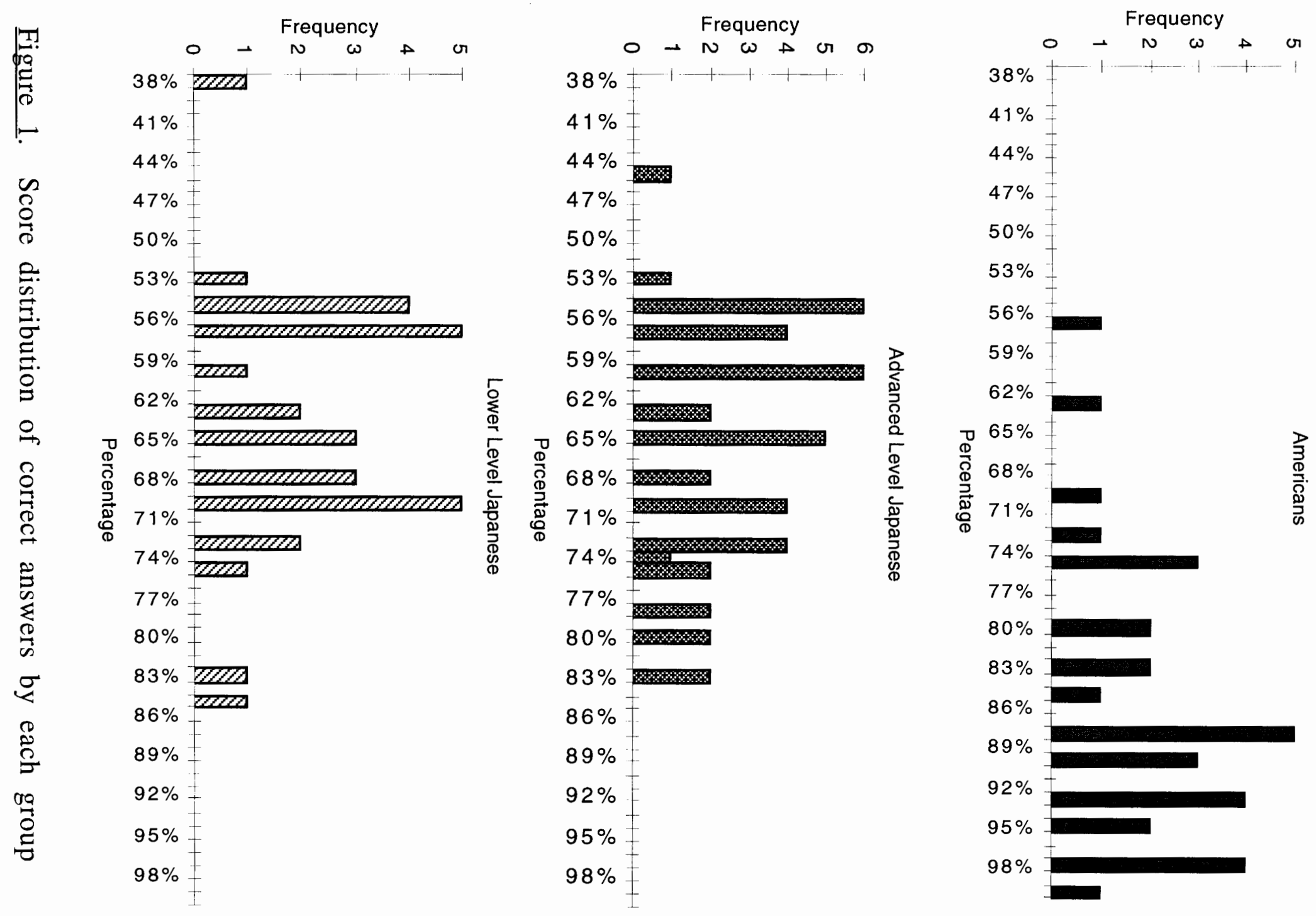
TABLE II

DESCRIPTIVE STATISTICAL SUMMARY

\begin{tabular}{|l|c|c|c|}
\hline \multicolumn{1}{|c|}{ Subject Group } & Mean Score & $\begin{array}{c}\text { Relative } \\
\text { Score }\end{array}$ & $\begin{array}{c}\text { Standard } \\
\text { Deviation }\end{array}$ \\
\hline Total Question Set & 34.3 & $85.6 \%$ & 4.2 \\
American & 25.7 & $64.1 \%$ & 3.5 \\
Advanced Level & 25.2 & $63.0 \%$ & 3.9 \\
Lower Level & & & \\
70\% Validity Threshold Subset & 23.8 & $91.7 \%$ & 2.4 \\
American & 18.6 & $71.7 \%$ & 2.7 \\
Advanced Level & 18.0 & $69.4 \%$ & 3.1 \\
Lower Level & 17.0 & $94.6 \%$ & 1.2 \\
$80 \%$ Validity Threshold Subset & 14.1 & $78.3 \%$ & 1.9 \\
American & 13.7 & $76.3 \%$ & 2.2 \\
Advanced Level & & \\
Lower Level & & \\
\hline
\end{tabular}

this level the differences between the American group and each of the two Japanese groups proved to be significant. In fact, the risk of a Type 1 error was less than $0.1 \%(\mathrm{p}=0.001)$. With regard to the two Japanese groups, however, the $\mathrm{t}$ statistic $(\mathrm{t}=0.609)$ did not support rejecting the null hypothesis that the means of these two groups were equal.

\section{Analysis of $70 \%$ Validity Threshold Subset}

As mentioned in Chapter III, the performance of the American group on certain test sentences brought into question the validity of these sentences. As such, two subsets of the entire set of test sentences were defined, based on the performance of the American (control) group, to establish specific levels of validity (the $70 \%$ 
correct threshold and the $80 \%$ correct threshold). Figure 2 depicts the score distributions for the $70 \%$ subset. Comparing the distributions in Figure 2 which the corresponding distributions in Figure 1 reveals that the performances of all three groups have increased markedly and are more consistent. These observations are evidenced by means of $23.8(91.7 \%), 18.6(71.7 \%)$ and $18.0(69.4 \%)$ for the American, advanced level, and lower level groups, respectively, and by corresponding standard deviations of 2.4, 2.7, and 3.1 .

As with the entire question set, t-tests were employed to assess whether or not differences between these group means were statistically significant for the $70 \%$ threshold subset. These t-test results were in agreement with those previously presented. Again, t statistics supported (at a significance level of less than 0.001) rejecting the hypotheses that the mean scores of either of the Japanese groups equaled that of the American group. Also, the $t$ statistic, with a significance level of 0.394 , did not support rejecting the hypothesis that the mean scores of the two Japanese groups were equal.

\section{Analysis of $80 \%$ Validity Threshold Subset}

To address possible concerns that a $70 \%$ validity threshold may not be considered sufficiently rigorous, the data associated with the question subset meeting $80 \%$ validity threshold were also examined. With regard to this validity subset, 15 out of 30 American students scored $100 \%$, and no American subject scored less than $72 \%$. 

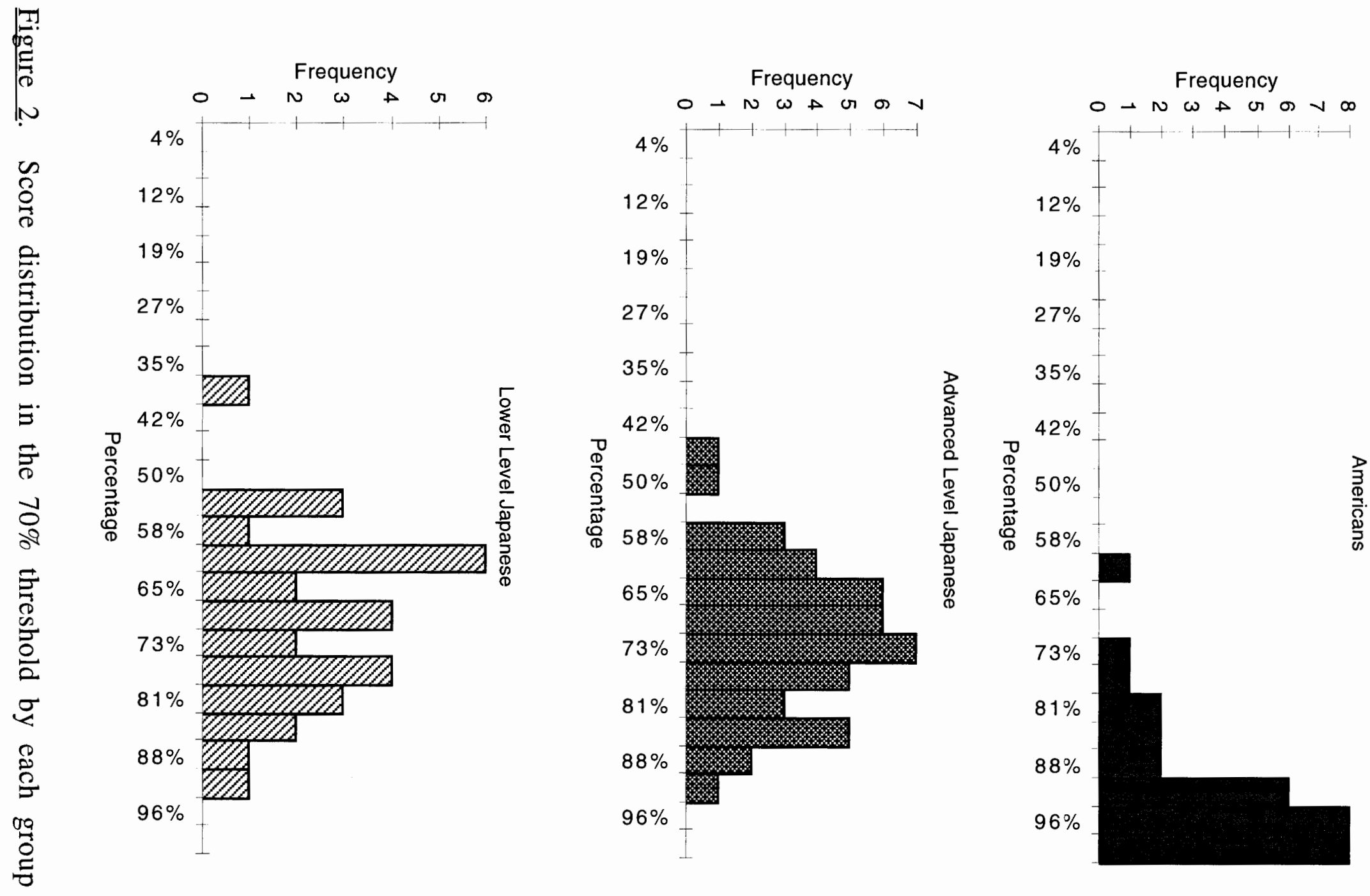
The results, shown in Figure 3, demonstrates a similar tendency to that observed in the analysis of the $70 \%$ threshold subset. The distributions of the three groups have continued to shift toward a higher percentage, and the variation in scores has continued to narrow. Specifically, the means (and standard deviations) for the Americans, advanced level and lower level groups were 17.0 (1.2) 14.1 (1.9), and 13.7 (2.2), respectively.

Again t-tests were used to determine whether the differences in group means were significant. As before, the performance of the American group was significantly greater than either of the Japanese groups, and the data did not demonstrate statistically significant differences in the performances between the two Japanese groups.

In summary, these three analyses comparing the overall performances of the American subjects, the advanced level Japanese students, and the lower level Japanese students lead to a conclusion that Japanese students do have significantly more difficulty in understanding English intonation. According to ESL levels of Japanese subjects, on the other hand, no significant difference was observed. In order to determine if this tendency applies to specific types of intonation, all 40 questions were classified into three groups of intonation patterns and are analyzed in the next section.

\section{Types of Intonation}

Overall Performance of Paraphrase. As described in Chapter III, there are 15 paraphrase question pairs (30 sentences) out of all 40 questions (see Table I). Each group's score distribution for this 

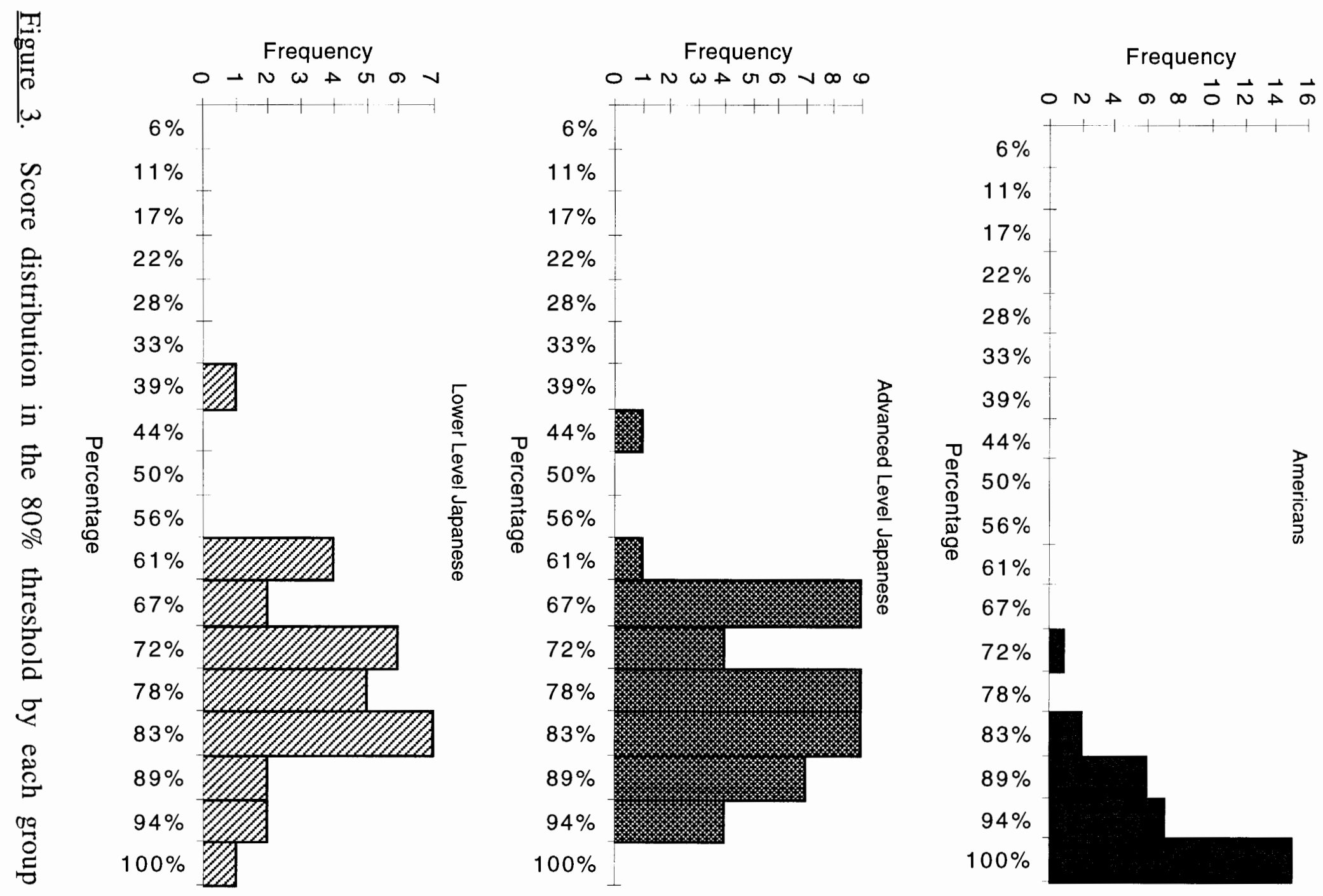
particular type of intonation are shown in Figure 4. These three groups' distribution curves appear to be very similar to those for all 40 questions as displayed in Figure 1.

Statistical analysis (see Table III) yielded a mean score for the American group of $25.2(83.9 \%)$, for the advanced level Japanese group of $18.4(61.2 \%)$ and for the lower level Japanese group of 17.8 (59.2\%). Standard deviations for the Americans, advanced level Japanese and lower level Japanese groups were 3.9, 3.0, and 3.3, respectively. While t-test results supported rejecting the hypotheses that the American group's mean score was equal to either of the Japanese groups' scores, the hypothesis that the mean scores of the Japanese groups were equal could not be rejected.

Analysis by $70 \%$ Validity Threshold. Nine paraphrase question pairs (18 sentences) met the $70 \%$ validity threshold. The score distributions of this subset for each of the three subject groups are shown in Figure 5. These graphic representations, as well as the descriptive statistic found in Table III, indicate a higher and more consistent level of performance by each group as compared to the results for the entire paraphrase questions set. Evaluation of the significance of the difference in mean score between each group was again based on t-tests. As with previous comparisons, the $\mathrm{t}$ statistics supported the conclusions that the American group performed at significantly higher level than either of the Japanese groups, and that there was no statistically significant difference in performance between the two Japanese groups. 


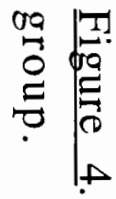

$\omega$ a or

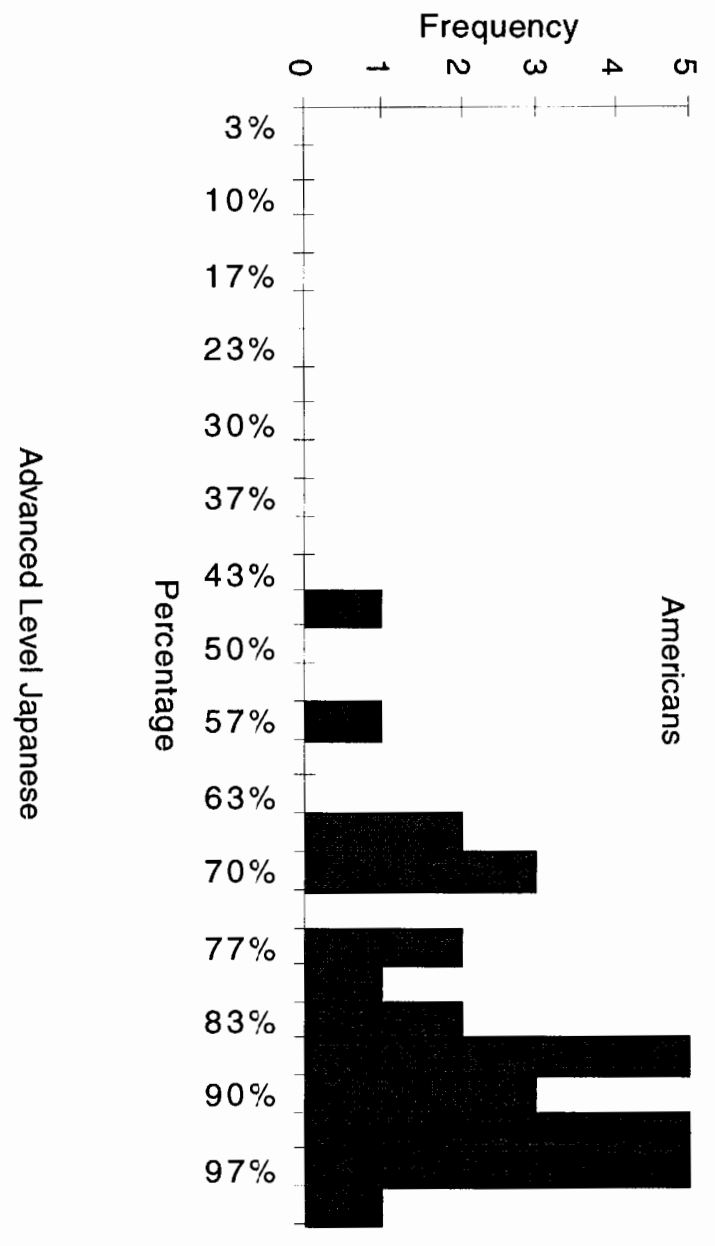


TABLE III

DESCRIPTIVE STATISTICAL SUMMARY OF PARAPHRASE INTONATION TYPE

\begin{tabular}{|l|c|c|c|}
\hline \multicolumn{1}{|c|}{ Subject Group } & Mean Score & $\begin{array}{c}\text { Relative } \\
\text { Score }\end{array}$ & $\begin{array}{c}\text { Standard } \\
\text { Deviation }\end{array}$ \\
\hline Total Question Set & 25.2 & $83.9 \%$ & 3.9 \\
American & 18.4 & $61.2 \%$ & 3.0 \\
Advanced Level & 17.8 & $59.2 \%$ & 3.3 \\
Lower Level & & & \\
70\% Validity Threshold Subset & 16.2 & $90.1 \%$ & 2.3 \\
American & 11.9 & $65.9 \%$ & 2.4 \\
Advanced Level & 11.4 & $63.2 \%$ & 2.8 \\
Lower Level & & & 1.1 \\
$80 \%$ Validity Threshold Subset & 9.4 & $94.2 \%$ & 1.5 \\
American & 7.3 & $73.2 \%$ & 1.8 \\
Advanced Level & 7.1 & $70.7 \%$ & \\
Lower Level & &
\end{tabular}

Analysis by $80 \%$ Validity Threshold. Five question pairs (10 sentences) qualified at the $80 \%$ validity threshold. Performance distributions of each subject group for this question subset are displayed in Figure 6. These distributions as well as the corresponding descriptive statistics (see Table III) show stronger and more consistent performance by all subject groups relative to the $70 \%$ validity threshold subset. Based on t-tests, score data again supported a conclusion that the American subjects group performed at a significantly higher level than either of the Japanese subject groups. As in previous analyses, the differences in the mean scores of the two Japanese groups were not statistically significant. 

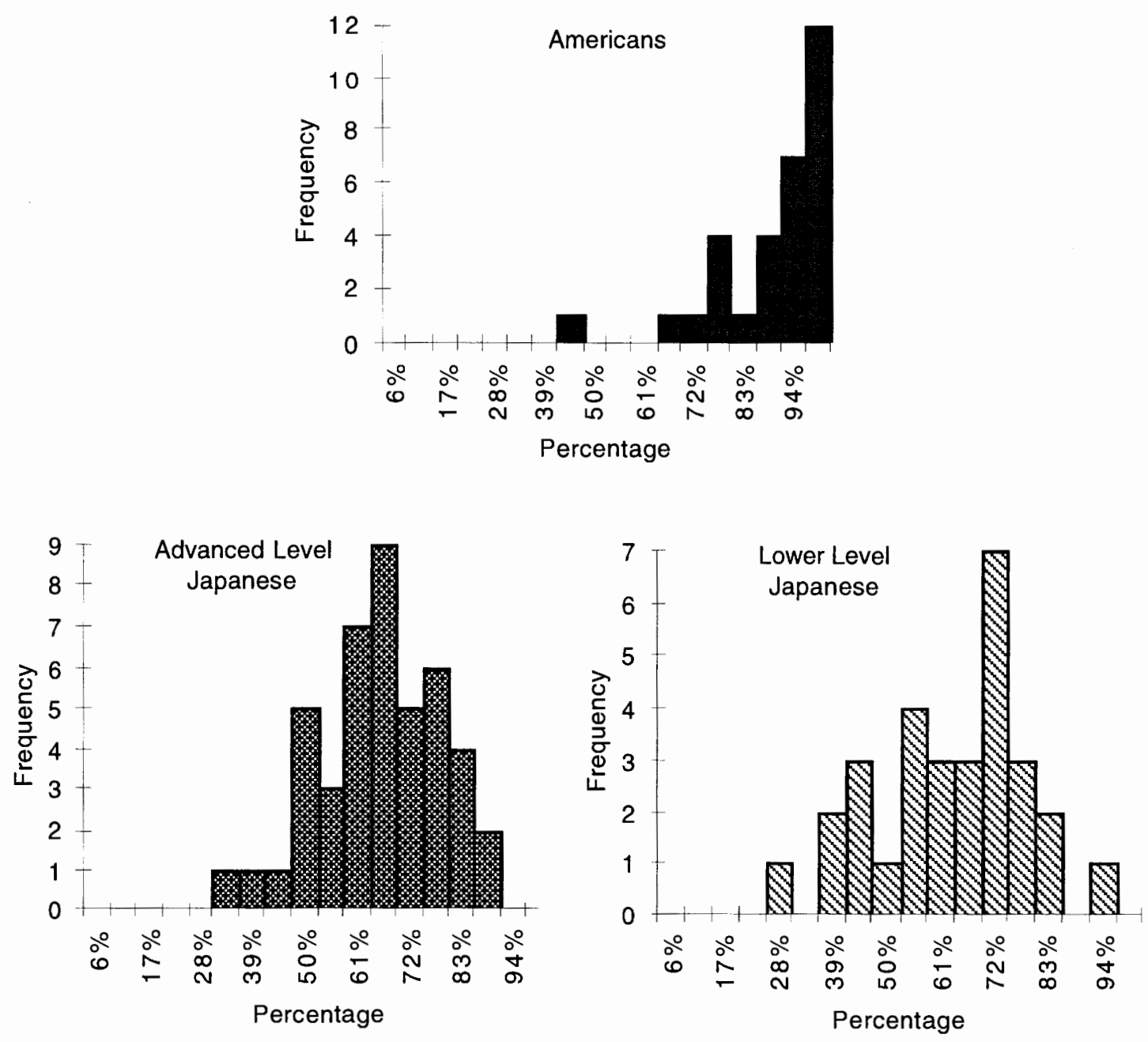

Figure 5. Score distribution for paraphrase intonation type of each group at the $70 \%$ validity threshold.

Overall Performance of Categorization. Three question pairs (six sentences) demonstrated this type of intonation. Figure 7 illustrates the score distributions of the three subject groups. Unlike the paraphrase set, where no Japanese subjects answered all the questions correctly, five of the advanced level and four of the lower level subjects answered all of the categorization questions correctly.

The mean score of the American group was $5.2(87.1 \%)$ out of 


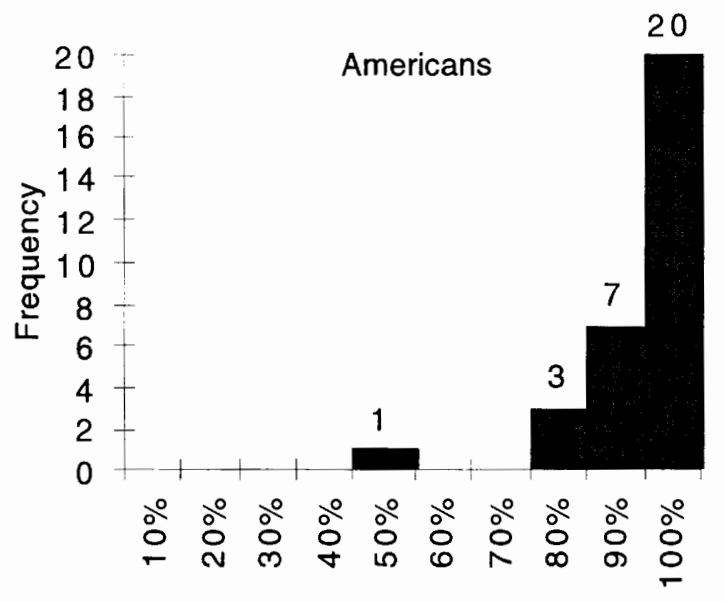

Percentage
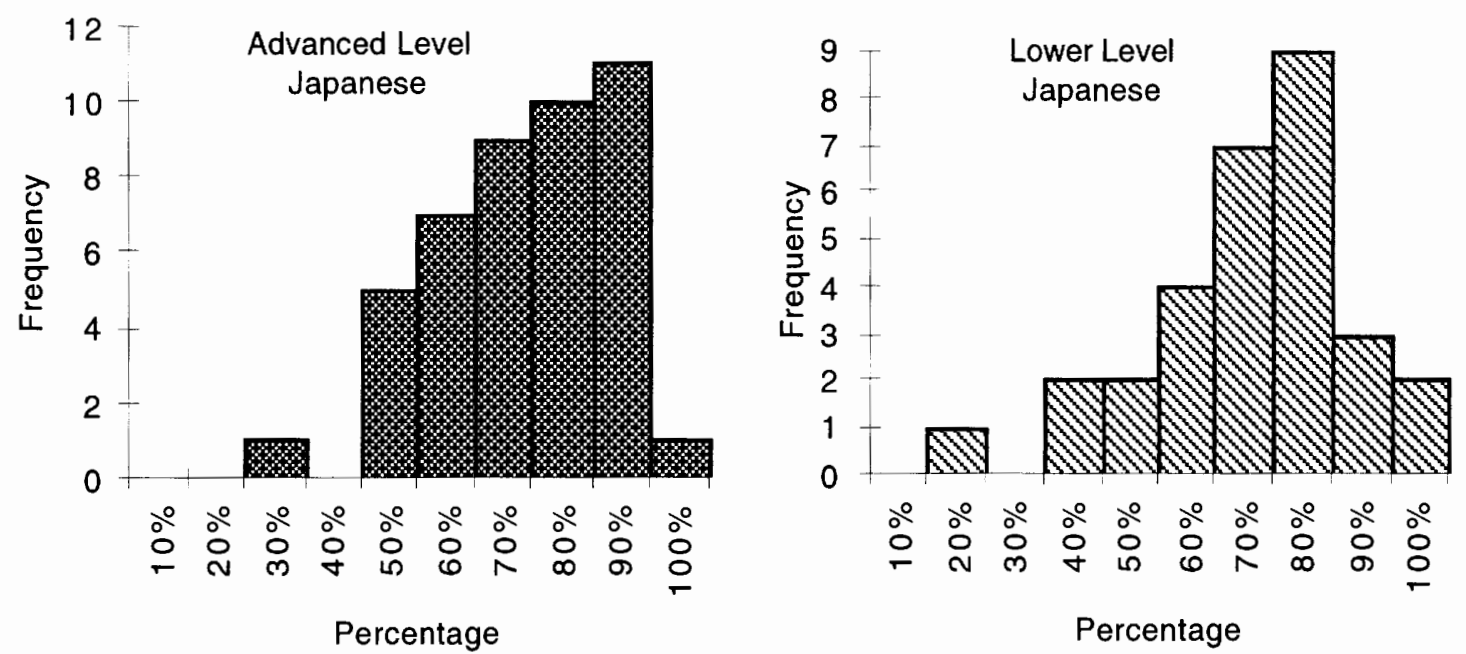

Figure 6. Score distribution for paraphrase intonation type of each group at the $80 \%$ validity threshold.

six, that of the advanced level Japanese group, 3.7 (63.3\%), and that of the lower level Japanese group, 4.1 (68.3\%). The standard deviations were $0.7,1.2$, and 1.2 , respectively. Based on t-tests, the difference in mean scores of the American group and that of each of the Japanese groups proved significant. Interestingly, the mean score of the lower level group exceeded that of the advanced level group. However, t-test results did not indicate that this difference was significant. 


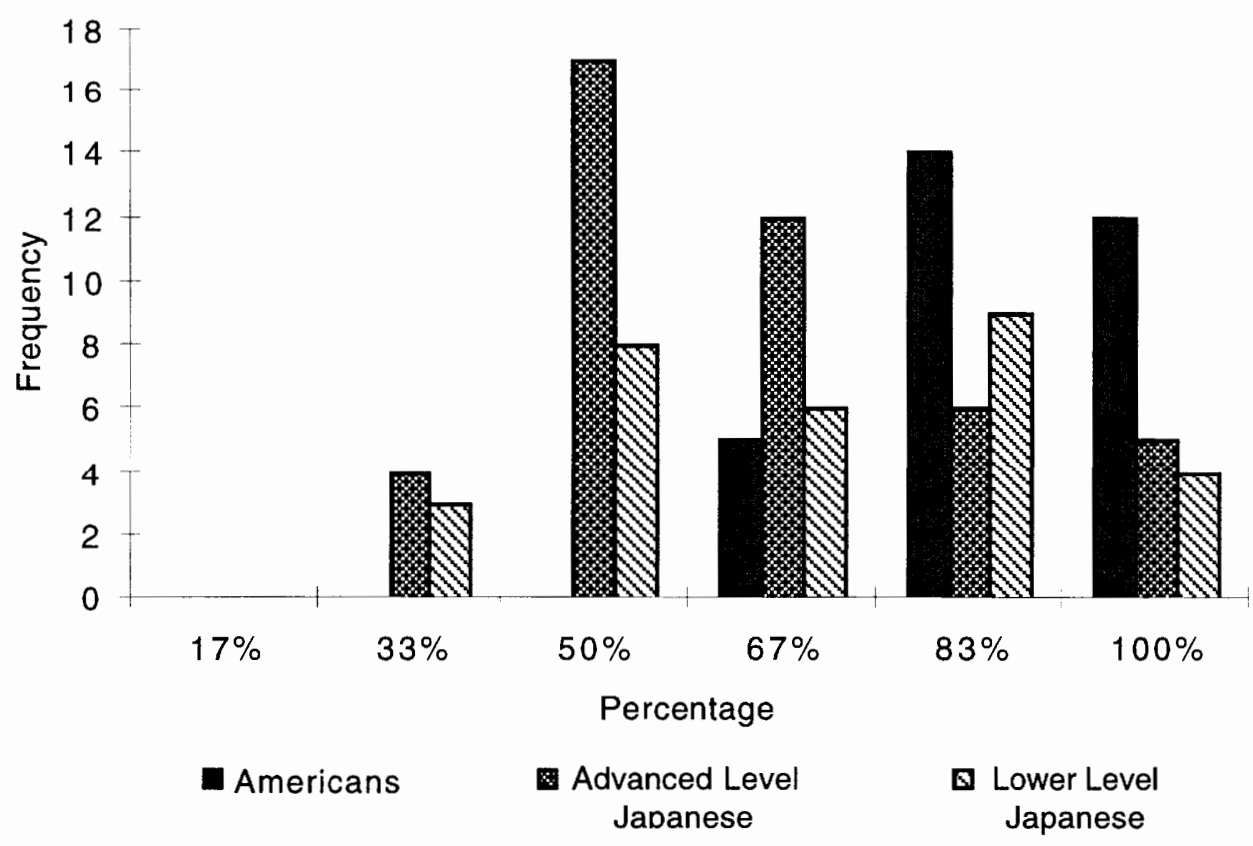

Figure 7. Score distribution for categorization intonation type.

Analysis of $70 \%$ and $80 \%$ Validity Threshold Subsets. As described in Chapter III, 2 categorization pairs (four sentences) fulfilled both $70 \%$ and $80 \%$ validity thresholds. Figure 8 depicts the score distributions of the three groups. As a whole, little change can be seen in the Figure 8 in comparison with the Figure 7.

The results of t-tests again supported that there exists a significant difference between the American group and the advanced and the lower level Japanese groups, but not between the two Japanese groups. The mean score of the American group was 3.7 (93.5\%) out of four, that of the advanced level Japanese group, 2.8 (69.9\%), and that of the lower level Japanese group, 3.0 (74.2\%). As before, the Japanese subjects did have difficulty with categorization and the difference in ESL levels did not affect their degree of comprehension. 


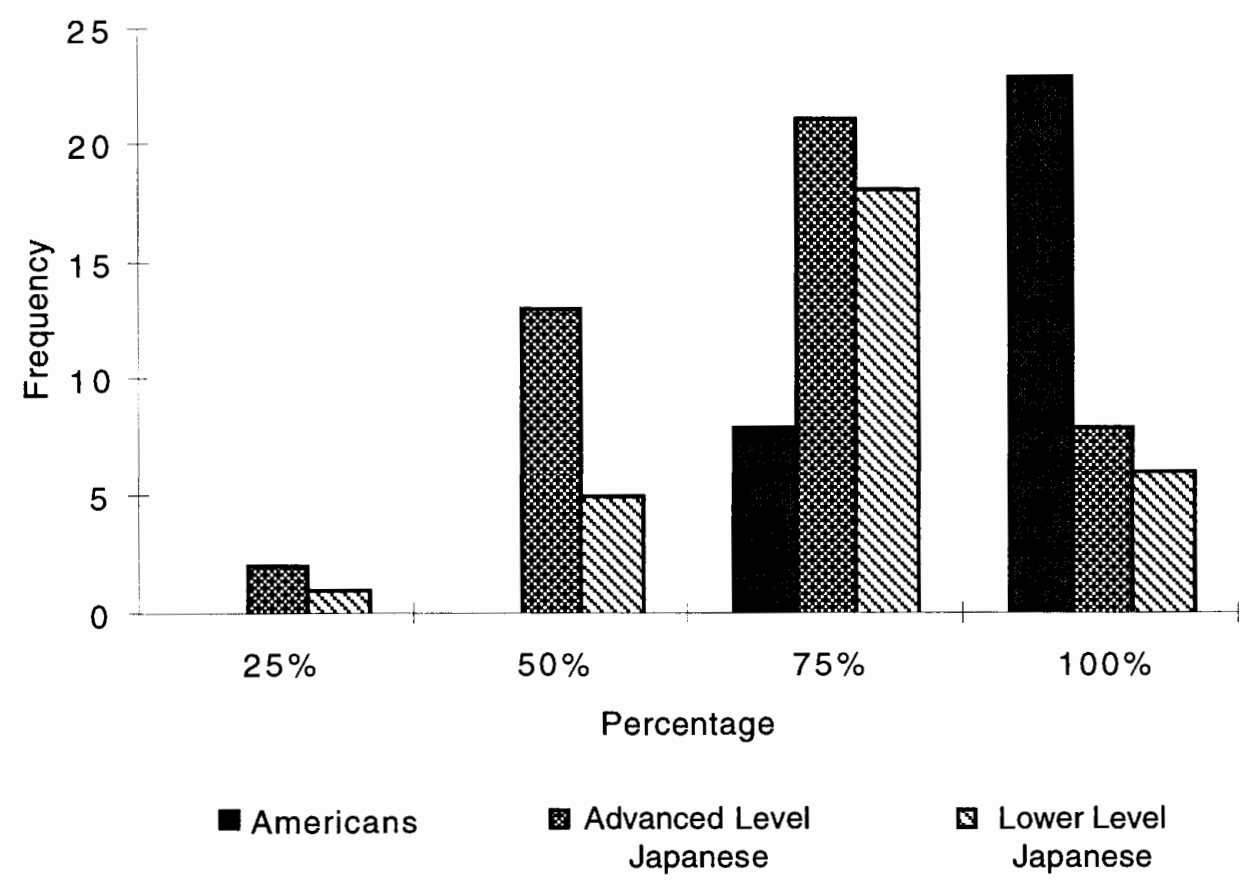

Figure 8. Score distribution for categorization intonation type at the $70 \%$ and $80 \%$ thresholds.

Overall Performance of Attitudinal Judgments. The number of analyzed attitudinal judgment sentences were four (2 pairs). As far as this particular intonation type is concerned, no threshold was necessary since the correct answers of the American group for each of the pairs exceeded $90 \%$. Figure 9 shows the score distribution on attitudinal judgment questions for the three groups. Unlike previous distributions, these three groups seem to have similar distribution curves. What is more, the advanced level Japanese group appears to attain higher scores than the other two groups.

The outcome of the t-tests clearly indicated that the Japanese subjects can comprehend this intonation type, attitudinal judgments, as well as native American English speakers do. The mean score of the American group is $3.87(96.8 \%)$ out of four questions, that of the 


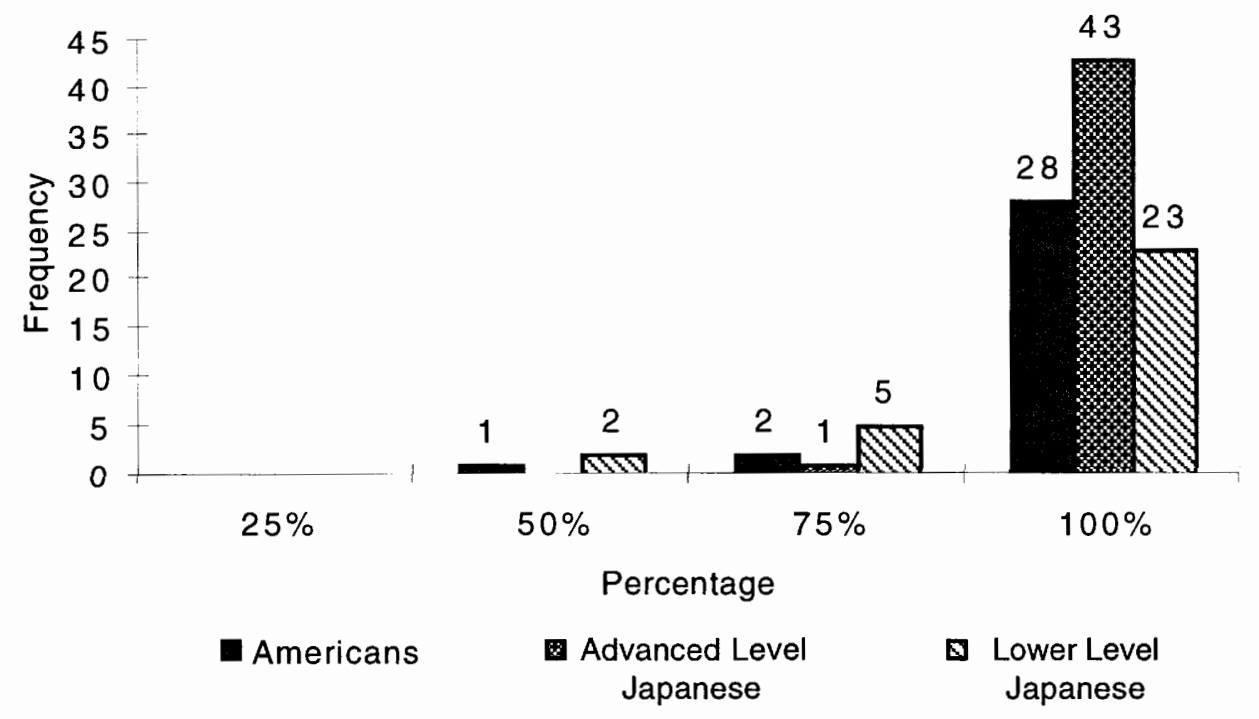

Figure 9. Score distribution for attitudinal judgments intonation type advanced level Japanese group, $3.97(99.3 \%)$, and that of the lower level Japanese group, $3.70(92.5 \%)$. The t-tests, at an $\alpha=0.05$ significance level, led to the conclusion that there is no significant difference between the American group and the two Japanese groups. However, there exists a significant difference between the advanced and lower level Japanese groups.

Closely looking at the test questions, by dividing them by intonation type, revealed that Japanese learners of English can understand a particular type of intonation, namely attitudinal judgments, as well as native English speakers. For the other two types of intonation (paraphrase and categorization) test results demonstrated a significant difference in understanding between the American group and either of the two Japanese groups. However, ttest analysis did not support a conclusion that there was any difference between the two Japanese groups in their ability to understand these types of intonation. This lack of distinction 
between the two Japanese groups prompted further examination from the perspective of contrastive variations of intonation. These results are presented in the following section.

\section{Contrastive Variations of Intonation}

As discussed in Chapter III, two kinds of analyses were employed. One was from the perspective of subjects' consistency in answering contrastive pairs. The other was from the aspect of their error patterns. These analyses made it possible to gain additional insight from their incorrect responses.

Consistency in Understanding of Contrastive Intonation Pairs. For each question, subjects who answered one contrastive variation correctly were first counted and then the number who answered other variation of the pair correctly were counted and expressed as a percentage of the former. This analysis reveals what percentage of the Japanese subjects differentiated and understood variations of intonation. The results of the American subjects were also presented as a reference. Each contrastive pair was separately examined, and the results were divided by type of intonation (paraphrase, categorization, attitudinal judgments) in order to identify possible relationships based on type of intonation.

\section{Paraphrase}

For the set of paraphrase question pairs, Table IV shows, by subject group, the number and percentage of subjects who answered correctly both questions, one question, and at least one question. These results indicate a rather wide variation in performance by the 
TABLE IV

\section{PROPORTION OF CORRECT RESPONSES BY EACH CONTRASTIVE VARIATION PAIR (PARAPHRASE):}

\begin{tabular}{|c|c|c|c|c|c|}
\hline Question Pair & Ame & \multirow{2}{*}{\multicolumn{2}{|c|}{$\begin{array}{l}\text { Advanced Level } \\
\text { (44 Sublects) }\end{array}$}} & \multicolumn{2}{|c|}{ Lower Level } \\
\hline $2-22$ & (31 Subjects) & & & $(30$ & Subjects) \\
\hline Both Correct & $60.7 \%$ & 27 & $67.5 \%$ & 18 & $81.8 \%$ \\
\hline Only 1 Correct & $39.3 \%$ & 13 & $32.5 \%$ & 4 & $18.2 \%$ \\
\hline At Least 1 Correct & $28: 100.0 \%$ & 40 & $100.0 \%$ & 22 & $100.0 \%$ \\
\hline $\begin{array}{l}\text { 'Question Pair } \\
3-23\end{array}$ & $\begin{array}{c}\text { Americans } \\
(31 \text { Subjects) }\end{array}$ & $\begin{array}{l}\text { Adve } \\
(44\end{array}$ & $\begin{array}{l}\text { inced Level } \\
\text { Subjects) }\end{array}$ & $\begin{array}{l}\text { LO } \\
130\end{array}$ & $\begin{array}{l}\text { wer Level } \\
\text { Subjects) }\end{array}$ \\
\hline Both Correct & $77.4 \%$ & 16 & $43.2 \%$ & 6 & $30.0 \%$ \\
\hline Only 1 Correct & $22.6 \%$ & 21 & $56.8 \%$ & 14 & $70.0 \%$ \\
\hline At Least 1 Correct & $31: 100.0 \%$ & 37 & $100.0 \%$ & 20 & $100.0 \%$ \\
\hline $\begin{array}{c}\text { Question Pair } \\
4-24\end{array}$ & $\begin{array}{c}\text { Americans } \\
\text { (31 Subjects) }\end{array}$ & $\begin{array}{l}\text { Adve } \\
144\end{array}$ & $\begin{array}{l}\text { inced Level } \\
\text { Subjects) }\end{array}$ & $\begin{array}{l}\text { Lo } \\
(30\end{array}$ & $\begin{array}{l}\text { wer Level } \\
\text { Subjects) }\end{array}$ \\
\hline Both Correct & $65.5 \%$ & 28 & $73.7 \%$ & 13 & $59.1 \%$ \\
\hline Only 1 Correct & $34.5 \%$ & 10 & $26.3 \%$ & 9 & $40.9 \%$ \\
\hline At Least 1 Correct & $29: 100.0 \%$ & 38 & $100.0 \%$ & 22 & $100.0 \%$ \\
\hline $\begin{array}{l}\text { Question Pair } \\
5-25\end{array}$ & $\begin{array}{c}\text { Americans } \\
(31 \text { Subjects) }\end{array}$ & $\begin{array}{l}\text { Adv: } \\
(44\end{array}$ & $\begin{array}{l}\text { inced Level } \\
\text { Subjects) }\end{array}$ & & $\begin{array}{l}\text { wer Level } \\
\text { Subjects) }\end{array}$ \\
\hline Both Correct & $90.3 \%$ & 29 & $70.7 \%$ & 23 & $82.1 \%$ \\
\hline Only 1 Correct & $9.7 \%$ & 12 & $29.3 \%$ & 5 & $17.9 \%$ \\
\hline At Least 1 Correct & $31: 100.0 \%$ & 41 & $100.0 \%$ & 28 & $100.0 \%$ \\
\hline $\begin{array}{l}\text { *Question Pair } \\
7-27\end{array}$ & $\begin{array}{c}\text { Americans } \\
(31 \text { Subjects) }\end{array}$ & $\begin{array}{l}\text { Adv: } \\
(44\end{array}$ & $\begin{array}{l}\text { nced Level } \\
\text { Subjects) }\end{array}$ & & $\begin{array}{l}\text { wer Level } \\
\text { Subjects) }\end{array}$ \\
\hline Both Correct & $87.1 \%$ & 5 & $14.3 \%$ & 4 & $20.0 \%$ \\
\hline $\begin{array}{c}\text { Only } 1 \text { Correct } \\
\text { At Least } 1 \text { Correct }\end{array}$ & $\begin{array}{c:r}4 & 12.9 \% \\
31 & 100.0 \% \\
\end{array}$ & $\begin{array}{l}30 \\
35 \\
\end{array}$ & $\begin{array}{r}85.7 \% \\
100.0 \% \\
\end{array}$ & $\begin{array}{l}16 \\
20\end{array}$ & $\begin{array}{r}80.0 \% \\
100.0 \% \\
\end{array}$ \\
\hline $\begin{array}{l}\text { Question Pair } \\
8-28\end{array}$ & $\begin{array}{c}\text { Americans } \\
\text { (31 Subjects) }\end{array}$ & $\begin{array}{l}\text { Adve } \\
(44\end{array}$ & $\begin{array}{l}\text { inced Level } \\
\text { Subjects) }\end{array}$ & $\begin{array}{r}\text { Lo } \\
(30 \\
\end{array}$ & $\begin{array}{l}\text { wer Level } \\
\text { Subjects) }\end{array}$ \\
\hline Both Correct & $\begin{array}{l:l}26 & 86.7 \%\end{array}$ & 25 & $71.4 \%$ & 18 & $72.0 \%$ \\
\hline Only 1 Correct & $13.3 \%$ & 10 & $28.6 \%$ & 7 & $28.0 \%$ \\
\hline At Least 1 Correct & $30: 100.0 \%$ & 35 & $100.0 \%$ & 25 & $100.0 \%$ \\
\hline $\begin{array}{c}{ }^{*} \text { Question Pair } \\
9-29\end{array}$ & $\begin{array}{c}\text { Americans } \\
\text { (31 Subjects) }\end{array}$ & $\begin{array}{l}\text { Adv } \\
(44\end{array}$ & $\begin{array}{l}\text { inced Level } \\
\text { Subjects) }\end{array}$ & $\begin{array}{r}\text { Lo } \\
130 \\
\end{array}$ & $\begin{array}{l}\text { wer Level } \\
\text { Subjects) }\end{array}$ \\
\hline $\begin{array}{l}\text { Both Correct } \\
\text { Only } 1 \text { Correct }\end{array}$ & $\begin{array}{r}93.5 \% \\
6.5 \%\end{array}$ & $\begin{array}{c}34 \\
8\end{array}$ & $\begin{array}{l}81.0 \% \\
19.0 \%\end{array}$ & $\begin{array}{c}20 \\
9\end{array}$ & $\begin{array}{l}69.0 \% \\
31.0 \%\end{array}$ \\
\hline At Least 1 Correct & $31: 100.0 \%$ & 42 & $100.0 \%$ & 29 & $100.0 \%$ \\
\hline $\begin{array}{c}\text { "Question Pair } \\
10-30\end{array}$ & $\begin{array}{l}\text { Americans } \\
\text { (31 Subjects) }\end{array}$ & $\begin{array}{l}\text { Adve } \\
(44\end{array}$ & $\begin{array}{l}\text { inced Level } \\
\text { Subjects) }\end{array}$ & $\begin{array}{l}\text { Lo } \\
130\end{array}$ & $\begin{array}{l}\text { wer Level } \\
\text { Subjects) }\end{array}$ \\
\hline Both Correct & $\begin{array}{l:l}19 & 61.3 \%\end{array}$ & 8 & $27.6 \%$ & 8 & $36.4 \%$ \\
\hline Only 1 Correct & $38.7 \%$ & 21 & $72.4 \%$ & 14 & $63.6 \%$ \\
\hline At Least 1 Correct & $31: 100.0 \%$ & 29 & $100.0 \%$ & 22 & $100.0 \%$ \\
\hline
\end{tabular}

Note: * indicates that a significant difference is found on the question. 
TABLE IV (CONTINUED)

\begin{tabular}{|c|c|c|c|c|c|c|}
\hline $\begin{array}{l}\text { Question Pair } \\
12-32\end{array}$ & \multicolumn{2}{|c|}{ Americans } & \multicolumn{2}{|c|}{$\begin{array}{l}\text { Advanced Level } \\
\text { (44 Subjects) }\end{array}$} & \multicolumn{2}{|c|}{ Lower Level } \\
\hline Both Correct & 22 & $75.9 \%$ & 14 & $42.4 \%$ & 9 & $39.1 \%$ \\
\hline Only 1 Correct & 7 & & 19 & $\%$ & 14 & $9 \%$ \\
\hline At Least 1 Correct & 29 & 100 & 33 & $100.0 \%$ & 23 & $100.0 \%$ \\
\hline $\begin{array}{c}\text { "Question Pair } \\
13-33\end{array}$ & \multicolumn{2}{|c|}{ Americans } & \multicolumn{2}{|c|}{$\begin{array}{l}\text { Advanced Level } \\
\text { ( } 44 \text { Subjects) }\end{array}$} & \multicolumn{2}{|c|}{$\begin{array}{l}\text { Lower Level } \\
\text { (30 Subjects) }\end{array}$} \\
\hline Both Correct & 21 & & 3 & $10.7 \%$ & 6 & $1 \%$ \\
\hline Only & 8 & & 25 & $\%$ & 17 & $9 \%$ \\
\hline At Least 1 Correct & 29 & 10 & 28 & $100.0 \%$ & 23 & $100.0 \%$ \\
\hline $\begin{array}{c}{ }^{*} \text { Question Pair } \\
14-34\end{array}$ & \multicolumn{2}{|c|}{$\begin{array}{c}\text { Americans } \\
\text { (31 Subjects) }\end{array}$} & \multicolumn{2}{|c|}{$\begin{array}{l}\text { Advanced Level } \\
\text { (44 Subjects) }\end{array}$} & \multicolumn{2}{|c|}{$\begin{array}{c}\text { Lower Level } \\
\text { (30 Subjects) }\end{array}$} \\
\hline orrect & 19 & $61.3 \%$ & 6 & $17.1 \%$ & 7 & $26.9 \%$ \\
\hline Only & 12 & & 29 & 82 & 19 & \\
\hline Correct & 31 & 10 & 35 & $100.0 \%$ & 26 & $0 \%$ \\
\hline $\begin{array}{c}{ }^{*} \text { Question Pair } \\
16-36\end{array}$ & \multicolumn{2}{|c|}{$\begin{array}{c}\text { Americans } \\
31 \text { Subjects) }\end{array}$} & \multicolumn{2}{|c|}{$\begin{array}{l}\text { Advanced Level } \\
\text { (44 Subjects) }\end{array}$} & \multicolumn{2}{|c|}{$\begin{array}{l}\text { Lower Level } \\
\text { (30 Subjects) }\end{array}$} \\
\hline orrect & 22 & & 20 & $51.3 \%$ & 11 & $42.3 \%$ \\
\hline Only & 7 & & 19 & 48. & 15 & $\%$ \\
\hline Correct & 29 & 100 & 39 & $100.0 \%$ & 26 & $100.0 \%$ \\
\hline $\begin{array}{c}{ }^{*} \text { Question Pair } \\
17.37\end{array}$ & \multicolumn{2}{|c|}{$\begin{array}{c}\text { Americans } \\
\text { (31 Subjects) }\end{array}$} & \multicolumn{2}{|c|}{$\begin{array}{l}\text { Advanced Level } \\
\text { (44 Subjects) }\end{array}$} & \multicolumn{2}{|c|}{$\begin{array}{l}\text { Lower Level } \\
\text { ( } 30 \text { Subjects) }\end{array}$} \\
\hline Both & 23 & $74.2 \%$ & 15 & $57.7 \%$ & 10 & $41.7 \%$ \\
\hline Only & 8 & & 11 & 42 & 14 & $3 \%$ \\
\hline Correct & 31 & 100 & 26 & $100.0 \%$ & 24 & $100.0 \%$ \\
\hline $\begin{array}{c}\text { Question Pair } \\
18-38\end{array}$ & \multicolumn{2}{|c|}{$\begin{array}{c}\text { Americans } \\
31 \text { Subjects) }\end{array}$} & \multicolumn{2}{|c|}{$\begin{array}{l}\text { Advanced Level } \\
\text { (44 Subjects) }\end{array}$} & \multicolumn{2}{|c|}{$\begin{array}{l}\text { Lower Level } \\
(30 \text { Subjects) }\end{array}$} \\
\hline Both & 12 & 54 & 13 & $41.9 \%$ & 9 & $56.3 \%$ \\
\hline Correct & 10 & & 18 & $58.1 \%$ & 7 & $8 \%$ \\
\hline 1 Correct & 22 & 100 & 31 & $100.0 \%$ & 16 & $100.0 \%$ \\
\hline $\begin{array}{l}\text { Question Pair } \\
20-40\end{array}$ & \multicolumn{2}{|c|}{$\begin{array}{c}\text { Americans } \\
\text { (31 Subjects) }\end{array}$} & \multicolumn{2}{|c|}{$\begin{array}{l}\text { Advanced Level } \\
\text { (44 Subjects) }\end{array}$} & $\begin{array}{l}\text { Lo } \\
130\end{array}$ & $\begin{array}{l}\text { wer Level } \\
\text { Subjects) }\end{array}$ \\
\hline Both & 28 & $90.3 \%$ & 34 & $81.0 \%$ & 20 & $80.0 \%$ \\
\hline Only 1 Correct & 3 & 9. & 8 & $19.0 \%$ & 5 & $20.0 \%$ \\
\hline At Least 1 Correc & 31 & $100.0 \%$ & 42 & $100.0 \%$ & 25 & $100.0 \%$ \\
\hline
\end{tabular}

three groups. For ten out of the fifteen question pairs, more than $70 \%$ of the American subjects who answered one question correctly also answered the other question correctly. This compares to only five of fifteen question pairs for the advanced group, and only four of the fifteen for the lower level group. 
Chi-square was used to assess whether these data evidenced a statistically significant association between the dimension of subject group and the dimension of answering correctly only one question or answering correctly both questions of a contrastive pair. For example, for question pair (2-22), the association of these two dimensions are represented by the values $17,27,18,11,13$, and 4 (see Table IV). Data of nine of the fifteen (60\%) paraphrase pairs provided statistically significant evidence of an association between the dimensions of subject group and the number of correct responses. The strength of these associations, as measured by Phi/Cramer's V, ranged from 0.24 to 0.69 with seven out of nine (78\%) at less than 0.50. As such, there is clear evidence of a weak to moderate association. However, when the group dimension is limited to only the two Japanese groups, the chi-square analysis offered no evidence of association between the two dimensions. One may therefore conclude that the ESL level of the Japanese subjects has no bearing on their ability to answer correctly one or both questions of a paraphrase contrastive pair.

\section{Categorization}

The results from the analysis of the categorization question subset were generally similar to those for the paraphrase subset (see Table V). For two of the three question pairs, more than $70 \%$ of the Americans who answered one question correctly also answered the contrastive question correctly. By comparison, both the advanced 
TABLE V

\section{PROPORTION OF CORRECT RESPONSES BY EACH CONTRASTIVE VARIATION PAIR (CATEGORIZATION)}

\begin{tabular}{|c|c|c|c|c|c|c|}
\hline $\begin{array}{c}\text { Question Pair } \\
1-21\end{array}$ & \multicolumn{2}{|c|}{ Americans } & \multicolumn{2}{|c|}{$\begin{array}{l}\text { Advanced Level } \\
\text { (44 Subjects) }\end{array}$} & \multicolumn{2}{|c|}{ Lower Level } \\
\hline Both Correct & 25 & $80.6 \%$ & 34 & $79.1 \%$ & 25 & $83.3 \%$ \\
\hline Only 1 Correct & 6 & $19.4 \%$ & 9 & $20.9 \%$ & 5 & $16.7 \%$ \\
\hline At Least 1 Correct & 31 & $100.0 \%$ & 43 & $100.0 \%$ & 30 & $100.0 \%$ \\
\hline $\begin{array}{c}\text { "Question Pair } \\
6.26\end{array}$ & \multicolumn{2}{|c|}{ Americans } & \multicolumn{2}{|c|}{$\begin{array}{l}\text { Advanced Level } \\
\text { (44 Subjects) }\end{array}$} & \multicolumn{2}{|c|}{$\begin{array}{c}\text { Lower Level } \\
\text { (30 Subjects) }\end{array}$} \\
\hline Both Correct & 29 & $93.5 \%$ & 9 & $24.3 \%$ & 7 & $25.9 \%$ \\
\hline Only 1 Correct & 2 & $6.5 \%$ & 28 & $75.7 \%$ & 20 & $74.1 \%$ \\
\hline At Least 1 Correct & 31 & $100.0 \%$ & 37 & $100.0 \%$ & 27 & $100.0 \%$ \\
\hline $\begin{array}{c}\text { Question Pair } \\
15-35\end{array}$ & ${ }^{A}$ & $\begin{array}{l}\text { nericans } \\
\text { Subjects) }\end{array}$ & \multicolumn{2}{|c|}{$\begin{array}{l}\text { Advanced Level } \\
\text { (44 Subjects) }\end{array}$} & \multicolumn{2}{|c|}{$\begin{array}{l}\text { Lower Level } \\
\text { (30 Subjects) }\end{array}$} \\
\hline Both Correct & $\overline{16}$ & $53.3 \%$ & 13 & $41.9 \%$ & 13 & $61.9 \%$ \\
\hline Only 1 Correct & 14 & $46.7 \%$ & 18 & $58.1 \%$ & 8 & $38.1 \%$ \\
\hline At Least 1 Correct & 30 & $100.0 \%$ & 31 & $100.0 \%$ & 21 & $100.0 \%$ \\
\hline
\end{tabular}

level and lower level subjects demonstrated a greater than $70 \%$ performance with only one question pair.

Again chi-square was used to determine if the data supported a conclusion of dependence between the dimension of subject group and that of a correct response to one or both question of a contrastive pair. Responses to only one (6-26) of the three contrastive pairs evidenced a statistically significant association. The strength of the association, phi $=0.64$, was moderate. With the subject group dimension limited to the two Japanese groups, the data did not support a conclusion of dependence between the two dimensions.

\section{Attitudinal Judgments}

As indicated in Table VI, all groups demonstrated a high level 
TABLE VI

PROPORTION OF CORRECT RESPONSES BY EACH CONTRASTIVE VARIATION PAIR (ATTITUDINAL JUDGMENTS)

\begin{tabular}{|c|c|c|c|c|c|c|}
\hline $\begin{array}{c}\text { "Question Pair } \\
11-31\end{array}$ & \multicolumn{2}{|c|}{$\begin{array}{c}\text { Americans } \\
31 \text { Subjects) }\end{array}$} & $\begin{array}{l}\text { Adve } \\
(44\end{array}$ & $\begin{array}{l}\text { nced Level } \\
\text { Subjects) }\end{array}$ & $\begin{array}{l}\text { Lo } \\
130\end{array}$ & $\begin{array}{l}\text { ver Level } \\
\text { Subjects) }\end{array}$ \\
\hline Both Correct & 29 & $93.5 \%$ & 44 & $100.0 \%$ & 25 & $83.3 \%$ \\
\hline Only 1 Correct & 2 & $\%$ & 0 & & 5 & $\%$ \\
\hline t Lea & 31 & & 44 & 10 & 30 & $\%$ \\
\hline $\begin{array}{c}\text { Question Pair } \\
19-39\end{array}$ & \multicolumn{2}{|c|}{ Americans } & \multicolumn{2}{|c|}{$\begin{array}{l}\text { Advanced Level } \\
\text { (44 Subjects) }\end{array}$} & \multicolumn{2}{|c|}{$\begin{array}{l}\text { Lower Level } \\
\text { (30 Subjects) }\end{array}$} \\
\hline Both & 29 & $\%$ & 43 & $97.7 \%$ & 26 & $86.7 \%$ \\
\hline Only 1 & 2 & $6.5 \%$ & 1 & 2.3 & 4 & $13.3 \%$ \\
\hline At Least 1 Correct & 31 & $100.0 \%$ & 44 & $100.0 \%$ & 30 & $100.0 \%$ \\
\hline
\end{tabular}

of understanding of intonation expressing attitudinal judgments. In particular, the advanced level Japanese group's performance exceeded that of the American group on both question pairs. As with the American group, all subjects of both Japanese groups answered at least one question of both contrastive pairs correctly.

Chi-square analysis did not support a conclusion that the subject group and correct response dimensions were associated. The findings were either statistically not significant, or the application of chi-square was inappropriated because more than $20 \%$ of the crosstabulation results had expected values of less than five.

Analysis of Error Patterns. As described in Chapter III, all the responses were classified into three categories: correct (C), appropriately wrong (AW), absolutely wrong (W). Figure 10 shows each group's score distribution of both $\mathrm{C}$ and AW (C\&AW) answers and only $\mathrm{C}$ answers. Though the distributions of $\mathrm{C}$ answers were 


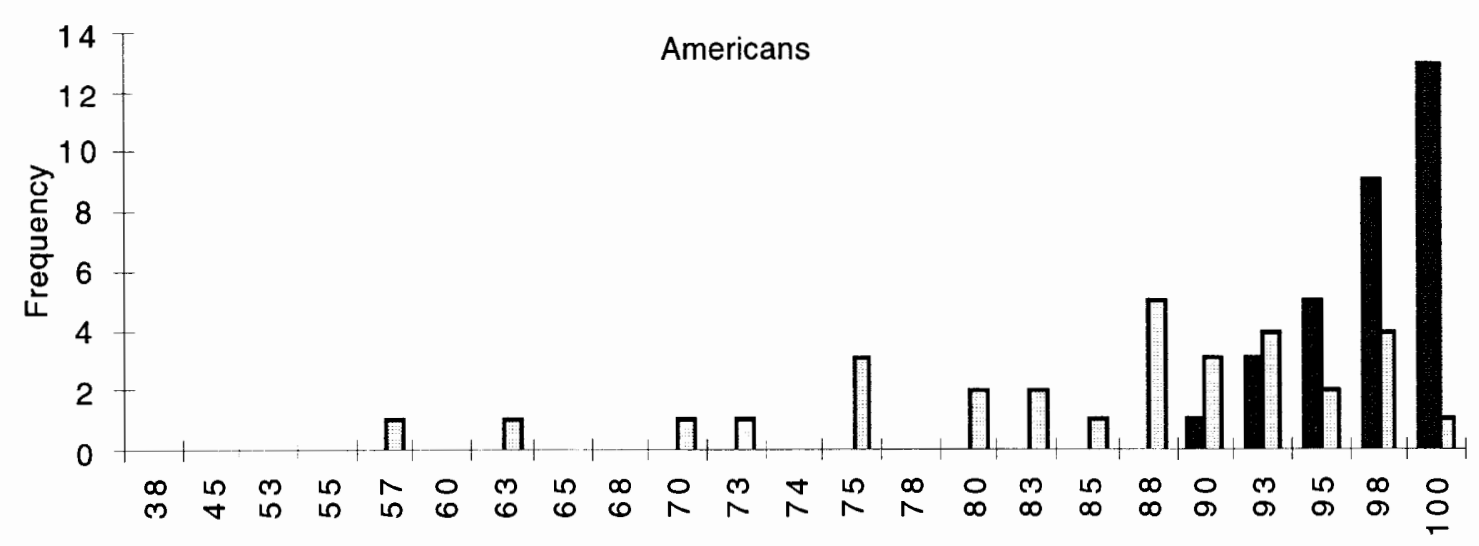

Percentage

- Correct \& Appropriately Wrong Answers

口Correct Answers

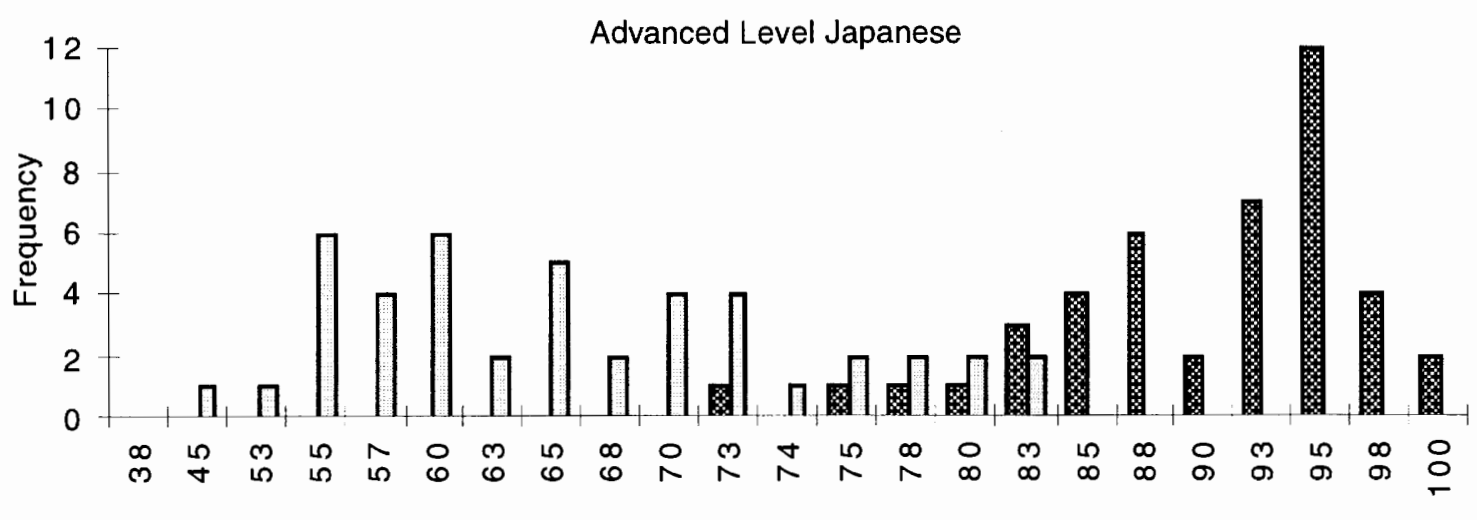

Percentage

- Correct \& Appropriately Wrong Answers

DCorrect Answers

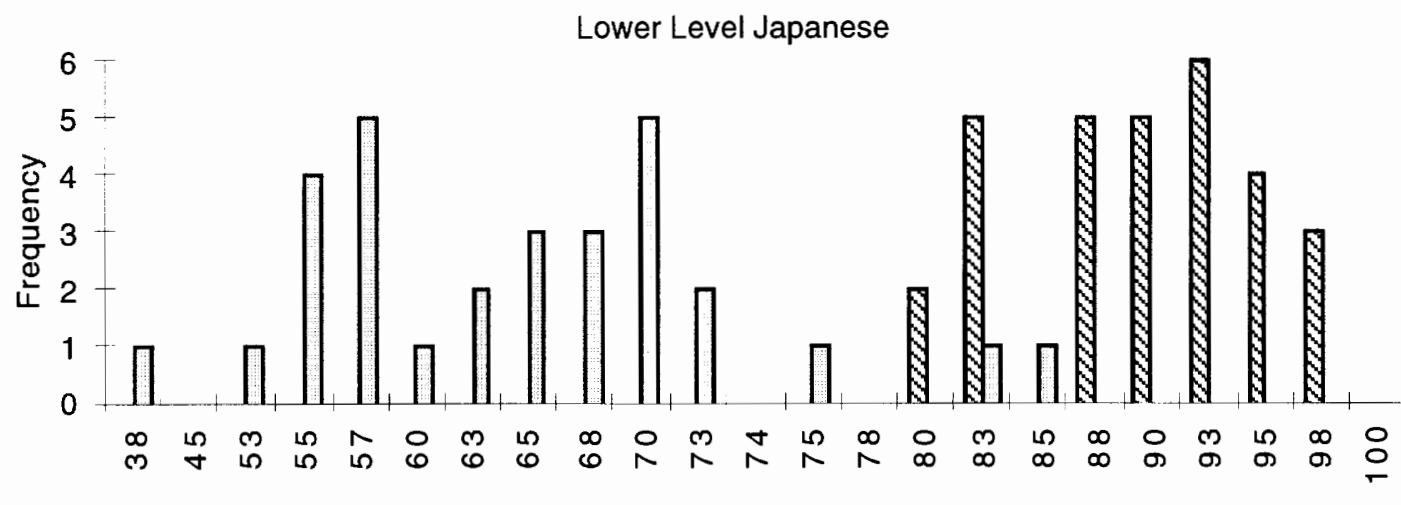

Percentage

D Correct \& Appropriately Wrong Answers

$\square$ Correct Answers

Figure 10. Score distribution of correct and appropriately wrong answers. 
examined previously, they are presented here for comparison. These combined distributions demonstrate the extent to which the subjects have at least a partial understanding of intonation. As one might expect, the American subjects chose very few W answers, answers which were either grammatically incorrect or out of context. The C\&AW distributions of both the Japanese groups indicate that these subjects, to a large degree, were at least aware of the intonation even if they often failed to interpret it correctly.

T-tests were used to compare the C\&AW scores of each group. The means and standard deviations for each group are found in Table VII. The results comparing the performance of the American group with either of the Japanese groups indicated that the difference in the means were significant. However, the same conclusion was not supported with regard to the two Japanese groups.

TABLE VII

DESCRIPTIVE STATISTICAL SUMMARY PERCENT CORRECT OR APPROPRIATELY WRONG

\begin{tabular}{|l|c|c|}
\hline Subject Group & Mean & $\begin{array}{c}\text { Standard } \\
\text { Deviation }\end{array}$ \\
\hline American & 97.4 & 2.8 \\
Advanced Level & 90.3 & 6.6 \\
Lower Level & 89.6 & 3.3 \\
\hline
\end{tabular}

Potential Variable Influencing Question Pairs. Despite the fact that the findings of analyzing contrastive variation of intonation are consistent with results of subjects' overall performance, there might 
be a potential variable regarding the order of pairs. After the first twenty questions, the other variation of each pair was placed in the same order as the first variations. The Japanese subjects, especially, had a tendency to do better on questions 21-40 than on questions 120. One possible explanation for this is that having heard the first

variation, interpretation of the second question was less ambiguous. Eliminating this variable would tend to lower the overall score of the Japanese subjects relative to the American subjects, but there is no indication that it would affect the relative performance of the two Japanese groups.

\section{Analysis of Other Potential Variables on Japanese Subjects}

In order to identify other variables that influence comprehension of intonation, the collected personal data for both Japanese groups (see Appendix D) were combined and analyzed. Five items (age, TOEFL score, length of current residence, length of time studying English, and length of other stays in English-speaking countries) were selected and analyzed.

Analysis of correlation coefficients did not reveal a statistically significant association between the Japanese subjects test scores and variables combining both length of stay in English speaking countries and the length of current residence in the USA. Additionally, a multiple linear regression model, based on all five variables, accounted for only $13.4 \%\left(\mathrm{r}^{2}\right)$ of the variation in score. It should be noted, however, that the TOEFL scores reported did not necessarily indicate the subjects' actual ESL level at the time the intonation test 
was conducted. Furthermore, it should be considered that with respect to length of time studying English, each subject's claim might not be consistent. For instance, some might have considered only formal types of English education, and some might have included self-study using, radio or TV programs for English learners or interaction with native English speakers. Since this kind of information is not readily verifiable, its reliability is questionable regardless of the results of statistical analysis.

\section{SUMMARY OF RESULTS}

Collected data of a comprehension test of English intonation taken by Japanese students, grouped by ESL level, were analyzed for the present study. The scope of analyses included overall performance, types of intonation, contrastive variation pairs, and other potential variables. A summary of main results is as follows:

1) Japanese students' overall performance indicated their difficulty with comprehending English intonation when compared to the American group. The score differences between American and Japanese students was found to be significant at an $\alpha=0.05$ level. Even at different validity thresholds, their relative difficulty was clearly evident. However, there was no basis to support a conclusion that there was any difference in performance between the two groups of Japanese subjects. 
2) All the questions used in this study were classified into three types of intonation, (paraphrase, categorization, and attitudinal judgments), and each type was separately examined. Only attitudinal judgments were found to be a type of intonation that Japanese students understood as well as the American students.

3) Contrastive variations in intonation were analyzed from two perspectives: consistency in understanding of contrastive intonation pairs, and error patterns. The consistency was studied by examining each question pair to see what percentage of Japanese students who answered one variation correctly also understood the other variation. On more than half of the questions, a significant difference was found between Americans and Japanese students. Again, there was no evidence to indicate that there was a statistically significant difference in the performance between the two groups of Japanese students. With respect to the latter, all the responses were divided into three categories (correct (C), appropriately wrong (AW), absolutely wrong (W) answers) and analyzed. The interpretation choice by Japanese students was found to be significantly different from that by Americans. That is, Japanese have a tendency to choose $\mathrm{W}$ interpretation more often than Americans. As before, the two Japanese groups did not exhibit a significant difference in performance. 


\section{CHAPTER V}

\section{DISCUSSION}

Based on the results of the present study, the features that cause Japanese students' difficulty in comprehending intonation are discussed in this chapter. Also discussed are possible explanations of how their weaknesses are related to English education in Japan.

\section{VALIDITY OF THE TEST}

\section{Potential Test Variables}

The first obstacle that arose in this study was that the performance of American students as a control unit was quite varied. As discussed in Chapter III, this was somewhat expected. The diversity of their performance, however, was found to exceed than the researcher had anticipated. Their performance plays a critical role of determining Japanese students' performance rate, so questions on which the control group did not do well could have been eliminated to enhance the validity of the test itself. However, instead of doing so, $70 \%$ and $80 \%$ validity thresholds were established.

The reason for this is that there might be other factors influencing native English speakers understanding of intonation. If 
such questions are simply eliminated, these factors might not be identified. Some speculations as to why the control group performed poorly on some questions follow.

One possible explanation is that an intonational system is so complex that there exists no standardized intonation pattern which always means the same. This complexity of intonation was already discussed in Chapter II. As Watanabe (1994) points out, for example, the statement sentence, "He is a lawyer," with a rising intonation, is not necessarily considered to be an interrogative utterance. It can be a surprised utterance. What determines a speaker's interpretation of such an intonation pattern without contexts stems from dialectal, individual, or some other differences. Lado (1961) warns about dialect differences when testing intonation. According to his explanation, although these differences are observed only in a few intonation patterns, an examiner needs to be aware of the fact that the test reflects a particular dialect. Though it is not clear if dialectic differences affected the performance of the American subject, it is unlikely considering that the test questions were reviewed by several applied linguists with this concern in mind.

Influences of non-linguistic variables might also explain why the score distribution of American group scored poorly on certain questions. Carroll (1968) points out that an examinee might not be able to perform well in a given circumstance, even if $s /$ he possesses adequate 'linguistic competence'. In listening and reading as well as speaking, it is difficult to test an individual's actual capability in these language skills (Carroll, 1968: 50). Hence, this might be the 
case with respect to the difficulties of some of the American students. In addition, poor performance might be attributed to a lack of motivation to take the exam. Also, some students might be nervous in a test atmosphere and could not perform at their best. Even if any of these non-linguistic variables affected their performance, these variables could also affect Japanese students' performance. These factors considered, it is therefore fair to say that whereas linguistic variables can threaten test validity, non-linguistic variables do not necessarily affect it since the latter is influential on any examinees in this study.

Specific Examples of Americans' Poor Performance

Closely looking at test sentences on which the American students did not perform well provides insight with respect to potential variables. In fact, an error pattern is evident, as can be seen from the following test sentences:

(2) I know Bill's son John/ and Harry

(22) I know Bill's, son/ John/ and 'Harry

(4) she dressed/ and fed the 'baby

(24) she dressed and fed the 'baby

(10) I didn't go out because I wanted to`see you

(30) I didn't go `out /because I wanted to`see you

(13) she won't drink vany coffee

(33) she won't drink'any coffee

(14) they've 'left / the children

(34) they've left the children 
(15) would you like tea/ or coffee

(35) would you like tea/ or coffee

(18) the children who were playing looked unhappy

(38) the children/ who were playing/ looked unhappy

Except for the question pair (13-33) and (15-35), these question pairs all include a pause which determines the meaning of the sentence. Though the question pair (15-35) is not a case in which a pause determines the meaning of the sentence, each question's length of pause may be somewhat differentiated by other intonation. Possibly, the difficulty that native speakers of English had in interpreting these sentences may be due to inconsistency in distinguishing pause length.

This is not surprising since pausing causes misunderstanding even in a conversation where people speak the same language. Tannen (1986) points out that conversational signals including pacing, pausing, loudness, pitch, and intonation depend much on individual habits and expectations. Another linguist, Wardhaugh (1992), explains that these signals are also culturally defined and their subtleties are learned in the group. Since these conversational signals are unconsciously employed, speakers are usually not aware of the difference between their signals and others'.

In a actual conversation, context can help speakers to avoid this kind of misunderstanding. They can ask and confirm if what they have heard is what they have interpreted. They might have visual aids, such as looking at the object that they are discussing. 
Therefore, for these sentences, intonation alone may not be sufficient to effect understanding.

\section{JAPANESE LEARNERS' ABILITY OF COMPREHENDING INTONATION}

\section{How Well Do Japanese Understand English Intonation?}

The results of the overall performance of all three groups indicate that Japanese learners of English can comprehend intonation up to certain point. The mean score percentage of advanced level Japanese students is $64.1 \%$ and that of lower level Japanese students, $63.0 \%$. Compared to that of American students, $85.6 \%$, it is quite evident that the level at which both of the Japanese groups comprehend intonation is significantly lower.

Though their respective performances improved to $78.3 \%$ and $76.8 \%$ for the $80 \%$ validity question set, they both fell far short of the comparative American performance of $94.6 \%$. Clearly, the ability of both Japanese subject groups to comprehend English intonation is significantly inferior to that of the native English speakers.

\section{Performance on Contrastive Variations}

Results of analysis regarding contrastive variations reflect on Japanese students' difficulty with English intonation. For ten of the twenty question pairs the Japanese students answered both question correctly less than $50 \%$ of the time. This indicates that for at least half of the question pairs the Japanese students could not correctly distinguish the contrastive difference in intonation. 


\section{Difficulties Due to Insufficient Grammatical Knowledge}

Although Japanese students' difficulty in understanding English intonation is apparent, part of it might stem from their insufficient knowledge of grammar, regardless of their ability to differentiate contrastive variations of intonation. As the findings from the analysis of the three groups' error patterns indicate, the Japanese students chose many more wrong answers than the American students. This implies that they had difficulty with grammar primarily rather than intonation on some of the questions.

One possible explanation for this is that some Japanese students did not know or misunderstood the grammatical construction of a sentence. Since all the interpretation was translated into Japanese, having chosen a W answer is not attributed to their ignorance of vocabulary or insufficiency of reading comprehension. They had a great difficulty with sentences, such as (6-26) 'didn't John enjoy it' and (13-33) 'she won't drink any coffee'. As to question (6), 16 of $44(36.4 \%)$ of the advanced level Japanese students and 12 of $30(40.0 \%)$ of the lower level Japanese student chose the $\mathrm{W}$ answer. For question (26), nine (20.5\%) of the former, three $(10.0 \%)$ of the latter chose the $\mathrm{W}$ answer (see Appendix E). The American students, on the other hand, only one $(3.2 \%)$ chose the $\mathrm{W}$ answer on both of the questions. With regard to the second question pair, three (6.8\%) of the advanced level Japanese students and four $(13.3 \%)$ of the lower level Japanese students chose the $\mathrm{W}$ answer on question (13) and seven (15.9\%) of the former, and four $(13.3 \%)$ of the latter chose the $\mathrm{W}$ answer on the question (33). 
However, none of the American students chose the $\mathrm{W}$ answer on the question (13) and only one (3.2\%), on the question (33). These percentages indicate that the Japanese students' choice of a W answer might have nothing to do with their ability of comprehending intonation.

Possibly they simply did not know that, depending on their intonational patterns, these sentences possess completely different meanings from their literal interpretations. Both of the question pairs include a negative indicator (didn't', 'won't) and if they are literally interpreted, they still hold the negation. However, question (6), with a falling intonation, and question (13), with a falling-rising intonation, are no longer negative sentences. Question (6) is an exclamation utterance which is interpreted that the speaker is expressing how great John's enjoyment was. However, as indicated above, many of the Japanese students misinterpreted this question as (b) 'the speaker is saying that John did not enjoy it'. Question (13) is a positive statement that means that she does drink coffee, but only particular kind. These types of interpretation are not wellknown to Japanese learners of English since they are rarely taught these aspects of intonation-grammar relationship. One reason that the percentages of Japanese students who chose the $W$ answer on the question pair (6-26) is much greater than the question pair (13-33) is that the $\mathrm{W}$ answer for (6-26) as described above is rather similar to the literal interpretation of the sentence, not losing negation. On the other hand, the $\mathrm{W}$ answer for (13-33), (b) 'she prefers tea to coffee', includes the word 'tea' which was not uttered, so this could 
be less confusing than the $\mathrm{W}$ answer for (6-26). Moreover, this interpretation does not include negation, which might have help the Japanese students not to choose the $\mathrm{W}$ answer.

As described here, a number of possible variables can make it difficult to measure pure comprehension ability of intonation. Even so, more detailed analyses can answer why Japanese learners of English have difficulty in understanding intonation and what causes the difficulty. In the next section, their strengths and weaknesses are discussed to attempt to discover whether their difficulty arises randomly or systematically.

\section{STRENGTHS AND WEAKNESSES OF JAPANESE STUDENTS}

\section{Performance Relative to Intonation Pattern}

Analysis by three types of intonational patterns indicate a general relationship between patterns of intonation and the performances of the Japanese students. For example, they can comprehend attitudinal judgment types of intonation as well as native speakers of English; however with respect to the other intonation types (paraphrase and categorization), they have great difficulty. The following discussion examines the details of intonation patterns from the perspective of the strength and weakness of the performances of the Japanese subjects.

Strengths. As mentioned earlier, both groups of Japanese students demonstrated a high level of comprehension of the 
attitudinal judgment type of intonation pattern. The question pairs of this type of intonation,

(11) what are you doing here

(31) what are you'doing here

(19) John passed his êxams

(39) John passed his èxams

represent intonation patterns which are strongly related to the speaker's attitude or emotion.

One explanation of why the Japanese subjects performed well may be found in the number of similarities in intonation which carries a speaker's attitude or emotion in both English and Japanese (see Chapter II). The example cited by Abe (1955) explains the similarity between these two languages regarding attitudinal judgment types like question pair (11-31) (see Chapter II). As to question pair (19-39), when a speaker is expressing his/her surprise as (19), s/he tends to employ loudness with high pitch in Japanese as well. Thus, these similarities might contribute to Japanese students' good performance on attitudinal judgments.

The attitudinal judgment type of intonation might be separate from linguistic knowledge of English and rather universal, so Japanese students could use their knowledge of Japanese for judgments. However, in this study, there is not evidence to support this speculation. Further study dealing with speakers of other languages is needed to determine if this is true.

Other than attitudinal judgment types of intonation, Japanese students performed fairly well on some paraphrase and 
categorization questions. Questions that did not meet the $70 \%$ validity threshold will not be discussed here since it is doubtful whether such questions are good references for judgments of understanding intonation.

Three paraphrase questions and one categorization question fulfilled this condition. The paraphrase question pairs on which Japanese students did reasonably well are as below:

(5) I know' that sheep can swim

(25) I know that sheep can`swim

(8) he can't see`clearly

(28) he can't 'see/, clearly

(20) John hit Sam and then'he kicked him

(40) John hit Sam and then he`kicked him

These contrastive pairs require grammatical knowledge of English. On question pair (5-25), 41 out of $44(93.2 \%)$ of the advanced level Japanese students and 28 of $30(93.3 \%)$ of the lower level Japanese students answered at least one variation correctly, and 29 of 41 $(70.7 \%)$ and 23 of $38(82.1 \%)$, respectively, answered both questions correctly (see Table IV, Chapter IV). Whereas 'that' in (25) is a complementizer of the following noun clause and should be pronounced as its weak form [ðət], the one in (5) is a pronoun and because of the emphasis, it should be pronounced as its strong form [ðæt]. This difference changes not only the intonation contour of an utterance but also its meaning. That is, in (5) the speaker talks about one particular sheep, but in (25), sheep in general. With regard to the question pair $(8-28), 35$ of $44(79.5 \%)$ of the advanced level 
Japanese students and 25 of $30(83.3 \%)$ of the lower level Japanese students answered at least one variation correctly and 25 of 35 (71.4\%) and 18 of $25(72.0 \%)$, respectively, answered both variations correctly. While the adverb 'clearly' modifies the verb 'see' in (8), the one in (28) modifies the entire sentence. The former means that he can see, but not clearly whereas the latter means that it is clear that he cannot see at all. As to question pair (20-40), 42 of 44 $(95.5 \%)$ advanced level Japanese students and 25 of $30(83.3 \%)$ lower level Japanese students answered at least one variation correctly and 34 of $42(81.0 \%)$ advanced level and 20 of $25(80.0 \%)$ lower level students answered both variations correctly. While stress on both the subject pronoun and the object pronoun of the coordinating clause in (20) indicates that the former is not the same subject of the main clause, John, but Sam. In (40), on the other hand, stress is placed on the verb 'kicked' in the coordinating clause, which indicates that the two pronouns are old information and must refer to the same persons as the main clause.

Possibly two factors help Japanese students understand these questions well. One is that these grammatical items are commonly taught in Japan and they have no difficulty in understanding them. The other is that the difference in intonation is juxtaposed in each pair. These three pairs include a falling tone of high variant that might make it easier for them to differentiate two variations. This might be related to the fact that Japanese students are quite sensitive to pitch height. Watanabe's (1988) study which supports the hypothesis that Japanese students have a tendency to depend on 
high pitch when judging stress in an English utterance might partly explain their good performance on the above questions in the present study. In fact, pitch plays a more important role than length or loudness in Japanese as discussed in Chapter II. It is therefore not surprising that high pitch catches their attention. It is presumed that these two factors, grammatical knowledge and differentiation of intonational patterns, must occur together and neither individually, can affect Japanese students' good performances on the paraphrase questions.

One categorization question pair on which the Japanese students did fairly well is as follows:

(1) they've bought a new car

(21) they've bought a'new car

Forty-three (97.7\%) advanced level Japanese students and 30 (100\%) lower level Japanese students answered at least one variation correctly and $34(79.1 \%)$ and $25(83.3 \%)$ of these students, respectively, answered both variations correctly. This pair is easy for them to differentiate since Japanese also has similar intonational patterns to these, as Abe (1955) has noted. A rising intonation is often used at the end of interrogative utterance in Japanese. What is more, the use of a rising intonation in English is taught in school as early as seventh grade. It is therefore not surprising that Japanese students have no significant problems with these variations.

Weaknesses. Despite the strengths of Japanese students in comprehending some forms of intonation, a great number of weaknesses were observed. On nine paraphrase question pairs and 
one categorization question pair, a significant difference was found in comparison with the control group. The following are paraphrase question pairs with which they have problems:

(3) he also translated the book

(23) he also translated the book

On question pair (3-23), 37 (84.1\%) of the advanced level Japanese students and $20(66.7 \%)$ of the lower level Japanese students answered at least one variation correctly. Only $16(43.2 \%)$ of these advanced students and six (30.0\%) of these lower level Japanese students understood both variations (see Table IV). As explained in Chapter I, while the adverb 'also' modifies the subject pronoun 'he' in (3), its modification is placed on the verb 'translated' in (23). The number of students who chose the interpretation (c) 'he not only wrote the book but also translated the book' is high on both of the variations (see Appendix E). This might be attributed to the fact that quite a few of them may have lacked the knowledge that the adverb can modify a noun as well as a verb depending on its intonational pattern.

(7) she didn't get 'one present at Christmas (27) she didn't get òne present at, Christmas

With regard to question pair (7-27), 25 (79.5\%) Japanese advanced students and $20(66.7 \%)$ Japanese lower level students answered at least one variation correctly and only five (14.3\%) and four (20.0\%) of these, respectively, comprehended both variations. These numbers are extremely low, which indicates their great difficulty with this question pair. Above all, a large number of the Japanese 
students answered (a) 'she got no present at all at Christmas' for both variations. Presumably most of the students literally interpreted the sentence, regardless of the intonational cues. In addition, most of them might not know the grammatical fact that the negative indicator 'didn't' can modify part of speech other than a verb, in this case, the quantifier 'one'. As a matter of fact, this ambiguousness of grammatical structures is not usually instructed in Japanese classrooms. It is reasonable to expect that if they lack such knowledge, they would have difficulty understanding the questions.

(9) I thought she was`married

(29) I thought she was, married

Forty-two (95.5\%) of the advanced level Japanese students and twenty-nine $(96.7 \%)$ of the lower level Japanese students answered at least one variation correctly on question pair (9-29). Thirty-four $(81.0 \%)$ of the former and twenty $(69.0 \%)$ of the latter interpreted both intonational patterns correctly. Unlike the above two pairs, fewer of the subjects were confused by these variations. However, for question (29), though only $3.2 \%$ of the American students chose the appropriately wrong response, $18.2 \%$ of the advanced students and $16.7 \%$ of the lower level students made this choice. Similar to question pair (20-40), intonation of either old or new information is a key to the correct answer. In (9), 'married' is new information and stressed while it in (29) is old information and 'thought' is stressed instead. Although most of the Japanese students did not have grammatical difficulty, some of them could not differentiate the 
contrastive variations, or, they did not know which variation should go with which meaning even if they could differentiate them.

(10) I didn't go out because I wanted to `see you

(30) I didn't go `out /because I wanted to`see you

As to question pair (10-30), twenty-nine (65.9\%) advanced level Japanese students and twenty-two (73.3\%) lower level Japanese students answered at least one question correctly. Only eight (27.6\%) of the former and eight (36.4\%) of the latter understood both variations. The difference of intonational patterns determines what the negative 'didn't' modifies in the sentence. In (10) the negative modifies not only the verb phrase of the main clause, but also the verb 'see' of the subordinate clause. In (30), on the other hand, the negative only modifies the verb of the main clause. This contrastive pair also seemed to confuse the Japanese students. The majority of them chose the interpretation (c) 'I stayed home because I wanted to see you' for both of the questions. Again, their unfamiliarity of this particular meaning of the structure may have been a factor in their confusion. When students in Japan learn a subordinate clause with 'because', grammatical items regarding only the type of (30) are usually explained, and intonation is not addressed. Hence, Japanese students' difficulty in this pair was also expected.

(12) I think he's 'competent

(32) I think he's`competent

On the question pair (12-32), thirty-three (75.0\%) advanced level Japanese students and twenty-three (76.7\%) answered at least one variation correctly and fourteen (42.4\%) and nine $(39.1 \%)$ of such 
students respectively understood both variations. The number of students who chose the $\mathrm{W}$ answer is fairly high [20.5\% and $13.6 \%$ of the advanced level students for question (12) and (32), respectively, and $40 \%$ and $13.3 \%$ of the lower level students for question (12) and (32), respectively], compared to other question pairs, which indicates they had no idea of what the fall-rise intonation implies in this sentence. The meaning of a fall-rise tone in this case implies a statement limited by conditions. Researchers such as Watanabe (1994), Cruz-Ferreira (1987), Cruttenden (1986), and O'Connor and Arnold (1973) described the intonation called 'reservation'. Question 12 means that the speaker thinks he is competent, but something else worries the speaker about him. However, question (32) is a definite statement which implies that the speaker has no doubts about him. The Japanese students' difficulty with this question pair does not lie in grammar or sentence structure but rather intonation usage that is often arbitrary in each language.

(13) she won't drink vany coffee

(33) she won't drink`any coffee

Question pair (13-33) is one of the most difficult contrastive pairs for the Japanese students in this study. Twenty-eight (63.6\%) advanced level Japanese students and twenty-three (76.7\%) lower level Japanese students answered at least one variation correctly and only three $(10.7 \%)$ of the former and six $(26.1 \%)$ of the latter interpreted both variations correctly. Additionally, the majority of them chose the interpretation (a) 'she drinks no coffee at all' for both of the questions. As explained in Chapter I, it is intonation that determines 
whether the negative modifies a verb or a quantifier. This aspect of the interaction of negative and quantifier is local or unique to English. Cruz-Ferreira's (1987) study of Portuguese subjects led to a similar result concerning this particular structure, 'not ... any'. One possible explanation as to why the Japanese students performed very badly on these contrastive variations is that most of them were not aware of the alternative interpretation so that they merely interpreted the sentence through lexical items and chose the same option for both questions or guessed the other option, even if they could recognized the intonational difference of the variations. Another is that they were actually able to differentiate each variation, but failed to assign the correct interpretation to it. It seems to me that the former is more likely to be the case since instruction of the alternative interpretation are neglected in English education in Japan.

(14) they've 'left / the , children

(34) they've left the 'children

Although question pair (14-34) does not meet the $70 \%$ validity threshold, it will be discussed here since compared to the American group, a significant difference was found,. Thirty-five $(79.5 \%)$ advanced level Japanese students and twenty-six (86.7\%) lower level Japanese students answered at least one variation correctly and six (17.1\%) and seven (26.9\%) of these students, respectively, understood both variations. The number of the Japanese students who chose the interpretation (c) 'someone has left the children' is very high on both questions. This indicates the same error pattern. 
This interpretation is consistent with using only lexical means to determining the correct response; an approach which Japanese students would be prone to use if they could not discern or understand the intonation pattern. Though this type of inverted sentence (14) is found in Japanese, few of the Japanese subjects were able to assign the correct interpretations to each variation.

(16) she gave her 'dog biscuits

(36) she gave her $\operatorname{dog}^{`}$ biscuits

With respect to question pair (16-36), thirty-nine (88.6\%) advanced level Japanese students and twenty-six (86.7\%) lower level Japanese students answered at least one of the variations correctly. Twenty $(51.3 \%)$ and eleven $(42.3 \%)$ of these students, respectively, understood both variations. Compared to some other question pairs listed in this section, a fair number of the Japanese students were able to assign at least one variation to the correct interpretation. It is assumed that they did not have great difficulty with the syntactic structure, but with the intonational patterns. In (16), 'dog' plays an adjective role that is part of the noun phrase 'dog biscuits' and modifies the following noun, while ' $\mathrm{dog}$ ' in (36) is part of noun phrase 'her dog'. Some Japanese textbooks of English include this type of distinction, so some of the students might be familiar with it. Yet their confusion in the distinction between these two variations should not be ignored.

(17) he might have told me

(37) he 'might have told me 
The last paraphrase question pair on which the Japanese students performed poorly also deals with a grammatical structure unfamiliar to them. Twenty-six (59.1\%) advanced level Japanese students and twenty-four (80.0\%) lower level Japanese students answered at least one variation correctly, whereas fifteen $(57.7 \%)$ and ten $(41.7 \%)$ of these students, respectively, assigned both variations to the correct interpretations. As explained in Chapter I, the ambiguous modal 'might' has two possible interpretations, unfulfilled duty (= 'he should have told me, but he didn't) or possibility (= 'it is possible that he has told me, but I forgot). A number of the Japanese students assigned the interpretation of one variation to the other variation. In other words, they chose an AW answer for both questions.

Presumably, they knew these possible interpretations, which implies their familiarity with this syntactic structure. Their difficulty might arise from the fact that either they could not hear the difference in the two variations or they were able to discriminate one from the other, but unable to assign the correct interpretations to them.

(6) didn't John en 'joy it

(26) didn't John enjoy it

This question pair demonstrates categorization. Thirty-seven (84.1\%) advanced level Japanese students and twenty-seven (90.0\%) lower level Japanese students answered at least one variation correctly, but only nine (24.3\%) and seven (25.9\%) of those students, respectively, replied to both questions correctly. It is again speculated that due to their lack of familiarity with this syntactic structure, namely, an inverted exclamation, they were unable to 
assign the correct interpretations to these variations even if they were able to hear the distinction between the intonational patterns. Though their choices of interpretations for (6) were inconsistent, they consistently chose the correct response to (26) which was also the correct answer ('the speaker is asking if John enjoyed it') to the literal meaning of (26). This may indicate that most of the Japanese students could differentiate the two intonational patterns and answer the literal meaning correctly out of familiarity with a rising intonation for a question, but were unaware of an alternative interpretation and guessed the answer for (6). Otherwise, they could have chosen either the $\mathrm{C}$ or the AW response for both (6) and (26).

Close examination of Japanese students' strengths and weaknesses by each question pair demonstrate that there exist some patterns in their comprehension of English intonation Due to the difficulties of testing intonational competence, however, it is impossible to point out a single component that explains their poor performances. In order to further illustrate Japanese students' error patterns, the results of a similar study conducted by CruzFerreira (1987) will be compared and the similarities and differences between the present study and her study will be discussed.

\section{The Transfer Strategy}

Although the present study is not a replication of CruzFerreira's (1987) study as mentioned in Chapter I, the results of her 
study are comparable to the findings in this research. Cruz-Ferreira (1987) conducted a parallel study of native and nonnative performance of two groups of speakers, Portuguese and English, with respect to comprehension of intonation. Both of the groups were given in their L1 and L2 intonational tasks similar to the ones used in the present study. Since some of the questions used by Cruz-Ferreira were adopted for this study, it is possible to compare the two studies.

One of the findings of Cruz-Ferreira's (1987) study is that nonnative speakers employ 'the transfer strategy' "where the same intonational difference operates on a familiar structure in L1, the meaning conveyed by intonation in L1 is generalized to L2" (CruzFerreira, 1987: 115). According to her, there are two kinds of the transfer strategy: positive and negative. The case in which L2 interpretation through $\mathrm{L} 1$ is successfully made is considered to be the positive transfer, whereas the case in which L2 interpretation through L1 ended unsuccessfully is considered to be the negative transfer.

Three question pairs which exemplify the transfer strategy can be observed in this study. As the above discussion indicates, the performances of Japanese students on question pairs (1-21), (11-31) and (19-39) are believed to be the result of the positive transfer from $\mathrm{L} 1$ to $\mathrm{L} 2$. The first includes the contrast between a falling tone for interrogation and a rising tone for statement at the end of the utterance. The second deals with the contrast between 'rude' with a low-fall tone and 'neutral' with a high-fall tone. The third includes 
loudness associated with high pitch which is also observed in Japanese. No examples of negative transfer were identified.

\section{The Pitch Height Strategy}

Another strategy discussed by Cruz-Ferrira (1987) is 'the pitch height strategy'. This occurs "where the meaning contrast conveyed intonation in L2 can be associated with broadly similar uses of pitch contours or pitch height in L1, 'abstract' generalizations regarding meaning seem to be made, correlating higher overall pitch with 'openness' and lower pitch with 'finality'” (1987: 115). Japanese speakers' sensitiveness to pitch height was mentioned earlier with respect to Watanabe's (1988) study. Cruz-Ferreira (1987) also points out that nonnative speakers tend be sensitive to pitch contour or height.

This tendency can be observed in some of the question pairs. The results of question pairs (5-25), (8-28), and (10-20) are consistent with the pitch height strategy. All the pairs include a high-falling tone which is easy to recognize for Japanese students; therefore the pitch height strategy was positively applied. Although Cruz-Ferreira's (1987) comment regarding pitch height does not specify a particular type of pitch, Japanese students are especially sensitive to high pitch. Accordingly, the outcome of question pair (19-39) is possibly due to the use of a pitch height strategy, though the pair includes a high rise-fall tone, instead of a high fall tone. One question pair, however, seems to be an exception. Question pair (1636) also involves a high-falling tone, but the correct percentage is 
quite low. This cannot be explained by only the pitch height strategy and it might be related to grammatical issues that will be discussed next.

\section{The Lexico-syntactic Strategy}

The last strategy of nonnative comprehension of intonation described by Cruz-Ferreira (1987) is 'the lexico-syntactic strategy'. This strategy is employed "where certain lexical items or grammatical patterns of L2 are most commonly associated with an 'unmarked' meaning, this straightforward interpretation suggested by the words will tend to override a 'marked' interpretation which is highly intonation-dependent" (1987: 116). Cruz-Ferreira (1987) exemplifies 'not ... any' structures and inverted structures such as question pair (6-26) for the lexico-syntactic strategy. As mentioned before, speakers of Portuguese in her study also had great difficulty in assigning the correct interpretation. Moreover, they had a strong preference to interpret the utterances literally, that is, as straightforward negative and question, respectively. Crutz-Ferreira (1987) further explains:

This strategy operates on sentences, structures or items that can be said to have a strong 'first interpretation' or, to use Berkovits' term, a 'high-bias' interpretation.

Berkovitz (1981, 43) quantifies the notion of high-bias on the basis of 'the proportion of subjects who perceive a particular meaning first' in the reading of potentially ambiguous sentences. Berkovits defines the notion of high-bias in silent reading of sentences, that is, in sentences with 'no' intonation. Such high-bias interpretations of sentences seem to be made in listening 
too, where the non-natives interpret certain sentences as if they were spoken with no intonation (p. 116).

Even though, with respect to same potentially ambiguous sentences, similar results were observed for both the Japanese and Portuguese subjects it appears that the Japanese students' high percentages of choosing high-bias interpretations are due to their lack of knowledge of the grammar-intonation relationship rather than their tendency to perceive an utterance as an unmarked meaning. For all the paraphrase and categorization question pairs presented in the discussion of weaknesses, many of the Japanese students chose a high-biased interpretation. Though not many of them were confused on question pair (9-29), some of them misinterpreted the sentence with the alternative meaning for the high biased meaning and vice versa. On any of these question pairs, their percentage of correct responses for questions where a high biased interpretation was the correct answer is fairly high. For the other variations of these question pairs except for (6-26) and (1232 ), on the other hand, a number of the Japanese students chose a high biased interpretation for the answer and ended up having an incorrect answer. Additionally, especially for question pairs (6-26) and (12-32), a significant number chose the $\mathrm{W}$ answer. This indicates either their confusion in the grammatical structures or their lack of intonational knowledge as discussed earlier. If it was the case as explained by Cruz-Ferreira (1987), the Japanese students would have picked either a high biased or an alternative reply. Presumably, their primary problem lies in the fact that they have 
never been taught alternative interpretations other than high biased interpretations of such sentences as listed above. Regardless of associated intonation, there seems no choice for them but selecting a high biased interpretation for one variation and employing intelligent guess for the other, or filling in a high biased interpretation for both questions to ensure at least one correct response.

This conclusion is based on the feedback of some of the Japanese subjects who participated in this study. The same conclusion might also apply to the case of Portuguese students. It is unclear whether or not most of the Portuguese students were in fact aware of such alternative usage of 'not . . . any' structures and structures with inversion. These syntactic structures and associated intonation are local and characteristic of English, which make it difficult for non-native speakers to understand without knowledge of the relationship between syntactic structure and intonation. If they lack this knowledge, all they can do is to guess what an utterance means within their knowledge of L1 and what they have learned about L2.

Though Cruz-Ferreira's explanation accounts for the tendency of non-native speakers, who are aware of the high-biased interpretation as well as the alternative interpretation to choose the high-biased interpretation, it does not address the learning experience of the typical Japanese non-native speakers of English. Since alternative interpretations are not usually presented in the classroom, Japanese students' familiarity is limited to the high-biased 
interpretation. Consequently, their tendency to choose high-bias interpretations reflects a failing in teaching methodology rather than a preference for a more familiar high-biased response.

\section{Exceptions}

Some question pairs do not seem to be categorized into any of the three strategies. Question pair (14-34), for example, should fall into the positive transfer strategy since a similar structure is also observed in Japanese. However, the result for this question pair indicates that the Japanese students had great difficulty. The same question pairs were also used in the experiment of Cruz-Ferreira (1987). According to her, Portuguese has the same type of inverted structure as English, and the outcome was that Portuguese students had no problem with understanding the two variations. As such, this question pair exemplifies positive transfer. However, this is not the case for Japanese students. One possible explanation can be again attributed to their lack of grammatical knowledge in L2. It is assumed that they were aware of the similar structure in Japanese, but they have not encountered such a structure in English. Lacking such L2 awareness Japanese students are culturally adverse to pursuing intuitive associations which would lead to the selection of the alternative interpretation. Indeed, a great number of them chose the literal meaning for both questions.

Another question pair that does not seem to fit in any of the strategies is (12-32), which includes a fall-rise tone implying reservation. As explained in the weaknesses section, the Japanese 
students' difficulty in this question pair probably stems from their ignorance of what the intonation means rather than their confusion with syntactic structure. The structure, 'I think (thought) + a subordinate clause' used in question pair (9-29) and (12-32), is straightforward and they have no particular difficulty with it. Their choice of the $\mathrm{W}$ answer, especially when the alternative interpretation is the correct response, is rather high indicating that they randomly guessed. This problem thus arises from the fact that they are not aware of intonational functions which cannot be learned from written English. The fall-rise tone used in (12-32), for instance, retains a number of different implications depending on a situation. Unless they are aware of such implications, they can only guess at the meaning. The important point is that this is a different issue from grammatical matters, though, their solution, a random choice, is the same as when they had difficulty with syntactic structures.

Finally, despite the fact that question pair (16-36) should not be troublesome for Japanese students since it is a matter of the distinction in which a word receives a high-fall tone, they performed poorly. It is believed that Japanese students are able to differentiate this type of distinction easily because they are sensitive to high pitch. What is more, I assume that most of the students in this study were aware of the grammatical distinction as explained in the weaknesses section. What perplexed them might stem from there being two objects of the ditransitive verb 'give'. More specifically, since the word 'dog' is ambiguous and it can become either an adjective as in (16) 'dog biscuits' or a noun as in (36) 'her dog'. Their 
poor performance is largely due to the high degree to which they chose the high-bias interpretation as the AW response. This pattern is consistent with choosing the high-biased response for both questions is an attempt to ensure that at least one question would be answered correctly.

As can be seen from this discussion, there are a number of potential factors that make English intonation difficult for them. In most cases, more than one factor hindered their correct understanding of intonation. It is therefore impossible to determine exactly what causes their difficulty. One of the most significant factors is a lack of knowledge of how intonation influences grammar in English. Although there are other possibilities such as the preference of a high-biased interpretation, the absence of particular L2 intonation patterns in L1, and L1 interference, the results of analyzing differences of performance in the following section support this speculation.

\section{THE EFFECT OF DIFFERENT ESL LEVELS}

\section{More Advanced, More Competent?}

One of the purposes of the present study is to probe how the different ESL levels affect Japanese students' comprehension of intonation. The resarch hypothesis was that advanced level students would perform better than lower level students on the experiment. Though it seems reasonable to think that more advanced they are, better they can perform in comprehension of intonation, the findings 
of the study, however, indicate that there is no significant difference between the two groups of Japanese students in their overall performances.

The resultant implication is that there is something else affecting comprehension of intonation. One might speculate that the reason why no significant difference was observed between the advanced level and lower level Japanese students results from their insufficient knowledge of English intonation. If one's linguistic competence is zero, it is difficult to develop anything from there. More specifically, if language learners do not know what roles intonation plays in English, how intonation functions, or what intonation patterns are used under what circumstances, how do they develop such skills without any help? This would explain why total length of exposure in English did not correlate with the Japanese students' performances.

In addition, if learners lack linguistic competence, it is difficult to take advantage of the opportunities to benefit from increased exposure to L2. In general, the longer they are exposed to a target language, more opportunities to encounter a variety of its usage they have. However, even if they live in a country where the target language is spoken for eight or nine years, they cannot improve linguistic skills without self-awareness because they pay no attention to such input. Since no salient difference was found between the performance of the advanced level and that of the lower level Japanese students, they must lack linguistic competence regarding intonation. 


\section{Influence of Different ESL Levels on Attitudinal Judgments}

The only significant difference found between the two Japanese groups was in the attitudinal judgment type of intonation. What this finding implies is that the more advanced Japanese students are, the better they understand this particular type of intonation. Attitudinal judgments are also the only type of intonation that the Japanese students can comprehend as well as native English speakers. Furthermore, they can develop this skill even without any help as they become more advanced.

The reason why Japanese students can improve comprehension of intonation regarding attitudinal judgments is not clear. One possible explanation is that this type of intonation might be the easiest for them to perceive and develop by themselves since no grammatical issues are involved. Another possibility might stem from their sensitivity to one's attitude or emotion which is characteristic of Japanese culture. According to Triandis (1994), Japan is defined to be a high-context culture where one considers how the message is said is more important than what is actually said. It is therefore assumed that Japanese students soon get accustomed to intonational patterns implying a speaker's attitude or emotion as they are more exposed to English.

Attitudinal judgment type of intonation, in other words, can be learned without any instruction. Conversely, the other types of intonation, paraphrase and categorization, should be taught to them in order to lead them to the point at which they can consciously pay attention to such intonation usage that native English speakers use. 


\section{CAUSES OF DIFFICULTY}

\section{Teaching Intonation in Japan}

Except for intonation of attitudinal judgments that does not require the knowledge of grammar-intonation relationships, the Japanese students have great difficulty in comprehending English intonation. Since all the Japanese subjects were born in Japan and have gone through English education there, it is necessary to investigate how intonation is taught in Japanese classroom.

Although an overview of teaching English in Japan was described in Chapter II, more specific depiction focusing on intonation is appropriate. As mentioned before, oral or aural skills, not to speak of intonation, have been ignored in English education in Japan. There are two major problems discouraging Japanese teachers of English to enhance students' oral and aural abilities. One is that students do not have strong motivations to learn such skills since most entrance examinations of university or high school do not include these aspects but are limited to written English. The other is that a majority of Japanese teachers of English do not have confidence to teach those skills partly because they themselves lack sufficient oral/aural abilities and partly because they are not trained to teach those skills and do not know the teaching methodology (Watanabe 1994). As such, teaching intonation has consistently been neglected.

However, there are a few intonational items that Japanese teachers of English generally explain to students. In the beginning of 
ninth grade, that is the first time to learn English for most students, they are instructed to use a rising intonation at the end of a sentence of a yes/no question. Later, they are taught an intonation pattern for alternative questions. That is, a rising intonation should be used right before 'or' and a falling intonation, at the end of the sentence. But another variation of intonation for alternative questions, such as question (15), which is considered as a yes/no question, is not taught. When they first learn WH-questions, teachers explain to them that a falling intonation should be used at the end of an utterance for WHquestions. Only these three items are usually taught and emphasized in classroom without further instruction and consequently, students tend to overgeneralize these rules of thumb by the tenth grade. No follow-up instruction of intonation is conducted after that. Once they enroll in public high schools or most private high schools, they almost never learn intonation in classroom. Some high school teachers may explain the distinction between 'grèenhouse' and 'grèen hòse', the type of stress differences which determine intonation contour. Although some entrance examinations of college or university may deal with written questions regarding intonation, more often than not, students have to prepare for such questions by themselves with limited knowledge of intonation.

Apparently instruction of intonation in Japan is far from satisfactory. It is not even at the level of intonation examined in the present study. It is thus not surprising that Japanese students who have gone through this instruction have great difficulty in understanding English intonation. Their limited knowledge of 
intonation can even mislead them into misinterpreting a possibly ambiguous utterance, as can be seen in this study. Since they are forced to depend upon self-study of intonation, Japanese textbooks of English and dictionaries play an important role to provide information they need. It is therefore necessary to investigate such materials to see what information students can attain from them.

Descriptions of Intonation in Japanese Workbooks and Dictionaries

The above discussion indicates that Japanese textbooks of English includes few or no intonational issues because teachers rarely teach those matters. In fact, textbooks of English, especially, for high school students are considered as reading materials dealing with some grammatical structures and vocabulary. No issues of intonation are involved. As a consequence, instead of textbooks used in classroom, workbooks including supersegmental questions were examined.

One workbook for the ninth grade, Shinchugaku Mondaishu, provides the same type of descriptions for intonation as discussed in the previous section, namely, a rising intonation for yes/no questions, a rising and a falling intonation for alternative questions, and a falling intonation for WH-questions. These descriptions are very brief with one to two sentences and no written exercises are provided.

Another workbook for high school freshman or sophomore, Kokorîdo Mondaishu, includes a chapter called pronunciation and 
stress. With respect to supersegmental aspects, the following is described as key points:

1. Sentence pause --- Pause between groups of meaning (a) Pause before a verb when the subject is long (b) Pause before a conjunction, if any

2. Sentence stress --- Stress important words or words to be emphasized in the sentence. A noun, a demonstrative pronoun, an adjective, an adverb, a verb, and an interrogative pronoun are usually stressed (p. 171).

adopted and translated from Kokorîdo Mondaishu

Two sets of the exercises that ask students to figure out what word is most stressed is provided as below:

Where do you come from? --- I come from Tokyo. $\begin{array}{llll}1 & 2 & 3 & 4\end{array}$

The description above is accurate, but without aural materials and the associated instruction, students probably do not gain a clear understanding and will tend to overgeneralize rules arbitrarily. Since these exercises are limited to written English, it is doubtful whether students can develop the ability to comprehend the intonational pattern, though they might have no difficulty in answering such questions in written form.

Unlike these workbooks, English-Japanese dictionaries are more broadly used by a variety of learners of English. Three different dictionaries were examined to see whether or not any grammar-intonation relationships are described. The investigated words are any, all, and or, which possess ambiguous interpretations depending upon intonation. Descriptions of these three words in each dictionary are as follows: 
$\underline{\text { any }}$

New Collegiate No description.

Progressive Use the strong form [éni] if its following noun is omitted.

e.g. "I want some butter. Do you have ány?"

Genius Use the strong form [éni] if its following noun is omitted.

e.g. "I need some butter. Is there ány (any butter) in the frig?"

$\underline{\text { all }}$

New Collegiate Partial negation if 'all' is used in a negative sentence. But, it can be complete negation when 'all' and 'not' are separate.

e.g. Not all men are wise.

e.g. Not all the people could solve the problem.

(It is better to use 'None of the people could solve...' because it can be interpreted that 'Not all the people could solve...', except for when stress or intonation makes the distinction in verbal English.)

Progressive No description.

Genius Partial negation.

e.g. All children do not like apples.

Complete negation.

e.g. He did not answer áll the questions.

In verbal English, 'no' or 'none' is used to avoid ambiguity.

$\underline{\text { or }}$

New Collegiate A rising tone before 'or' and a falling tone 'or' are used.

e.g. "Will you be there or not?" 
Progressive e.g. "Will you have 'tea or 'coffee?" (tea or coffee)

e.g. "Will you have 'tea or [ə] 'coffee?" (tea, coffee, or something else)

Genius

e.g. "Which do you like better, 'tea or 'coffee?" (a rising and a falling intonation and the strong form [o:r])

e.g. "Do you drink 'whiskey or 'brandy?"

(a rising intonation and the week form [ər])

translated by Okubo

As can be seen from these examples, some dictionaries include issues related to intonation. However, none of the dictionaries provided adequate and precise information. As far as these three words (any, all, or) are concerned, a dictionary like the Genius Japanese-English Dictionary contains reasonably adequate information of grammar-phonology relationships.

The important point here is that there are not many materials to provide students knowledge of intonation. Textbooks, workbooks, or even some dictionaries do not fully explain how intonation affects syntactic structures. Some of the descriptions are misleading and confuse learners. Though intonation cannot be learned in the same way as grammar, students need, at least, explanations of intonation usage and more materials from which they can learn.

\section{The Importance of Comprehensible Input}

It is now evident that the area of teaching intonation in Japan needs enormous efforts to develop its methodology by improving existing teaching methods and materials as discussed above. The 
conclusion from the findings of the present study is that Japanese students lack of knowledge of intonation. Intonation is an aural/oral skill, which heavily depends upon language exposure. Since the Japanese students do not receive enough input to develop their linguistic competence, their poor performance was not surprising.

What Japanese students need first of all is comprehensible input as defined by Krashen (1981). An essential "condition for language acquisition to occur is that the acquirer understand (via hearing or reading) input language that contains structure 'a bit beyond' his or her current level of competence" (Krashen, 1981: 100). This is exactly what Japanese learners of English require. They need to build up competence through comprehensible input. Another important part of Krahsen's Input Hypothesis is to supply appropriate quality and quantity of grammar to the learners. This helps them to review what they have learned automatically. This approach can be applied to intonation as well as grammar. As to question pair (4-24) 'she dressed and fed the baby', in Japanese, different particles are used to distinguish 'dress' as a transitive or intransitive verb as follows:

'kanojowa akanboni fukuokisete monoo tabesaseta' (she dressed the baby and fed the baby) and

'kanojowa fukuokite akanboni monoo tabesaseta' (she dressed herself and fed the baby). In English this distinction would be effected using intonation. 
With respect to question pair (13-33) 'she won't drink any coffee', different syntax and vocabulary are used in Japanese to indicate complete or partial negation.

'kanojowa kohio mattaku nomanai'

(she drinks no coffee at all)

and

'kanojowa kohio nomuga tokubetsunataipunomoshika nomanai' (she drinks coffee, but only special types).

In English, however, different intonation patterns can be used to make this distinction.

It is believed that if an instructor points out these differences and gives appropriate explanations to students, they may improve their skills of intonation and even progress faster. Similar to grammar, providing some rules of thumb might help solve their problems in intonation. Without input, no output will develop. Comprehensible input of intonation therefore may be the key to becoming successful speakers of English.

\section{SUMMARY}

Based on the results of the present study, the causes of Japanese students' difficulty in comprehending English intonation are examined. The variances of the American group in this study evidence the complexity of intonational systems. Intonation is sometimes arbitrary in each language and even for native speakers, the interpretation of what is meant heavily dependent upon 
individual judgments. Not surprisingly, understanding the subtle differences that intonation creates is extremely difficult for nonnative speakers like Japanese students.

The errors that the Japanese students made are more systematic than random. The reason that they have considerable difficulty with categorization and paraphrase and little difficulty with attitudinal judgment might stem from their lack of knowledge of intonation-grammar relationships, regardless of their ability to recognize intonation patterns. Specifically, nine out of ten question pairs listed in the weakness section include intonation patterns that affect grammatical functions. An important point here, however, is that their difficulty appears to result from insufficient knowledge of how intonation affects syntactic structures rather than that of grammar per se. Since attitudinal type of intonation does not require such knowledge, they were able to master it within their knowledge of L2 and possibly L1.

In order to determine causes of their difficulty in understanding English intonation, it is necessary to investigate how English education in Japan deals with intonation. Since all the Japanese students had gone through this instruction, their lack of knowledge of intonation must result from insufficient intonation methodology. What is needed is comprehensible input of intonation in order to develop this linguistic competence. 


\section{CHAPTER VI}

\section{CONCLUSIONS}

Limitations of the present study and suggestions for further research are discussed in this chapter. Based on the findings of the study, pedagogical implications are considered.

\section{RESEARCH IMPLICATIONS}

\section{Conclusions}

The goals of this study were to find out to what extent Japanese adult learners can comprehend intonation in English and to probe what features, if any, cause their difficulty,. The conclusion from this investigation must be that Japanese students' intonational comprehension is unsatisfactory and their difficulty stem from the grammatical functions of intonation, most of which are local to English. This aspect of intonation can be extremely difficult for not only Japanese students, but also for non-native speakers in general to understand without any help. Similar to grammar, providing explicit rules may help them alleviate their difficulty. In Japan, unfortunately, the absence of materials to learn such rules for intonation results in their lack of intonational competence.

An attitudinal function of intonation, on the other hand, is fairly easy for them to understand. Intonation universals described 
by such researchers as Cruttenden (1981) and Bolinger (1978) might be able to explain this fact. If there is a universal tendency of intonation regarding its attitudinal function, the Japanese students could take advantage of their L1 knowledge to judge what the intonation of an utterance means, that is, L1 transfer. Since most of them had never been taught such an aspect of intonation, all they could rely on was their limited L2 knowledge and L1 knowledge of intonation. It is also possible that they have acquired the attitudinal function of intonation as they are more exposed to L2. Even so, L1 transfer cannot be discounted because a number of similarities concerning the attitudinal function are observed in both Japanese and English.

However, it is unclear as to what extent L1 transfer (positive and negative) and a lack of L2 knowledge affect intonational comprehension. As Cruttenden (1981) explains, the distinction in lexical, grammatical, discorsal and attitudinal in intonation per se is usually quite vague, and its judgment is dependent much on a speaker's point of view. This vagueness also makes it impossible to point out exactly under what circumstance learners employ L1 knowledge, L2 knowledge, or both.

The discussion here is limited to a perceptual level of intonation, not production. On the basis of the conclusions of this study, what can be speculated with respect to production of intonation is that Japanese students are probably unable to manipulate the distinction of intonational variations that they had difficulty with in the study. In a real conversation, contexts 
including a number of linguistic variables can help them to understand what a speaker actually means or to converse with native speakers without great difficulty. What is more, asking confirmation from a speaker is a natural conversational strategy to avoid misunderstanding. Yet, especially advanced learners who have mastered other aspects of linguistic competence, may create a false expectation of intonational competence which can lead to misunderstanding when interacting with native speakers.

In order to support these speculations, more research is needed in this field. Before considering suggestions for further research, it is necessary to discuss what kind of limits are imposed by the methodology selected for this research project.

\section{Limitations of the Study}

Several issues on the methodology need be concerned. First, in this study, multiple choice was used to measure the subjects' listening comprehension of intonation. As mentioned in Chapter III, due to the disadvantages of multiple choice type of questions, the results of the study did not necessarily reflect accurate intonational abilities of the subjects. In order to avoid their intelligent guess, contrastive variation pairs were devised. However, this pair setting prompted another problem. Some of the subjects chose the same interpretation for both variations to ensure that was answered correctly. This indicates that they might have actually understood neither of the variations, even if they answered one correctly. Conversely, there were some subjects who seemed to truly 
understand one variation and chose an incorrect answer for the other variation. But, there was no way to differentiate these two groups in this research method. As a consequence, the methodology was not successful in identifying answers which were based on guess.

The second limitation concerns the number of questions examined. The total amount of questions were twenty question pairs (forty sentences). However, since the performance of the control group was more varied than had been expected, it was necessary to establish the $70 \%$ or $80 \%$ validity thresholds to analyze the performances of Japanese students. This reduced the number of questions to be closely analyzed because there was no point in evaluating their performance on questions on which the control group performed poorly. Hence, the final number of questions examined was fourteen pairs, which is not sufficient to determine precisely whether their errors are systematically made. More questions should be provided so as to attain more accurate results.

Third, a lack of concept familiarity might have affected the choice of responses of Japanese students. Specifically, a concept such as 'dog biscuits' in question pair (16-36), might have been unfamiliar to them. Therefore, it is possible that some other variables, like this, may have influenced this study.

Finally, there was no clear delimitation as to whether difficulty of the Japanese students resulted from either a phonological aspect of intonation or a grammatical one. More specifically, their answers did not explain whether they were unable to hear the difference between two variations of intonation or whether they were able to 
make the distinction, but unable to assign each variation to its correct response because of grammatical difficulty. This study therefore could not ascertain specific phonological features of intonation that the Japanese students were unable to comprehend.

\section{Suggestions for Further Research}

In order to find stronger evidence of the findings reported in this study, further research is needed. Other aspects of intonation that this study did not investigate may be able to support the speculations postulated here. Four specific suggestions for further research are provided as follows:

1. Dividing the intonational comprehension task into two subtasks: discrimination and interpretation. Since it was difficult to judge on whether the difficulty of Japanese students stem from the issue of phonology or grammar, it is useful to have two separate tasks. The first task is that students listen to two sets of an utterance with a different or the same intonational pattern from an audio tape once and respond if both of the utterances are identifiable or not. For second task, they listen to these two utterances twice to assign each of them to its correct interpretation. Conducting these two phases can distinguish a problem of listening comprehension from that of grammar.

2. In order to assess the extent to which subjects might be guessing correct responses, one or both of the question pair variations should be repeated in the test instrument. Failure to 
answer the same question variations consistently would be suggest that the subject in guessing.

3. Although this study only focused on the perception of intonation, its production should be investigated. Examining the correlation between their perception and production can make it possible to measure more accurately subjects' abilities of intonation. This can be achieved by having the process of production follows that of perception. For example, subjects are given two different interpretations of the same sentence and asked to read aloud its two variations according to the interpretation. Their utterances are tape recorded and judged by native speakers of English what the utterance means. Then, the subjects would take a comprehension task such as in the present study. These two steps may be able to determine whether or not the subjects have knowledge of intonation and where their difficulty arises, either a lack of such knowledge or comprehension.

4. Learners of English who speak some other languages should be examined so as to determine if the error patterns of intonation differ across native language groups. In this study, only native speakers of Japanese were investigated and the findings indicated that they had no difficulty with an attitudinal type of intonation, but they did have difficulty with paraphrase and categorization. Particularly, certain types of sentences that require grammatical knowledge as well as intonational were found to be most problematic for the Japanese students. These error patterns might be characteristics of Japanese students or non-native speakers in general, regardless of what native 
language they speak. In order to probe this issue, a variety of native language speakers of English should be examined, which might be able to determine if intonation universals indeed exist.

\section{PEDAGOGICAL IMPLICATIONS}

\section{Need for Comprehensible Input}

One of the speculations from the findings of this study is that the Japanese students lack knowledge of intonation. This fact is rather predictable for researchers who have a teaching or learning experience of English in Japan, such as Watanabe (1994) and myself. Watanabe (1994) asserts that he is not aware of intonation or rhythm being intentionally taught in Japanese classrooms. Since intonation requires aural ability of the target language, this lack of intonational input must adversely impact Japanese students' intonational comprehension. In addition to that, grammar translation methods practiced in Japanese classes of English, as discussed in Chapter II, do not give any advantage for learning intonation. Japanese students are seldom given opportunities to enhance their aural skills. Obviously, what they need is to have adequate comprehensible input of intonation and to be exposed to English aurally.

Intonation can be considered the melody of language (see Chapter II), which implies that listening must be primary in learning intonation. Supersegmental aspects of phonology are often compared to music. Pitches that play a role of musical notes, rhythm, and 
pause are involved. Similar to music, one can have a much better idea of what intonation patterns sound like via listening rather than written materials.

At the next step, appropriate quality and quantity of explanations for intonation should be supplied to the Japanese learners, according to their ESL levels. As discussed before, learning intonation is similar to learning grammar in the sense that students have to acknowledge certain rules, such as under what circumstance and how a particular item is used and how it affects a syntacitc structure. Intonation, however, can be sometimes arbitrary so that more exceptions are observed than for grammatical items. In order to avoid the Japanese students' confusion, typical intonation patterns that a majority of native speakers agree with should be presented. As a follow-up instruction, making them aware of some other variations and associated demonstrations of the instructor are needed. If an instructor is a nonnative speaker of English, an audiotape is a great aid. In this case, the instructor should examine intonation patterns on the tape in advance and be prepared to demonstrate the intonation that he/she focuses on in class. This might help them not only to stay alert to different variations they may encounter, but also to pay attention to subtleties of intonation.

More specifically, grammar-intonation relationship should be well explained to the Japanese students. As the findings of this study indicates their confusion of intonation related to grammar, they need to understand how intonation affects the meaning of a sentence in a grammatical sense. This aspect is often not general, but 
local to English, thus, without explaining such grammar-intonation relationships to them, they would probably not notice such subtleties.

In sum, what Japanese students need most is comprehensible input for learning intonation. Due to the absence of aural training of English in Japan, they have enormous difficulty with intonation as well as listening comprehension as a whole. In order to compensate for this drawback, it is essential to give them adequate opportunities to develop linguistic competence of intonation.

\section{Conscious Attention to Supersegmentals}

As well as the importance of comprehensible input, Japanese students need to be aware of differences of supersegmentals between English and Japanese. Since rhythm and stress determine intonation patterns (see Chapter II), it is necessary to teach overall supersegmental aspects to them. Especially, if there are aspects of English which do not exist in Japanese, explaining such differences helps them to understand the concept of English supersegmentals and to pay more attention to the differences in the target language. For example, an obvious difference between the two languages is that English is a stress-timed rhythm while Japanese is a syllabletimed rhythm. As Watanabe (1994) explains, native English speakers judge stress by means of pitch height, duration, and loudness whereas native Japanese speakers make judgments by means of pitch height only since the duration between each syllable and loudness, normally, is approximately same in Japanese. 
Consequently, when Japanese students listen to English they are confused by pitch height and misunderstand, or when they speak English, it is often unclear where stress is and where it is not. More often than not, they are unaware of this rhythmic difference, so they apply the same rhythm to English, which makes their utterances sound unnatural to native speakers. More specifically, a phrase, such as 'pick it up' is stressed on each word and pronounced like each separate word, 'pick', 'it,' 'up'. This type of difference between the two languages requires adult learners conscious efforts to master. Pointing out such differences helps them to learn this aspect more quickly. Teachers who are native speakers of English should bear in mind that characteristics of Japanese speakers of English and spend more time on English supersegmental aspects that are missing or different in Japanese. Acknowledging such characteristics makes it possible for teachers to develop the most effective teaching method for them.

Although focusing on a particular issue to overcome such weaknesses is useful, when it comes to teaching intonation, teachers need to integrate all aspects of supersegmentals. The fact that intonation encompasses rhythm and stress makes it more difficult for Japanese students to learn it. In order to avoid overwhelming them, teachers should first introduce how different English rhythm and stress are from those of Japanese. At the next step, intonation must be introduced. This can reduce their confusion for complexity of intonation and make students focus on intonation rather consider all three aspects of supersegmentals simultaneously. 


\section{$\underline{\text { Self-correct and Self-monitor }}$}

What Japanese students lack is knowledge of intonation and enough attention to it in perception and most likely production. This fact indicates that they do not have the ability to either self-correct or self-monitor intonation. Firth (1992) defines that "self-correction is the ability to correct oneself when a pronunciation error has been pointed out .... and self-monitoring, on the other hand, is the ability to listen for and recognize errors" (p. 215). This is the final goal of intonation as well as pronunciation as a whole for language learners. Due to the insufficient ability of Japanese students to comprehend intonation, instructors need to help them develop such self skills.

These skills play an important role of language learning. In most cases, available time for instruction is limited. It therefore depends much upon students' practice outside of class as to whether or not they improve their abilities of intonation. For self-correction, an instructor's feedback is crucial. If a student is using an inappropriate stress or intonation, the instructor should repeat the incorrect form to make him/her aware of it, and if necessary, exaggerate it, (Firth,1992). For self-monitoring, an instructor can demonstrate the contrast between an appropriate intonation pattern and an inappropriate pattern. Audio-tapes can also help them to self-monitor, if an instructor explains to them what they need to focus on specifically. By these techniques, students will be able to recognize the distinction. 
Once they gain both self-correction and self-monitoring, they can take advantage of opportunities as they encounter them. Movies, $\mathrm{TV}$, or actual conversations by native speakers can be good material for learning intonation. Reaching this point is probably a long road for Japanese students because they need great deal of comprehensible input, but this goal can be attained with appropriate instruction. Finally, developing teaching methodologies considering differences between L1 and L2 leads learners to achieving comprehensibility of supersegmentals. 


\section{REFERENCES}

Abe, I. (1955). Intonational patterns of English and Japanese. Word II, 386-398.

Beckman, M. E. (1986). Stress and non-stress accent. Dordrecht, Holland: Foris Publications.

Beckman, M. E. \& Pierrehumbert, J. B. (1986). Intonational Structure in Japanese and English. Phonology Yearbook, 3, 255-310.

Bloch, B. (1950). Studies in colloquial Japanese IV: Phonemics. Language 26, 86-125.

Bohlken, R., \& Macias, L. (1992). What a nonnative speaker of English needs to learn through listening. Paper presented at the Annual Meeting of the International Listening Association, Seattle.

Bolinger, D. (1989). Intonation and Its Uses. Stanford: Stanford University Press.

Bolinger, D. (1951). Intonation -- levels vs. configurations. Word, 7, 199-210.

Borden, G., Gerber, A., \& Milsark, G. (1983). Production and perception of the /r/-/1/ contrast in Korean adults learning English. Language Learning, 33 (4), 499-526.

Cruttenden, A. (1981). Falls and rises: meanings and universals. Journal of Linguistics, 17, 77-91.

Cruttenden, A. (1986). Intonation. Washington D.C.: Washington Publications. 
Cruz-Ferreira, M. (1987). Non-native Interpretive Strategies for intonational Meaning: An Experimental Study. In A. James \& J. Leather (Eds.), Sound Patterns in Second Language Acquisition. Dordrecht, Holland: Foris.

Crystal, D. (1969). Prosodic Systems and Intonation in English. London: Cambridge University Press.

Firth, S. (1992). Developing self-correcting and self-monitoring strategies. In P. Avery and S. Ehrlich(Eds.), Teaching American English Pornunciation.

Fries, C. C. (1945). Teaching and Learning English as a Foreign Language. Ann Arbor: University of Michigan Press.

Gilbert, J. B. (1984). Clear speech: Pronunciation and listening Comprehension in American English. New York: Cambridge University Press.

Gleason, H. A., Jr. (1965). An introduction to descriptive linguistics. New York: Holt, Rinehart \& Winston.

Graham, C. (1992). Singing, Chanting, Telling Tales. New Jersey: Prentice-Hall, Inc.

Graham, C. (1978). Jazz Chants. New York: Oxford University Press.

Hogen, S. A., \& Grogan, P. E. (1992). Sound advantage: a pronunciation book. New Jersey: Prentice Hall Regents.

Homma, T. (1994, Feb.). Henkakusuru Nihon no Eigo Kyoiku (Changing English Education in Japan). International Education Currents. pp. 1-5.

Kenworthy, J. (1987). Teaching English pronunciation. New York: Longman. 
Kitao, K. S., Kitao, K., Nozawa, K., \& Yamamoto, K. (1985). Teaching English in Japan. (Publication No. ED265 741). Washington DC: Office of Educational Research and Improvement.

Krashen, S. D. (1981) Second language acquisition and second language learning. Oxford: Pergamon Press.

Krashen, S. D. (1985) Language acquision theory and materials development. In Joan Wolfgang (Ed.), Inquires \& isights (pp. 723). Heyward Almay Press.

Ladd, D. R., Jr. (1977). The function of the A-rise accent in English. Bloomington: Indiana University Linguistics Club.

Lea, W. A. (1977). Acoustic correlates of stress and juncture. In L. Hyman (Ed.), Studies in stress and accent (Southern California Occasional Papers in Linguistics, 4: 83-120).

Liberman, P. (1967). Intonation, perception, and language. Cambridge: M. I. T. Press.

Liberman, M. (1978). The intonational system of English. Bloomington: Indiana University Linguistics Club.

Liberman, M., \& Sag, I. (1974). Prosodic form and discourse function. PCLS, 10: 416-427.

Lepetit, D. (1989). Cross-linguistic Influence in Intonation:

French/Japanese and French/English. Language Learning, 39 (3): $\quad 397-413$.

Luthy, M. J. (1983). Nonnative speakers' perceptions of English: "nonlexical" intonation signals. Language Learning, 33 (1): 1937.

Morley, J. (1991). The pronunciation component in teaching English to Speakers of Other Languages. TESOL Quarterly, 25 (3):481519. 
Murphy, J. M. (1991). Oral Communication in TESOL: Integrating Speaking, Listening, and Pronunciation. TESOL Quarterly, 25 (1): $51-75$.

Okumura, E. (1979). An analysis of the intonation patterns of Japanese learners of American English and suggestions for the teaching of the patterns. Unpublished master's thesis, Portland State University.

O'Cornnor, J. D. (1967). Better English Pronunciation. London: Cambridge University Press.

O'Malley, J. J., \& Chamot, A. (1989). Learning strategies in second language acquisition. New York: Cambridge University Press.

Oxford, R. (1990). Language learning strategies. New York: Newbury House.

Pike, K. L. (1945). The Intonation of American English. Ann Arbor: University of Michigan Press.

Sheeler, W. D., \& Markley, R. W. (1991). Sounds and Rhythm: A Pronunciation Course. New jersey: Prentice-Hall, Inc.

Tannen, D. (1986). That's not what I meant!: how conversational style makes or breaks relationships. New York: Ballantine books.

Teaman, B. D. (1992). Stress on Japanese English: Evidence from native perceptual judgments. Working Papers in Educational Linguistics, $\quad 8,(1) .: 69-83$. Pennsylvania: Department of Linguistics, University of Pennsylvania.

Trinandis, H. C. (1994). Culture and socialbBehavior. New York: McCraw-Hill, Inc.

Uldall, E. T. (1960). Attitudinal meanings conveyed by intonation. Language and Speech, 3: 223-34. 
Wardhaugh, R. (1992). An Intorduction to sociolinguistics: Second edition. Cambridge: Blackwell Publishers.

Watanabe, K. (1988). Sentence stress Perception by Japanese studnents. Journal of Phonetics, 16: 181-6.

Watanabe, K. (1994). Eigo no rizumu, intoneshon no shido (Instuction for English Rythm and Intonation). Tokyo: Taishukan Shoten.

Zimmermann, G. N., Price, P. J., \& Ayusawa, T. (1984). The production of English / $/ \mathrm{r}$ and /l/ by two Japanese speakers of differing in experience with English. Journal of Phonetics, 12: $187-193$. 
APPENDIX A

COMPREHENSION TEST OF INTONATION IN ENGLISH 


\section{Pretest}

1. she speaks `English/ naturally
a. she speaks English in a natural way
b. it is natural that she speaks English because she's English
c. it is natural that she speaks English, although she's not English

2. Mary's gone shopping
a. the speaker is asking why Mary has gone shopping
b. the speaker is asking whether Mary has gone shopping
c. the speaker is stating that Mary has gone shopping

3. they don't admit `any students
a. they admit no students at all
b. they prefer to admit teachers
c. they admit some students only

4. I only grow vegetables
a. I don't eat the vegetables, I just grow them
b. I ' $m$ the only person who grows vegetables
c. I grow nothing else but vegetables

\section{Main test}

1. they've bought a new car
a. the speaker is saying that they've bought a new car
b. the speaker is asking what type of car they've bought
c. the speaker is asking whether they've bought a new car

2. I know Bill's son John/ and 'Harry
a. I know Bill, I know John, and I know Harry
b. I know John, who is Bill's son, and I know Harry
c. I know Bill's son, I know John, and I know Harry

3. he also translated the book
a. he was one of the people who translated the book
b. he not only translated the magazines but also the book 
c. he not only wrote the book but also translated it

4. she dressed/ and fed the 'baby
a. she dressed the baby for feeding
b. she dressed the baby and fed the baby
c. she dressed herself and fed the baby

5. I know 'that sheep can swim
a. I know that all sheep can swim
b. I know one particular sheep that can swim
c. I know that some sheep can swim

6. didn't John en 'joy it
a. the speaker is asking if John enjoyed it
b. the speaker is saying that John did not enjoy it
c. the speaker is remarking on how great John's enjoyment was

7. she didn't get `one present at Christmas
a. she got no presents at all at Christmas
b. she got one present after Christmas
c. she got more than one present at Christmas

8. he can't see `clealy
a. it is clear that he can't see at all
b. he can see, but not very clearly
c. the day is so clear that he can't see anything

9. I thought she was `married
a. I thought about her marriage
b. I thought she was married, but she isn't
c. I thought she was married, and so she is

10. I didn't go out because I wanted to `see you
a. I stayed home, but not because I wanted to see you
b. I stayed home, but I couldn't see you 
c. I stayed home because I wanted to see you

11. what are you doing here
a. the speaker is asking a question in a neutral way
b. the speaker is asking a question in a rude way
c. the speaker is asking a question in a polite way

12. I think he's `comptent
a. I have no doubts about his competence or about him at all
b. I have no doubts about his competence, but I doubt his motivations
c. I don't think he's very competent

13. she won't drink `any coffee
a. she drinks no coffee at all
b. she prefers tea to coffee
c. she drinks coffee, but only special types

14. they've 'left / the children
a. the children have left someone
b. the children have left
c. someone has left the children

15. would you like tea/ or coffee
a. the speaker is offering tea, or coffee, or something else
b. the speaker is offering either tea or coffee only
c. the speaker wants to offer coffee instead of tea

16. she gave her `dog biscuits
a. she gave biscuits to her dog
b. she gave dog biscuits to somebody
c. she gave dog biscuits to her dog

17. he might have told me
a. he should have told me, but he didn't
b. it is possible that he has told me, but I forgot 
c. he should have told me, and so he has

18. the children who were playing looked unhappy

a. the children were playing because they looked unhappy

b. some children were playing and only they looked unhappy

c. all the children were playing and all looked unhappy

19. John passed his êxams

a. the speaker is stating in a neutral way that John passed his exams

b. the speaker is asking if John passed his exams

c. the speaker is surprised because John passed his exams

20. John hit Sam and then 'he kicked 'him

a. John hit Sam and then someone else kicked Sam

b. John hit Sam and then John kicked Sam

c. John hit Sam and then Sam kicked John

21. they've bought a'new car

a. the speaker is saying that they've bought a new car

b. the speaker is asking what type of car they've bought

c. the speaker is asking whether they've bought a new car

22. I know Bill's s, son / John/ and'Harry

a. I know Bill, I know John, and I know Harry

b. I know John, who is Bill's son, and I know Harry

c. I know Bill's son, I know John, and I know Harry

23. he also translated the book

a. he was one of the people who translated the book

b. he not only translated the magazines but also the book

c. he not only wrote the book but also translated it

24. she dressed and fed the 'baby

a. she dressed the baby for feeding

b. she dressed the baby and fed the baby 
c. she dressed herself and fed the baby

25. I know that sheep can`swim

a. I know that all sheep can swim

b. I know one particular sheep that can swim

c. I know that some sheep can swim

26. didn't John enjoy it
a. the speaker is asking if John enjoyed it
b. the speaker is saying that John did not enjoy it
c. the speaker is remarking on how great John's enjoyment was

27. she didn't get òne present at Christmas
a. she got no presents at all at Christmas
b. she got one present after Christmas
c. she got more than one present at Christmas

28. he can't `see/ clealy
a. it is clear that he can't see at all
b. he can see, but not very clearly
c. the day is so clear that he can't see anything

29. I thought she was married
a. I thought about her marriage
b. I thought she was married, but she isn't
c. I thought she was married, and so she is

30. I didn't go `out /because I wanted to`see you
a. I stayed home, but not because I wanted to see you
b. I stayed home, but I couldn't see you
c. I stayed home, because I wanted to see you

31. what are you'doing here
a. the speaker is asking a question in a neutral way
b. the speaker is asking a question in a rude way 
c. the speaker is asking a question in a polite way

32. I think he's'comptent

a. I have no doubts about his competence or about him at all

b. I have no doubts about his competence, but I doubt his motivations

c. I don't think he's very competent

33. she won't drink' any coffee
a. she drinks no coffee at all
b. she prefers tea to coffee
c. she drinks coffee, but only special coffee

34. they've left the 'children
a. the children have left someone
b. the children have left
c. someone has left the children

35. would you like tea/ or coffee
a. the speaker is offering tea, or coffee, or something else
b. the speaker is offering either tea or coffee only
c. the speaker wants to offer coffee instead of tea

36. she gave her dog ' biscuits
a. she gave biscuits to her dog
b. she gave dog biscuits to somebody
c. she gave dog biscuits to her dog

37. he `might have told me
a. he should have told me, but he didn't
b. it is possible that he has told me, but I forgot
c. he should have told me, and so he has

38. the children/ who were playing/ looked unhappy
a. the children were playing because they looked unhappy
b. some children were playing and only they looked unhappy 
c. all the children were playing and all looked unhappy

39. John passed his èxams

a. the speaker is stating in a neutral way that John passed his exams

b. the speaker is asking if John passed his exams

c. the speaker is surprised because John passed his exams

40. John hit Sam and then he `kicked him

a. John hit Sam and then someone else kicked Sam

b. John hit Sam and then John kicked Sam

c. John hit Sam and then Sam kicked John 
APPENDIX B

RESPONSES TO COMPREHENSION TEST IN JAPANESE 


\section{プリテスト}

1。a，彼女は英語を目然に話す。

b、彼好が英語を話すのは当然だ。というのもイギリス人だからだ。

c、彼女が英語を話すのは当然だ。イギリス人ではなけれども。

2.a、話者はメアリ一がなぜ買い物へ行ったか噚ねている。

り．話者はメアリ一が買い物へ行ったかどうか艮机ている。

こ．話者はメアリーが質い物へ行ったと述べている。

3、a、彼らはどの生徒も入れない。

b．彼らは先尘を入记る斿を㕵んでいる。

c，彼らは何人かの生徒だけを入れる。

4.a．その野菜は食へないが育垊。

b．野菜有てているのは私だけだ。

c．野菜たけしか充てていない。

\section{イインテスト}

1、a、話者は彼らが新しい車を買ったと言っている。

b．話者は彼らがどんなイプの車を買ったか尋ねている。

c．話者は彼らが新しい車を買ったかどうか閔数ている。

2、a.ビルも知っているし、ジョンも知っているし、ハリーも知っている。

b．ビルの息子であるションも知ってるし、ハリ一も知っている。

c.ビルの息子も知っているし、ジョンも膓っているし、ハリーも知っている。

3。a，彼はその本を訳したうちの一人だ。

b、彼はその赫誌だけでなく、その本も訳した。

C、波はをの本を望いただけでなく、䑩訳もした。

4. a . 彼女は赤ん场に物を食へさせるために服を着せた。

b、彼文は赤九域に服を着せて物を食へさせた。

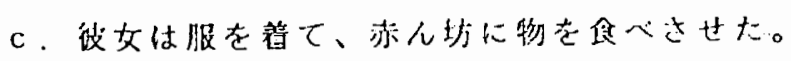




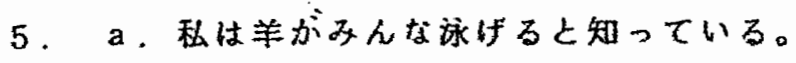

b、私は泳代る一融の羊知っている。

c、私は泳げる羊が何頭かいるのを知っている。

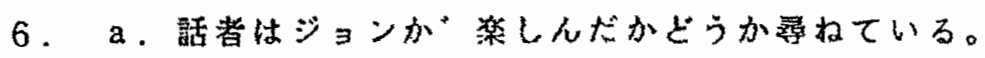

๖、話者はショョンが桨しまなかったことを言っている。

c、話者はショョンがどれだけ楽しんだか述べている。

7.a、彼妓タリスマスに一つもブレゼントをもらわなかった。

b、被女はクリスマスの锊にひとつプレゼントをbらった。

c、彼女はクリスマスにひとつ以上プレゼントをもらった。

8.a，彼が目が見えないのは明らかだ。

b、彼は目が見元るが、あまりハッキリ見えない。

c。、天気が良すきて彼は何も見元ない。

9、a、彼女の結婚について考元た。

b、彼女は結㛭していると思ったがしていない。

c、彼女は結婚していると思ったが、そのとおりだ。

10、a、私は家にいたが、あなたに会いたかったからではない。

๖、私は家にいたが、あなたに会えなかった。

c、私は家にいた。というのもおなたに会いたかったからだ。

11、a，話者は普通の言い万で貿問を專好ている。

b：話者仗礼な言い方で質問を專ねている。

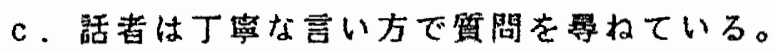

12.a．彼の能力にも被のすべてにも疑いはない。

b、彼の能力には疑いはないが彼の動機が疑わしい。

c、彼にはあまり能力がある之思わない。

13．ａ，彼女はコ一七一を全く飲まない。

b、彼好はコーヒーより挍を好む。

c. 彼女はコーヒ一を饮むが特别なタイプのものしか飭まない。 
14.a。をの子供たちは誰かを残していった。

b，その子供たちは让ち去った。

c、誰かがその子供たちを残していった。

15．a．話者はお茶かコーヒ一、又は他の何かを钦めている。

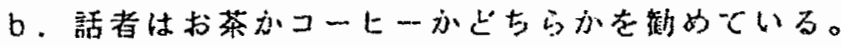

c、話者はお茶の代わりにコーヒ一を锄めたがっている。

1.6.a.佊女はビスケットを自分の犬にやった。

b，彼女は大のビスケットを誰かにあげた。

c．彼女は犬のビスケットを自分の犬にやった。

17.a.彼は私に話すべきだったのにしなかった。

b、彼は私に話したかもしれないが私は忘れた。

c、彼は私に話すへきだったし、そうした。

18 ．a．子供たちは悲しそうなので遊んでいた。

b．何人かの子供たちが遊んでいて、その子供たちだけが悲しそうだった。

c．于供たちはみんな遊んでいて、みんな悲しそうだった。

19、a、話者はジョンが武験に合格したことを単に述べている。

b. 話者はショョンが武験に合格したかとうか器机ている。

c、話者沬ジョンが武験に合格したので筑いている。

20 、a、ジョンはサムを股り、誰加他の人がサムを䟽った。

b、ジョンはサムを股り、そして践った。

c.ジョンはサムを没り、サムはジョンを踣った。

21、a、話者は彼らが新しい車を買ったと言っている。

b、話者は彼らがどんなタプの車是ったか器好ている。

c、話者は彼らが新しい東を買ったかとうか器标ている。

22. a.ビルも知っているし、ションも知っているし、ハリ一も知っている。

b、ビルの息子であるションも知ってるし、ハリーも知っている。

c、ビルの息子も知っているし、ションも知っているし、⿳リーも知っている。 
2 3.a.彼はその本を訳したうちの一人だ。

b、彼はその雑誌だけでなく、その本も訳した。

c、彼はその本を書いただけでなく、翻訳もした。

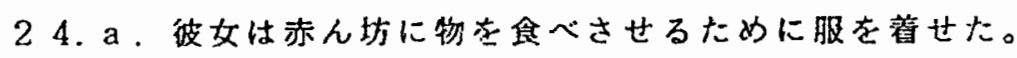

b、彼女は赤ん坊に服を着せて物を飱べさせた。

c、彼女は服を着て、赤ん施に物を食べさせた。

25 . a。私は羊がみんな泳げると知っている。

b. 私は泳げる一頙の羊を知っている。

c、私は泳げる羊が何预かいるのを知っている。

2 6.a.話者はションが楽しんたかどうか門ねている。

b 、話者はジョンが楽しまなかつたことを言っている。

c、話者はジョンがどれだけ楽しんだか述へている。

27. a. 铍女はクリスマスに一つもブレゼントをもらわなかった。

b.彼女はクリスマスの後にひとつブレゼントをもらつた。

c。彼女はクリスマスにひとつ以上プレゼントをもらった。

28 . a. 彼が目が見えないのは明らかだ。

b、彼は目が見えるが、あまりハッキリ見えない。

c、天気が良すぎて彼は何も見えない。

29. a. 彼女の結婚について考えた。

b．彼女は結媘していると思つたがしていない。

c．彼女咭婚していると思ったが、そのとおりだ。

3 0.a．私は家にいたが、あなたに会いたかったからではない。

り、私は家にいたが、あなたに全えなかった。

c、私は家にいた。というのもあなたに会いたかったからだ。

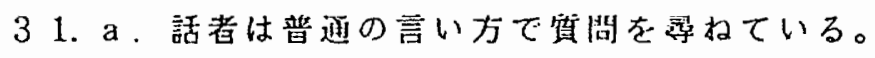

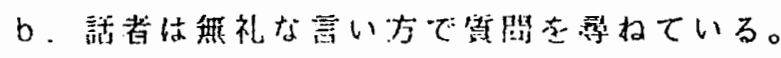

c、話者は丁盤な言い方で筫問走㓪好ている。 
32 . a 彼の能力にも彼のすべてにも疑いはない。

b、彼の能力には寲いははいが彼の動機が疑わしい。

c、彼にはあまり能力があると思わない。

33．a，彼女はコーヒ一を全く饮まない。

b。彼女はコ一七一よりお茶を好む。

c. 彼女はコーヒ一を飲むが特別なタイプのものしか飲まない。

34 、a．その子供たちは誰かを残していった。

b，その子供たちは立ち去った。

c、誰かがその子供たちを残していった。

35 、a。話者はお茶かコーヒ一、又は他の何かを锄めている。

b. 話者はお茶かコーヒ一かどちらかを初めている。

c、話者はお茶の代わりにコ一ヒーを锄めたがっている。

36．a．彼女はビスケットを自分の犬にやった。

b、彼女は大のビスケットを誰かにあげた。

c。彼女は犬のビスケットを自分の犬にやった。

37．a．彼は私に話すべきだったのにしなかった。

b、彼は私に話したかもしれないが私は忘れた。

c、彼は私に話すべきだったし、そうした。

38．a．子供たちは悲しそうなので遊んでいた。

b、何人かの子供たちが進んでいて、その子供たちだけが悲しそうだった。

c．子供たちはみんな遊んでいて、みんな悲しそうだった。

39.a.話者はションが陚験に合格したことを単に述べている。

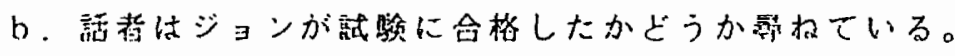

c、話者はショョンが陚験に合格したので第いている。

40、a、ジョンはサムを眨り、誰か他の人がサムを躈った。

b.ションはサムを没り、そして䟽った。

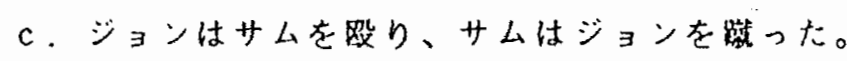


APPENDIX C

SURVEY SHEET 
1. Subject's number 3-5

2. Age $7-8$

3. Sex (Circle one) 1. Male 2. Female 10

4. Status in school (Circle one) 1. Undergraduate 2. Postbac
3. Graduate
4. Ph. D
5. ESL
6. Others
12

5. TOEFL Score (if any) ___ 14-16

6. Residence a. Country _ـ 18

b. How long have you lived there (in years) _ 20-21

7. Birthplace a. Country 23

b. How long have you lived there (in years) _ 25-26

8. Where are your parents / closest relatives from (country) _ 28

9. Number of years of study of English _ $\quad 30-31$

10. Any visit to the U.S.A or other English-speaking country
a. Country 33
b. How long (weeks) 35-36
c. Purpose of the visit 


\section{APPENDIX D}

LIST OF JAPANESE SUBJECTS 


\begin{tabular}{|c|c|c|c|c|c|c|c|c|c|c|}
\hline Subject & Age & $\begin{array}{l}\text { Male/ } \\
\text { Female }\end{array}$ & $\begin{array}{l}\text { Status in } \\
\text { School }\end{array}$ & TOER. & $\begin{array}{l}\text { Length of } \\
\text { Current } \\
\text { Residence }\end{array}$ & $\begin{array}{l}\text { Length of } \\
\text { Studying } \\
\text { English }\end{array}$ & $\begin{array}{c}\text { Other Stay in } \\
\text { Eng-speaking } \\
\text { Countries }\end{array}$ & $\begin{array}{l}\text { Length } \\
\text { of the } \\
\text { Stay }\end{array}$ & $\begin{array}{c}\text { Purpose of } \\
\text { the Visit }\end{array}$ & $\begin{array}{r}\text { Test Score } \\
140\end{array}$ \\
\hline 1 & 27 & $\mathrm{~F}$ & ESL & 497 & $1 y$ & $7 y$ & UK \& etc. & $1 \mathrm{~m}$ & travel & 28 \\
\hline 2 & 24 & $\mathrm{~F}$ & ESL & 446 & $6 \mathrm{~m}$ & $12 y$ & USA \& etc. & $3 w$ & travel & 22 \\
\hline 3 & 26 & $\mathrm{~F}$ & ESL & & $11 \mathrm{~m}$ & $7 v$ & USA & $1 y$ & study English & 23 \\
\hline 4 & 26 & $F$ & ESL & & $1 \mathrm{~m}$ & $13 v$ & Aus.\& etc. & $2 v$ & study English & 30 \\
\hline 5 & 18 & $F$ & ESL & 446 & $2 m$ & $6 y$ & Canada & $3 d$ & travel & 22 \\
\hline 6 & 30 & $\mathrm{~F}$ & PB & 620 & $3 y$ & $17 y$ & Canada & $3 w$ & travel & 22 \\
\hline 7 & 35 & $F$ & $L G$ & 535 & $4 y$ & $12 y$ & none & & & 27 \\
\hline 8 & 21 & $M$ & LG & 520 & $2 y \& 6 m$ & $9 y$ & Canada & $2 w$ & travel & 21 \\
\hline 9 & 20 & $F$ & LG & & $2 y$ & $8 y$ & none & & & 27 \\
\hline 10 & 31 & M & $U G$ & 580 & $8 y$ & $21 y$ & & & & 26 \\
\hline 11 & 22 & $\mathrm{~F}$ & UG & & $1 \mathrm{y} \& 8 \mathrm{~m}$ & $8 y$ & & & & 21 \\
\hline 12 & 21 & $\mathrm{~F}$ & ESL & & $4 \mathrm{~m}$ & $11 y$ & none & & & 26 \\
\hline 13 & 22 & $M$ & $U G$ & 537 & $4 y$ & $10 y$ & none & & & 22 \\
\hline 14 & 23 & $\mathrm{~F}$ & PB & 547 & $4 y \& 6 m$ & $11 \mathrm{y}$ & none & & & 22 \\
\hline 15 & 26 & $\mathrm{~F}$ & PB & 540 & $5 y$ & $13 y$ & Canada & $1 \mathrm{~m}$ & travel & 23 \\
\hline 16 & 39 & $\mathrm{~F}$ & $U G$ & 560 & $4 y \& 4 m$ & $14 y$ & & $3 m$ & travel & 22 \\
\hline 17 & 23 & $\mathrm{~F}$ & PB & 565 & $1 \mathrm{y} \& 3 \mathrm{~m}$ & $11 y$ & USA & $1 \mathrm{~m}$ & study English & 23 \\
\hline 18 & 25 & $M$ & PB & & $5 y \& 6 m$ & $13 y$ & UK\&etc. & $1 \mathrm{w}$ & travel & 23 \\
\hline 19 & 27 & $\mathrm{~F}$ & $G R$ & 530 & $9 y$ & $15 y$ & Hong Kong & $1 w$ & travel & 29 \\
\hline 20 & 20 & $\mathrm{~F}$ & ESL & & $6 \mathrm{~m}$ & $9 y$ & USA \& etc. & $2 m$ & study English & 23 \\
\hline 21 & 20 & $\mathrm{~F}$ & ESL & & $6 \mathrm{~m}$ & $9 y$ & USA \& etc. & $3 w$ & travel & 22 \\
\hline 22 & 21 & $\mathrm{~F}$ & ESL & & $6 m$ & $8 y$ & USA & & & 15 \\
\hline 23 & 21 & $\mathrm{~F}$ & ESL & 450 & $6 \mathrm{~m}^{-1}$ & $8 y$ & Canada & $5 d$ & travel & 21 \\
\hline 24 & 21 & $F$ & ESL & & $6 \mathrm{~m}$ & $9 y$ & Canada & $1 w$ & travel & 28 \\
\hline 25 & 20 & $\mathrm{~F}$ & ESL & & $6 \mathrm{~m}$ & $11 \mathrm{y}$ & & & & 23 \\
\hline 26 & 20 & $\mathrm{~F}$ & ESL & & $7 m$ & $8 y$ & & & & 28 \\
\hline 27 & 20 & $F$ & ESL & & $6 \mathrm{~m}$ & $8 y$ & & & & 26 \\
\hline 28 & 22 & $\mathrm{~F}$ & ESL & 450 & $6 \mathrm{~m}$ & $12 y$ & USA & $10 d$ & study English & 28 \\
\hline 29 & 20 & $\mathrm{~F}$ & ESL & & $6 \mathrm{~m}$ & $10 y$ & Canada \& etc. & $2 w$ & travel & 23 \\
\hline 30 & 20 & $\mathrm{~F}$ & ESL & & $6 \mathrm{~m}$ & $8 y$ & & & & 27 \\
\hline 31 & 25 & $M$ & $G R$ & 543 & $1 y$ & $12 y$ & UK & $1 w$ & travel & 24 \\
\hline 32 & 26 & $\mathrm{~F}$ & $G R$ & 607 & $3 y$ & $13 y$ & Canada & $3 w$ & travel & 33 \\
\hline 33 & 20 & $\mathrm{~F}$ & ESL & 423 & $6 \mathrm{~m}$ & $8 y$ & Canada & $10 d$ & travel & 23 \\
\hline 34 & 26 & $M$ & GR & 557 & $1 \mathrm{y}$ & $13 y$ & Canada & $1 \mathrm{y} \& 6 \mathrm{~m}$ & study English & 24 \\
\hline 35 & 20 & $\mathrm{~F}$ & ESL & 400 & $7 \mathrm{~m}$ & $9 y$ & USA & $10 \mathrm{~d}$ & travel & 27 \\
\hline 36 & 41 & $\mathrm{~F}$ & $G$ & 613 & $4 m$ & $12 y$ & USA \& etc. & $1 \mathrm{y} \& 1 \mathrm{~m}$ & volunteer & 32 \\
\hline 37 & 21 & $\mathrm{~F}$ & UG & 550 & $1 \mathrm{~m}$ & $8 y$ & USA & $2 m$ & travel & 28 \\
\hline 38 & 26 & $\mathrm{~F}$ & $\mathrm{~PB}$ & 565 & $3 y$ & $14 y$ & USA & $2 m$ & travel & 23 \\
\hline 39 & 24 & M & $U G$ & & $3 y$ & $10 y$ & Canada & $2 w$ & travel & 28 \\
\hline 40 & 26 & $\mathrm{~F}$ & UG & 507 & $2 y$ & $8 y$ & Singapore & $1 w$ & travel & 24 \\
\hline 41 & 41 & $\mathrm{~F}$ & UG & & $5 y$ & $16 \mathrm{y}$ & & & & 25 \\
\hline 42 & 43 & $\mathrm{~F}$ & $G$ & 617 & $2 y$ & $10 y$ & UK & $1 \mathrm{~m}$ & travel & 29 \\
\hline 43 & 28 & $\mathrm{~F}$ & PB & 535 & $4 y \& 6 m$ & $14 \mathrm{y} \& 6 \mathrm{~m}$ & & & & 25 \\
\hline 44 & 35 & $F$ & PB & 550 & $5 y$ & $13 y$ & Canada & $10 d$ & travel & 26 \\
\hline 45 & 24 & $M$ & $\mathrm{~PB}$ & 513 & $2 y \& 6 m$ & $10 y$ & USA & $1 \mathrm{~m}$ & travel & 22 \\
\hline 46 & 27 & $F$ & $\mathrm{~PB}$ & 558 & $10 \mathrm{~m}$ & $15 y$ & USA & $2 y$ & study English & 24 \\
\hline 47 & 22 & $\mathrm{~F}$ & UG & 520 & $1 \mathrm{y} \& 6 \mathrm{~m}$ & $9 y$ & UK & $1 \mathrm{~m} \& 3 \mathrm{w}$ & study English & 18 \\
\hline 48 & 32 & $\mathrm{~F}$ & ESL & & $6 \mathrm{~m}$ & $8 y$ & UK & $2 w$ & travel & 34 \\
\hline 49 & 47 & $\mathrm{~F}$ & PB & 530 & $7 y$ & $11 y$ & USA \& etc. & $1 \mathrm{~m} \& 3 \mathrm{w}$ & travel & 33 \\
\hline 50 & 27 & $\mathrm{~F}$ & UG & 527 & $3 y$ & $9 y$ & & & & 24 \\
\hline 51 & 23 & M & UG & 523 & $5 y$ & $10 y$ & Canada & $1 w$ & travel & 26 \\
\hline
\end{tabular}




\begin{tabular}{|c|c|c|c|c|c|c|c|c|c|c|}
\hline Subject & Age & $\begin{array}{l}\text { Maler } \\
\text { Female }\end{array}$ & $\begin{array}{c}\text { Status in } \\
\text { School }\end{array}$ & TOEF & $\begin{array}{l}\text { Length of } \\
\text { Current } \\
\text { Residence }\end{array}$ & $\begin{array}{c}\text { Lenglh of } \\
\text { Studying } \\
\text { English }\end{array}$ & $\begin{array}{c}\text { Other Stay in } \\
\text { Eng-speaking } \\
\text { Countries }\end{array}$ & $\begin{array}{l}\text { Length } \\
\text { of the } \\
\text { Stay }\end{array}$ & $\begin{array}{l}\text { Purpose of } \\
\text { the Visit }\end{array}$ & $\begin{array}{c}\text { Test Score } \\
140\end{array}$ \\
\hline 52 & 23 & $M$ & UG & 523 & $1 \mathrm{y} \& 7 \mathrm{~m}$ & $8 y$ & Aus $\&$ etc. & $1 \mathrm{~m}$ & travel & 29 \\
\hline 53 & 31 & $M$ & PB & 577 & $2 m$ & $11 y$ & USA & $9 \mathrm{~m}$ & study English & 30 \\
\hline 54 & 23 & $\mathrm{~F}$ & UG & 585 & $5 y$ & $11 y$ & Aus. & $3 w$ & travel & 32 \\
\hline 55 & 24 & $F$ & UG & 590 & $3 y$ & $11 y$ & Aus. \& etc. & $2 m$ & travel & 28 \\
\hline 56 & 30 & $M$ & GR & 610 & $4 m$ & $14 y$ & USA & $1 \mathrm{y} \& 6 \mathrm{~m}$ & study English & 29 \\
\hline 57 & 21 & $M$ & UG & 527 & $1 \mathrm{y} \& 6 \mathrm{~m}$ & $9 y$ & none & & & 30 \\
\hline 58 & 22 & $\mathrm{~F}$ & UG & 530 & $3 y \& 6 m$ & $17 \mathrm{y} \& 6 \mathrm{~m}$ & Aus. \& etc. & $5 y \& 2 w$ & family & 31 \\
\hline 59 & 22 & $\mathrm{~F}$ & UG & 500 & $2 y$ & $10 y$ & Canada & $4 d$ & travel & 24 \\
\hline 60 & 23 & $M$ & Others & 460 & $2 y$ & $10 y$ & USA & $2 y$ & study English & 31 \\
\hline 61 & 22 & $M$ & UG & & $2 y \& 6 m$ & $9 y$ & Canada & $1 \mathrm{y} \& 10 \mathrm{~m}$ & study English & 29 \\
\hline 62 & 25 & $M$ & UG & 547 & $4 y$ & $13 y$ & Canada & $6 w$ & travel & 28 \\
\hline 63 & 22 & $F$ & $U G$ & 567 & $3 y \& 6 m$ & $7 y$ & USA \& etc. & $2 m$ & travel & 26 \\
\hline 64 & 25 & $M$ & GR & 620 & $6 y$ & $11 y$ & none & & & 27 \\
\hline 65 & 20 & $M$ & ESL & 507 & $1 \mathrm{~m}$ & $9 y$ & none & & & 26 \\
\hline 66 & 22 & $\mathrm{~F}$ & ESL & 493 & $2 m$ & $10 y$ & USA \& etc. & $1 \mathrm{~m} \& 1 \mathrm{w}$ & study English & 25 \\
\hline 67 & 20 & $\mathrm{~F}$ & ESL & 523 & $1 \mathrm{~m}$ & $7 y \& 6 m$ & USA & $1 y \& 2 m$ & study English & 29 \\
\hline 68 & 24 & $\mathrm{~F}$ & ESL & & $7 \mathrm{~m}$ & $12 y$ & USA & $9 m$ & study English & 27 \\
\hline 69 & 22 & $\mathrm{~F}$ & ESL & 500 & $2 y$ & $10 y$ & Aus. \& etc. & $1 \mathrm{~m}$ & travel & 33 \\
\hline 70 & 24 & $\mathrm{~F}$ & ESL & 500 & $1 \mathrm{y} \& 6 \mathrm{~m}$ & $12 y$ & Canada \& etc. & $1 \mathrm{~m}$ & study English & 28 \\
\hline 71 & 22 & $M$ & ESL & & $3 y$ & $9 y$ & & & & 24 \\
\hline 72 & 20 & $\mathrm{~F}$ & ESL & 493 & $1 y \& 3 \mathrm{~m}$ & $7 y$ & none & & & 25 \\
\hline 73 & 22 & $\mathrm{~F}$ & ESL & 517 & $3 m$ & $13 y$ & USA & $1 \mathrm{y} \& 7 \mathrm{~m}$ & study English & 29 \\
\hline 74 & 49 & $\mathrm{~F}$ & ESL & 517 & $5 \mathrm{~m}$ & $11 y$ & USA \& etc. & $2 m \& 1 w$ & travel & 22 \\
\hline & $\begin{array}{l}\text { Aver } \\
25.3\end{array}$ & $\begin{array}{l}\text { M: } 19 \\
F: 55\end{array}$ & $\begin{array}{l}\text { Lower } \\
\text { Advanced }\end{array}$ & $\begin{array}{c}\text { ESL: } 30 \\
\text { UG: } 23 \\
\text { PB: } 12 \\
\text { GR: } 8 \\
\text { Others: } 1\end{array}$ & $\begin{array}{l}\text { Range } \\
1 \mathrm{~m} \cdot 9 \mathrm{y}\end{array}$ & $\begin{array}{c}\text { Range } \\
7 y-21 y\end{array}$ & & \multicolumn{2}{|c|}{$\begin{array}{l}\text { Range } \\
3 d-5 y \& 2 w\end{array}$} & $\begin{array}{c}\text { Average } \\
25.91\end{array}$ \\
\hline
\end{tabular}


APPENDIX E

CORRECT, APPROPRIATELY WRONG AND WRONG RESPONSES BY SUBJECT GROUP 


\begin{tabular}{|c|c|c|c|c|c|c|c|c|}
\hline 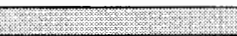 & 1 & 21 & 2 & 22 & 3. & 23 & 4 & 24 \\
\hline \multicolumn{9}{|l|}{ American } \\
\hline Correct & $30(96.8 \%)$ & $26(83.9 \%)$ & $25(80.6 \%)$ & $20(64.5 \%)$ & $27(87.1 \%)$ & $28(90.3 \%)$ & $19(61.3 \%)$ & $29(93.5 \%)$ \\
\hline Appropriately Wrong & $1 \quad(3.2 \%)$ & $0 \quad(0.0 \%)$ & $5(16.1 \%)$ & $10(32.3 \%)$ & $3 \quad(9.7 \%)$ & $3(9.7 \%)$ & $12(38.7 \%)$ & $2(6.5 \%)$ \\
\hline Wrong & $(0.0 \%)$ & $5(16.1 \%)$ & $(3.2 \%)$ & $(3.2 \%)$ & $(3.2 \%)$ & $(0.0 \%)$ & $0 \quad(0.0 \%)$ & $(0.0 \%)$ \\
\hline \multicolumn{9}{|l|}{ Advanced Level } \\
\hline Correct & $37(84.1 \%)$ & $40(90.9 \%)$ & $36(81.8 \%)$ & $31(70.5 \%)$ & $16(36.4 \%)$ & $37(84.1 \%)$ & $34(77.3 \%)$ & $32(72.7 \%)$ \\
\hline Appropriately Wrong & $(2.3 \%)$ & $(4.5 \%)$ & $5(11.4 \%)$ & $10(22.7 \%)$ & $19(43.2 \%)$ & $(6.8 \%)$ & $8(18.2 \%)$ & $9(20.5 \%)$ \\
\hline Wrong & $6(13.6 \%)$ & $(4.5 \%)$ & $3 \quad(6.8 \%)$ & $(6.8 \%)$ & $9(20.5 \%)$ & $(9.1 \%)$ & $(4.5 \%)$ & $3 \quad(6.8 \%)$ \\
\hline \multicolumn{9}{|l|}{ Lower Level } \\
\hline Correct & $27(90.0 \%)$ & $28(93.3 \%)$ & $21(70.0 \%)$ & $19(63.3 \%)$ & $7(23.3 \%)$ & $19(63.3 \%)$ & $17(56.7 \%)$ & $18(60.0 \%)$ \\
\hline Appropriately Wrong & $(6.7 \%)$ & $(0.0 \%)$ & $4(13.3 \%)$ & $8(26.7 \%)$ & $16(53.3 \%)$ & $5(16.7 \%)$ & $11(36.7 \%)$ & $8(26.7 \%)$ \\
\hline Wrong & $(3.3 \%)$ & $(6.7 \%)$ & $5(16.7 \%)$ & $3(10.0 \%)$ & $7 \quad(23.3 \%)$ & $6(20.0 \%)$ & $(6.7 \%)$ & $4(13.3 \%)$ \\
\hline
\end{tabular}

\begin{tabular}{|c|c|c|c|c|c|c|c|c|c|}
\hline 5 & 5 & 25 & 6 & 26 & 7 & & 27 & 8 & 28 \\
\hline \multicolumn{10}{|l|}{ American } \\
\hline Correct & $30(96.8 \%)$ & $29(93.5 \%)$ & $30(96.8 \%)$ & $30(96.8 \%)$ & $27(87.1 \%)$ & 31 & $(100 \%)$ & $30(96.8 \%)$ & $26(83.9 \%)$ \\
\hline Appropriately Wrong & $(3.2 \%)$ & $(0.0 \%)$ & $(0.0 \%)$ & $(0.0 \%)$ & $4(12.9 \%)$ & 0 & $(0.0 \%)$ & $1 \quad(3.2 \%)$ & $5(16.1 \%)$ \\
\hline Wrong & $(0.0 \%)$ & $(6.5 \%)$ & $(3.2 \%)$ & $(3.2 \%)$ & $0 \quad(0.0 \%)$ & 0 & $(0.0 \%)$ & $(0.0 \%)$ & $\begin{array}{ll}0 & (0.0 \%) \\
\end{array}$ \\
\hline \multicolumn{10}{|l|}{ Advanced Level } \\
\hline Correct & $33(75.0 \%)$ & $37(84.1 \%)$ & $13(29.5 \%)$ & $33(75.0 \%)$ & $5(11.4 \%)$ & 35 & $(79.5 \%)$ & $35(79.5 \%)$ & $25(56.8 \%)$ \\
\hline Appropriately Wrong & $8(18.2 \%)$ & $\begin{array}{ll}4 & (9.1 \%) \\
\end{array}$ & $15(34.1 \%)$ & $2 \quad(4.5 \%)$ & $34(77.3 \%)$ & 7 & $(15.9 \%)$ & $7(15.9 \%)$ & $16(36.4 \%)$ \\
\hline Wrong & $3 \quad(6.8 \%)$ & $(6.8 \%)$ & $16(36.4 \%)$ & $9(20.5 \%)$ & $5(11.4 \%)$ & 2 & $(4.5 \%)$ & $2 \quad(4.5 \%)$ & $(6.8 \%)$ \\
\hline \multicolumn{10}{|l|}{ Lower Level } \\
\hline Correct & $24(80.0 \%)$ & $27(90.0 \%)$ & $8(26.7 \%)$ & $26(86.7 \%)$ & $5(16.7 \%)$ & 19 & $(63.3 \%)$ & $24(80.0 \%)$ & $19(63.3 \%)$ \\
\hline Appropria & $3(10.0 \%)$ & $(6.7 \%)$ & $10(33.3 \%)$ & $(3.3 \%)$ & $23(76.7 \%)$ & 4 & $(13.3 \%)$ & $6(20.0 \%)$ & $9(30.0 \%)$ \\
\hline Wrong & $3(10.0 \%)$ & $(3.3 \%)$ & $12(40.0 \%)$ & $3(10.0 \%)$ & $(6.7 \%)$ & 7 & $(23.3 \%)$ & $(0.0 \%)$ & $(6.7 \%)$ \\
\hline
\end{tabular}

\begin{tabular}{|c|c|c|c|c|c|c|c|c|}
\hline rens: & 9 & 29 & 10 & 30 & 11 & 31 & 12 & 32 \\
\hline \multicolumn{9}{|l|}{ American } \\
\hline Correct & $30(96.8 \%)$ & $30(96.8 \%)$ & $19(61.3 \%)$ & $31(100 \%)$ & $31(100 \%)$ & $29(93.5 \%)$ & $23(74.2 \%)$ & $28(90.3 \%)$ \\
\hline Appropriately Wrong & $1 \quad(3.2 \%)$ & $1 \quad(3.2 \%)$ & $12(38.7 \%)$ & $0 \quad(0.0 \%)$ & $(0.0 \%)$ & $(0.0 \%)$ & $5(16.1 \%)$ & $(9.7 \%)$ \\
\hline Wrong & $(0.0 \%)$ & $0(0.0 \%)$ & $0 \quad(0.0 \%)$ & $(0.0 \%)$ & $(0.0 \%)$ & $(6.5 \%)$ & $3(9.7 \%)$ & $(0.0 \%)$ \\
\hline \multicolumn{9}{|l|}{ Advanced Level } \\
\hline Correct & $41(93.2 \%)$ & $35(79.5 \%)$ & $8(18.2 \%)$ & $29(65.9 \%)$ & $44(100 \%)$ & $44(100 \%)$ & $17(38.6 \%)$ & $30(68.2 \%)$ \\
\hline Appropriately Wrong & $(4.5 \%)$ & $8(18.2 \%)$ & $27(61.4 \%)$ & $(9.1 \%)$ & $(0.0 \%)$ & $(0.0 \%)$ & $18(40.9 \%)$ & $8(18.2 \%)$ \\
\hline Wrong & $(2.3 \%)$ & $1 \quad(2.3 \%)$ & $9(20.5 \%)$ & $11(25.0 \%)$ & $(0.0 \%)$ & $(0.0 \%)$ & $9(20.5 \%)$ & $6(13.6 \%)$ \\
\hline \multicolumn{9}{|l|}{ Lower Level } \\
\hline Correct & $26(86.7 \%)$ & $23(76.7 \%)$ & $8(26.7 \%)$ & $22(73.3 \%)$ & $27(90.0 \%)$ & $28(93.3 \%)$ & $13(43.3 \%)$ & $19(63.3 \%)$ \\
\hline Appropriately Wrong & $4(13.3 \%)$ & $5(16.7 \%)$ & $21(70.0 \%)$ & $3(10.0 \%)$ & $3(10.0 \%)$ & $(3.3 \%)$ & $5(16.7 \%)$ & $7(23.3 \%)$ \\
\hline Wrong & $0 \quad(0.0 \%)$ & $2 \quad(6.7 \%)$ & $1 \quad(3.3 \%)$ & $5(16.7 \%)$ & $0 \quad(0.0 \%)$ & $(3.3 \%)$ & $12(40.0 \%)$ & $4(13.3 \%)$ \\
\hline
\end{tabular}

\begin{tabular}{|c|c|c|c|c|c|c|c|c|}
\hline 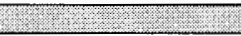 & 13 & 83 & 14 & 34 & 15 & 35 & 16 & 3.6 \\
\hline \multicolumn{9}{|l|}{ American } \\
\hline Correct & $22(71.0 \%)$ & $28(90.3 \%)$ & $19(61.3 \%)$ & $31(100 \%)$ & $17(54.8 \%)$ & $29(93.5 \%)$ & $24(77.4 \%)$ & $27(87.1 \%)$ \\
\hline Appropriately Wrong & $9(29.0 \%)$ & $2(6.5 \%)$ & $11(35.5 \%)$ & $(0.0 \%)$ & $14(45.2 \%)$ & $(0.0 \%)$ & $1 \quad(3.2 \%)$ & $0 \quad(0.0 \%)$ \\
\hline Wrong & $0 \quad(0.0 \%)$ & $1 \quad(3.2 \%)$ & $(3.2 \%)$ & $(0.0 \%)$ & $(0.0 \%)$ & $(6.5 \%)$ & $6(19.4 \%)$ & $4(12.9 \%)$ \\
\hline \multicolumn{9}{|l|}{ Advanced Level } \\
\hline Correct & $(6.8 \%)$ & $28(63.6 \%)$ & $6 \quad(14.0 \%)$ & $35(81.4 \%)$ & $13(29.5 \%)$ & $31(70.5 \%)$ & $23(52.3 \%)$ & $36(81.8 \%)$ \\
\hline Appropriately Wrong & $38(86.4 \%)$ & $9(20.5 \%)$ & $36(83.7 \%)$ & $3 \quad(7.0 \%)$ & $29(65.9 \%)$ & $(9.1 \%)$ & $13(29.5 \%)$ & $(6.8 \%)$ \\
\hline Wrong & $3 \quad(6.8 \%)$ & $7(15.9 \%)$ & $1 \quad(2.3 \%)$ & $5(11.6 \%)$ & $2 \quad(4.5 \%)$ & $9(20.5 \%)$ & $8(18.2 \%)$ & $5(11.4 \%)$ \\
\hline \multicolumn{9}{|l|}{ Lower Level } \\
\hline Correct & $8(26.7 \%)$ & $21(70.0 \%)$ & $7(23.3 \%)$ & $26(86.7 \%)$ & $13(43.3 \%)$ & $21(70.0 \%)$ & $15(50.0 \%)$ & $22(73.3 \%)$ \\
\hline Appropriately Wrong & $18(60.0 \%)$ & $5(16.7 \%)$ & $23(76.7 \%)$ & $3(10.0 \%)$ & $14(46.7 \%)$ & $1 \quad(3.3 \%)$ & $12(40.0 \%)$ & $3(10.0 \%)$ \\
\hline Wrong & $4(13.3 \%)$ & $4(13.3 \%)$ & $(0.0 \%)$ & $(3.3 \%)$ & $3(10.0 \%)$ & $8(26.7 \%)$ & $3(10.0 \%)$ & $5(16.7 \%)$ \\
\hline
\end{tabular}

\begin{tabular}{|c|c|c|c|c|c|c|c|c|c|c|}
\hline 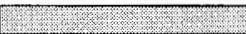 & 17 & 97 & & 18. & 88 & $=19$ & & 39 & 20 & 40 \\
\hline \multicolumn{11}{|l|}{ American } \\
\hline Correct & $23(74.2 \%)$ & $31 \quad(100 \%)$ & 18 & $(58.1 \%)$ & $16(51.6 \%)$ & $29(93.5 \%)$ & 31 & $(100 \%)$ & $30(96.8 \%)$ & $29(93.5 \%)$ \\
\hline Appropriately Wrong & $8(25.8 \%)$ & $0 \quad(0.0 \%)$ & 13 & $(41.9 \%)$ & $15(48.4 \%)$ & $1 \quad(3.2 \%)$ & 0 & $(0.0 \%)$ & $1 \quad(3.2 \%)$ & $2(6.5 \%)$ \\
\hline Wrong & $0 \quad(0.0 \%)$ & $0 \quad(0.0 \%)$ & 0 & $(0.0 \%)$ & $0 \quad(0.0 \%)$ & $(3.2 \%)$ & 0 & $(0.0 \%)$ & $(0.0 \%)$ & $(0.0 \%)$ \\
\hline \multicolumn{11}{|l|}{ Advanced Level } \\
\hline Correct & $17(38.6 \%)$ & $24(54.5 \%)$ & 23 & $(52.3 \%)$ & $21(47.7 \%)$ & $44(100 \%)$ & 43 & $(97.7 \%)$ & $37(84.1 \%)$ & $39<88$ \\
\hline Appropriately Wrong & $25(56.8 \%)$ & $15(34.1 \%)$ & 21 & $(47.7 \%)$ & $23(47.7 \%)$ & $0 \quad(0.0 \%)$ & 0 & $(0.0 \%)$ & $3 \quad(6.8 \%)$ & $4 \quad(9.1 \%)$ \\
\hline Wrong & $2 \quad(4.5 \%)$ & $5(11.4 \%)$ & 0 & $(0.0 \%)$ & $0 \quad(0.0 \%)$ & $(0.0 \%)$ & 1 & $(2.3 \%)$ & $(6.8 \%)$ & $(2.3 \%)$ \\
\hline \multicolumn{11}{|l|}{ Lower Level } \\
\hline Correct & $20(66.7 \%)$ & $14(46.7 \%)$ & 12 & $(40.0 \%)$ & $13(43.3 \%)$ & $26(86.7 \%)$ & 30 & $(100 \%)$ & $22(73.3 \%)$ & $23(76.7 \%)$ \\
\hline Appropriately Wrong & $9(30.0 \%)$ & $13(43.3 \%)$ & 17 & $(56.7 \%)$ & $16(53.3 \%)$ & $(6.7 \%)$ & 0 & $(0.0 \%)$ & $6(20.0 \%)$ & $5(16.7 \%)$ \\
\hline Wrong & $1 \quad(3.3 \%)$ & $3(10.0 \%)$ & 1 & $(3.3 \%)$ & $1 \quad(3.3 \%)$ & $(6.7 \%)$ & 0 & $(0.0 \%)$ & $2 \quad(6.7 \%)$ & $2 \quad(6.7 \%)$ \\
\hline
\end{tabular}

